\title{
ESTUDO FISIOLÓGICO COMPARADO DO DESENVOLVIMENTO E EFEITO DO ETHEPHON NA QUALIDADE TECNOLÓGICA DE QUATRO VARIEDADES DE CANA-DE-AÇÚCAR (Saccharum spp.)
}

\author{
MARCO ANTONIO FERREIRA PERENCIN \\ Engenheiro Agrônomo
}

Orientador: Prof. Dr. PAULO ROBERTO DE CAMARGO E CASTRO

Dissertação apresentada à Escola Superior de Agricultura "Luiz de Queiroz", da Universidade de São Paulo, para obtenção do título de Mestre em Ciências, Área de Concentração: Fisiologia e Bioquímica de Plantas.

PIRACICABA

Estado de São Paulo - Brasil

Janeiro/1996 
Dados Internacionais de Catalogação na Publicação (CIP) DIVISÃo DE BIBLIOTECA E DOCUMENTAÇÃO - Campus "Luiz de Queiroz"/USP

Perencin, Marco Antonio Ferreira

Estudo fisiológico comparado do desenvolvimento e efeito do ethephon na qualidade tecnológica de quatro variedades de cana-de-açúcar (Saccharum spp.) / Marco Antonio Ferreira Perencin. - Piracicaba, 1996.

110 p. : il.

Dissertação (mestrado) - - Escola Superior de Agricultura Luiz de Queiroz, 1996.

Bibliografia.

1. Cana-de-açúcar 2. Ethefon 3. Regulador de crescimento I. Título. 


\section{ESTUDO FISIOLÓGICO COMPARADO DO DESENVOLVIMENTO E EFEITO DO ETHEPHON NA QUALIDADE TECNOLÓGICA DE QUATRO VARIEDADES DE CANA-DE-AÇÚCAR (Saccharum spp.)}

MARCO ANTONIO FERREIRA PERENCIN

Aprovada em: 17/05/96

Comissão Julgadora:

Prof. Dr. Paulo Roberto de Camargo e Castro

ESALQ/USP

Prof. Dr. Marco Antonio de Azeredo César

ESALQ/USP

Prof. Dr. Otto Jesu Crocomo

ESALQ/USP

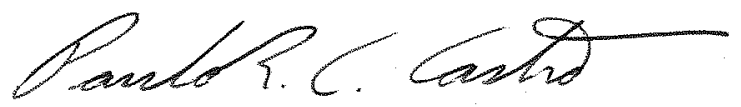

Prof. Dr. Paulo Roberto de Camargo e Castro

Orientador 
Ao meu pai Frederico Perencin Filho e a minha mãe

Maria Apparecida F. Perencin com gratidão

e reconhecimento por tudo que fizeram

no decorrer de minha vida.

A minha esposa Silvia Regina $M$. Perencin

e aos meus filhos Lucas e Felipe

pelo carinho e incentivo.

DEDICO. 


\section{AGRADECIMENTOS}

Ao Prof. Dr. Paulo Roberto de Camargo e Castro, pelo apoio, colaboração e valiosa orientação prestada.

Ao Prof. Dr. Otto Jesu Crocomo, pela amizade e incentivo recebidos.

Ao Prof. Dr. Quirino Augusto de Camargo Carmello, pela análise nutricional das variedades.

Ao Prof. Dr. Marco Antonio Azeredo César, pelas análises tecnológicas realizadas.

Ao Prof. Dr. Murilo de Melo pela colaboração na realização deste trabalho

Ao amigo João Chaddad Junior pela amizade e colaboração nas análises estatísticas.

A Maria Cristina Clemente Furlan pela amizade e incentivo recebidos.

Ao amigo Romeu Rocha pela elaboração de gráficos e figuras.

Aos funcionários do Departamento de Fisiologia Vegetal da Escola Superior de Agricultura "Luiz de Queiroz", pela colaboração na condução do experimento.

A todos que direta ou indiretamente, contribuíram para a realização deste trabalho. 


\section{ÍNDICE}

Página

RESUMO

SUMMARY

$\mathrm{xi}$

1. INTRODUÇÃO

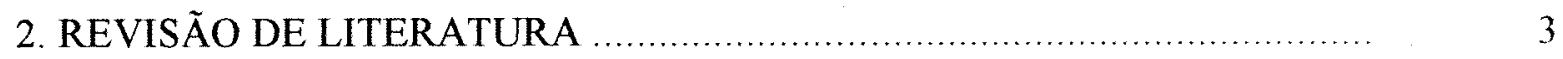

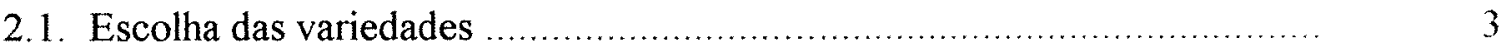

2.2. Crescimento da cana-de-açúcar ............................................... 5

2.3. Fatores que influenciam o crescimento das partes aéreas ...................... 6

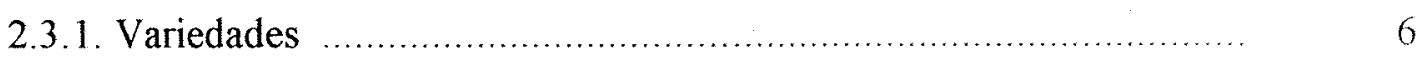

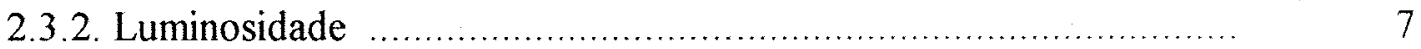

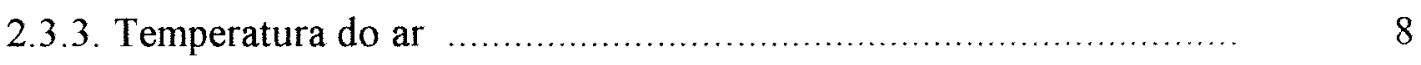

2.3.4. Umidade …...............................................................

2.3.5. Nutrientes

2.3.5.1. Nitrogênio .................................................. 11

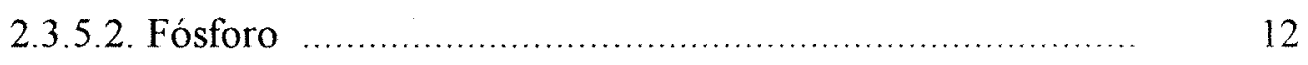

2.3.5.3. Potássio _......................................................... 13

2.3.5.4. Cálcio .............................................................. 15

2.3.5.5. Magnésio ........................................................ 16

2.3.5.6. Enxofre ....................................................... 17

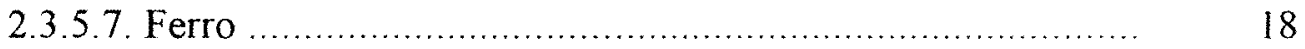

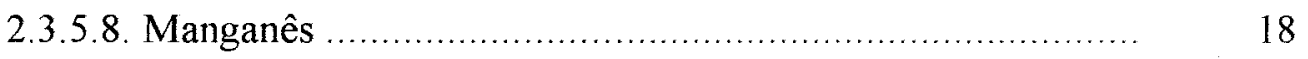

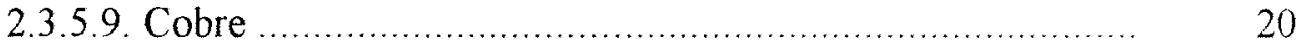

2.3.5.10. Zinco ........................................................ 19 


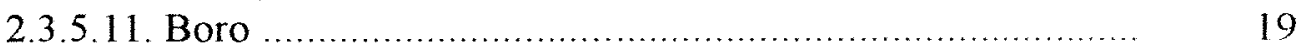

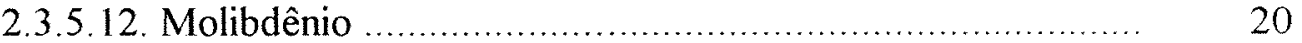

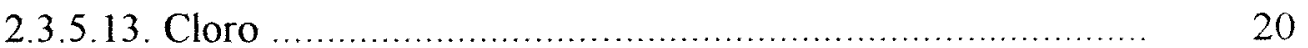

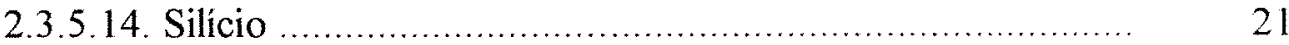

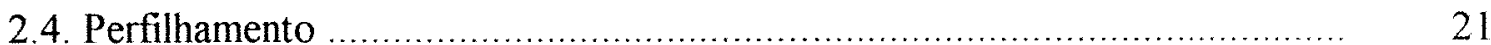

2.4.1. Modo de perfilhamento ......................................................... 22

2.4.2. Tendência do perfilhamento ................................................... 23

2.4.3. Diferença entre os rebentos ......................................................... 24

2.4.4. Fatores que influem no perfilhamento .......................................... 24

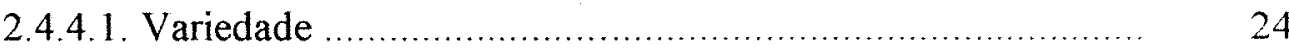

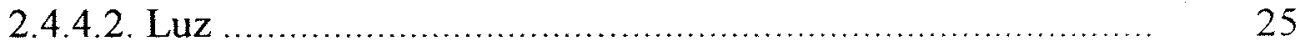

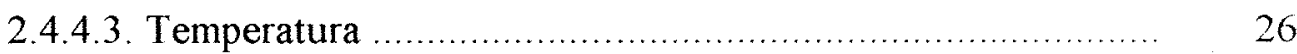

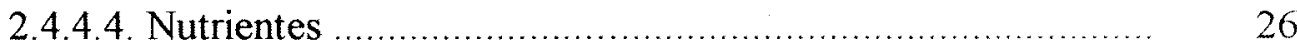

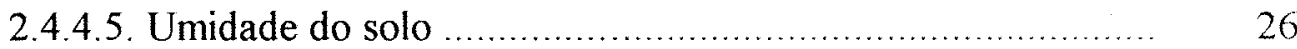

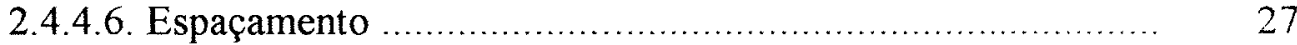

2.4.4.7. Cobertura da muda .................................................. 27

2.4.4.8. Época de plantio ...................................................... 28

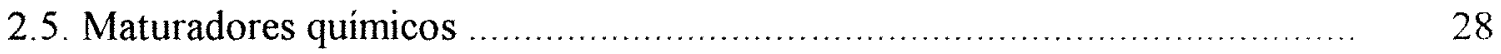

2.5.1. Efeitos do Ethephon no desenvolvimento da cana-de-açúcar .............. 30

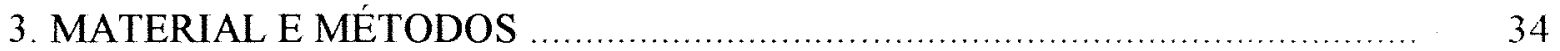

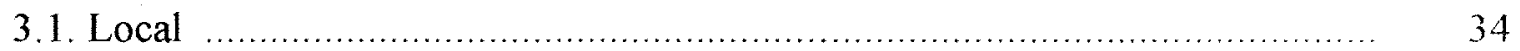

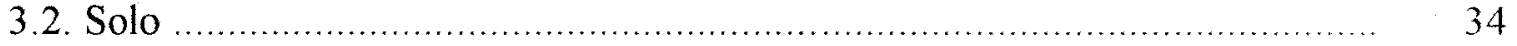

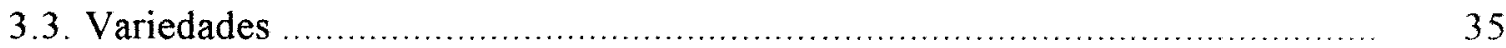

3.4. Instalação e condução dos experimentos ............................................ 37

3.5. Características agronômicas estudadas ................................................. 38

3.5.1. Altura das plantas .................................................................. 38 
3.5.2. Número de perfilhos …............................................... 38

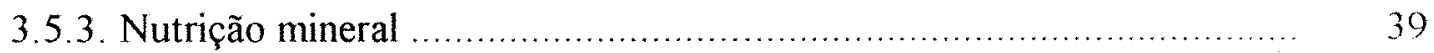

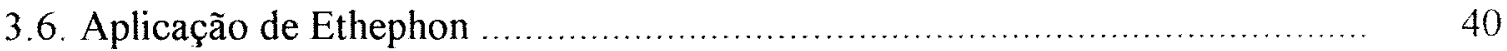

3.7. Características tecnológicas estudadas .......................................... 41

3.7.1. Fibra (\%) cana ......................................................... 41

3.7.2. Açúcares redutores (\%) cana (AR (\%) cana) ............................... 42

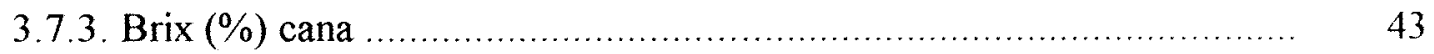

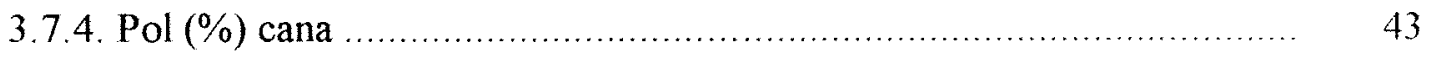

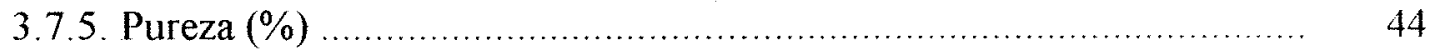

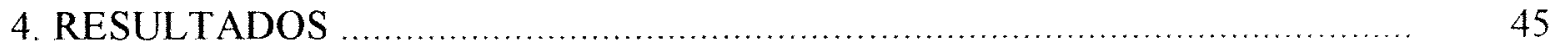

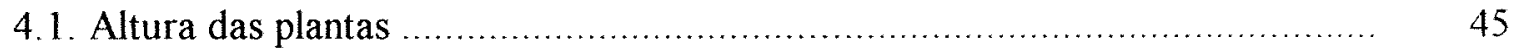

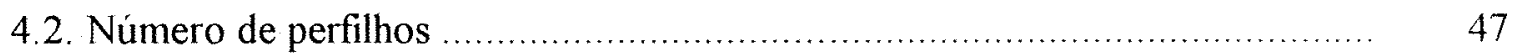

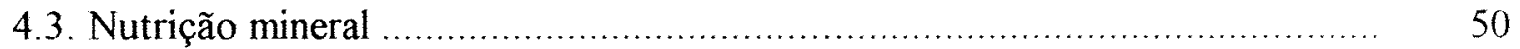

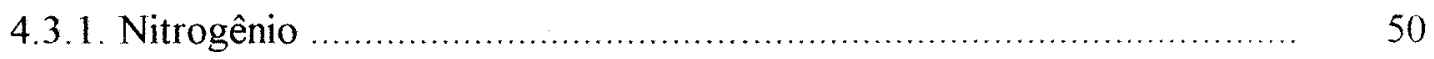

4.3.2. Fósforo …...................................................................... 51

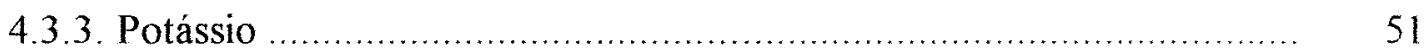

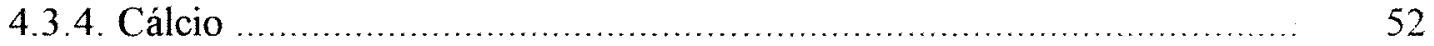

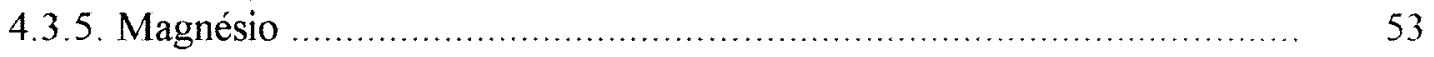

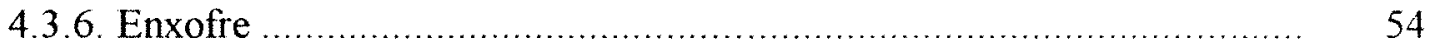

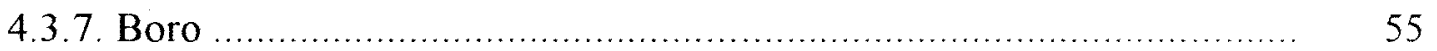

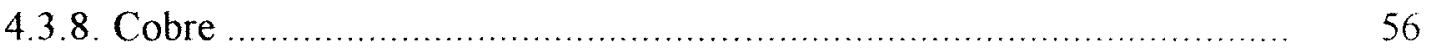

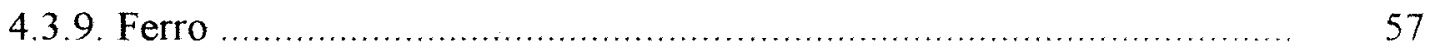

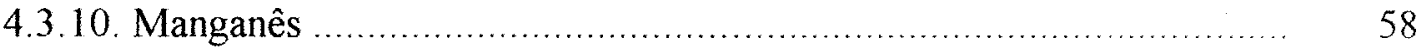

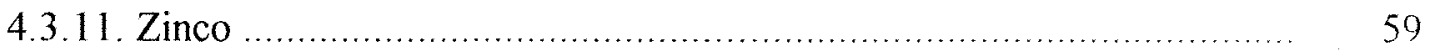




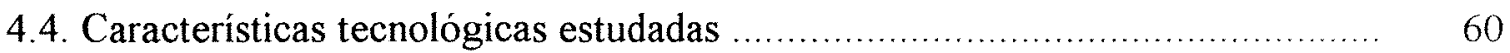

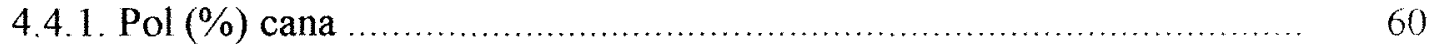

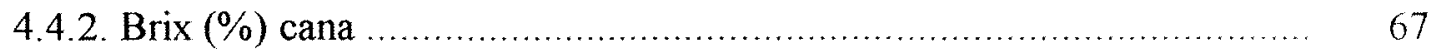

4.4.3. Açúcares Redutores (\%) Cana (AR \% cana) ................................ 69

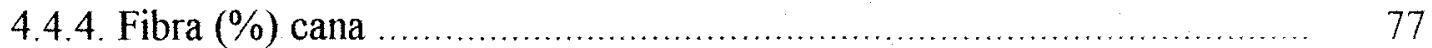

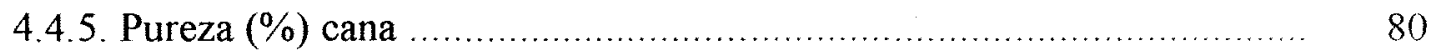

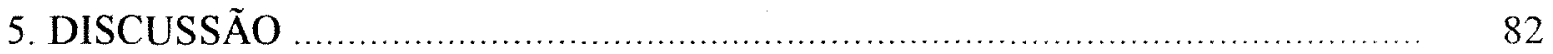

5.1. Altura das plantas ............................................................... 82

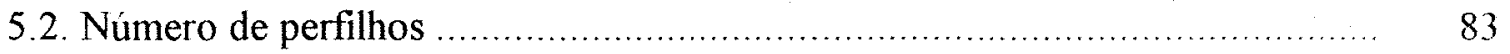

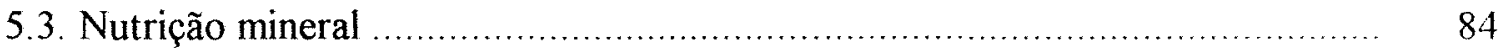

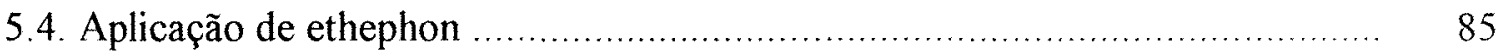

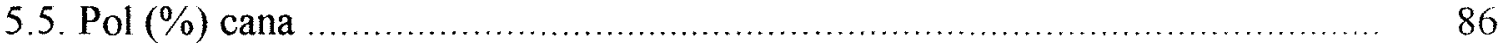

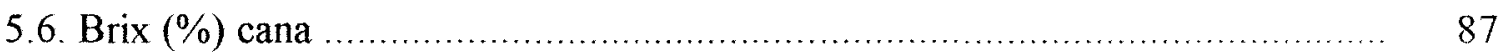

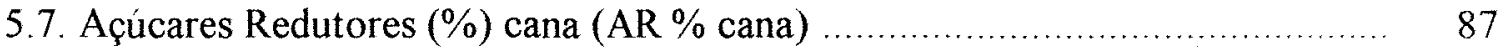

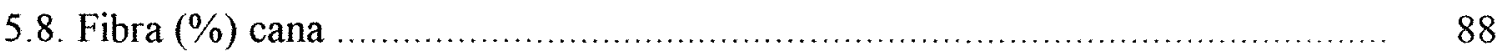

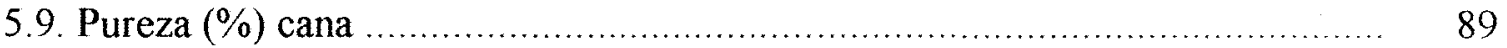

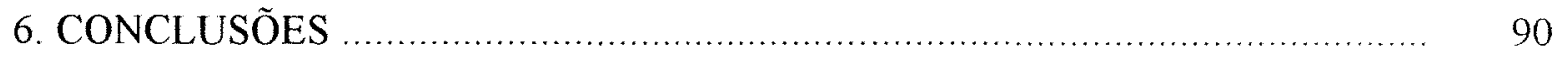

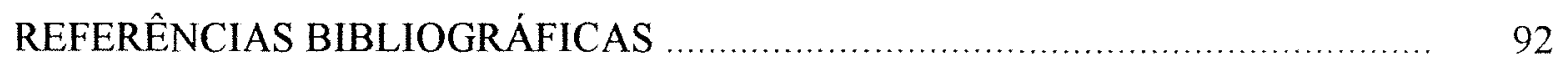

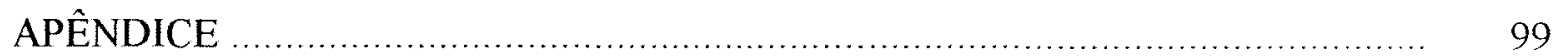




\title{
ESTUDO FISIOLÓGICO COMPARADO DO DESENVOLVIMENTO E EFEITO DO ETHEPHON NA QUALIDADE TECNOLÓGICA DE QUATRO VARIEDADES DE CANA-DE-AÇÚCAR (Saccharum spp.)
}

\author{
Autor: Marco Antonio Ferreira Perencin \\ Orientador: Prof. Dr. Paulo Roberto de Camargo e Castro
}

\section{RESUMO}

O presente trabalho teve por finalidade estudar o comportamento de quatro variedades de cana-de-açúcar (Saccharım spp.): SP 70-1143, SP 79-1011, RB 72454 e RB 76-5418, avaliando-se os aspectos relacionados ao desenvolvimento vegetativo, nutrição mineral e qualidade tecnológica das variedades em relação a utilização do regulador de crescimento ethephon (ácido 2-cloroetil fosfônico) durante a fase de maturação.

A pesquisa no campo foi realizada durante o periodo de janeiro de 1994 a julho de 1995, datas que equivalem as épocas de plantio e colheita, respectivamente, em Piracicaba, Estado de São Paulo.

Dentre as características agronômicas estudadas, determinou-se mensalmente a altura das plantas e o número de perfilhos para cada variedade estudada. Foi realizada também a análise nutricional foliar para cada uma das variedades.

Dentre as características tecnológicas estudadas, foram determinadas a Fibra $(\%)$ cana, açúcares redutores $(\%)$ cana, Brix $(\%)$ cana, Pol $(\%)$ cana e Pureza $(\%)$ cana em relação a aplicação ou não de ethephon. 
$\mathrm{O}$ maior desenvolvimento em altura foi verificado na variedade $\mathrm{RB}$ 76-5418, sendo que o perfilhamento mostrou-se mais eficiente na variedade SP 70-1143.

Observou-se uma maior exigência de nitrogênio durante o desenvolvimento inicial da cana-de-açúcar, sendo que notou-se maior assimilação de cálcio, magnésio e manganês na variedade RB 72-454.

De acordo com as variações nas características tecnológicas, observou-se que as variedades necessitam de diferentes intervalos de tempo para a resposta ao ethephon.

Os resultados mostraram que a variedade RB $72-454$ obteve melhores índices para pol (\%) cana aos 30 dias após a aplicação de ethephon, sendo que para a variedade SP 70-1143 os melhores resultados foram observados aos 60 dias após o tratamento.

Observou-se também que a variedade SP 70-1143 foi a que melhor respondeu ao ethephon, quanto as características tecnológicas estudadas. 


\title{
EFFECT OF ETHEPHON ON THE VEGETATIVE GROWTH, MINERAL NUTRITION AND INDUSTRIAL PROPERTIES ON FOUR VARIETIES OF SUGAR CANE (Saccharum spp.)
}

\author{
Author: Marco Antonio Ferreira Perencin \\ Advisor: Prof. Dr. Paulo Roberto de Camargo e Castro
}

\section{SUMMARY}

The objective of this work was to study the vegetative growth, nutrition mineral and industrial properties of four sugar cane varieties (Saccharum spp.): SP 70-1143, SP 79-1011, RB 72-454 and RB 76-5418, in relation to the effect of Ethephon (phosphonic 2-chloroethyl acid), a plant growth regulator.

The field work was carried out from January, 1994 to July, 1995; period of time corresponding to the sugar cane cycle at Piracicaba, São Paulo.

Among the vegetative growth parameters, the height and tillering of each variety were evaluated. Also the foliar mineral chemical composition was measured. In relation to the industrial properties, the fiber $(\%)$, reducing sugars $(\%)$, Brix $(\%)$, sugar $(\%)$ and purity $(\%)$ parameters were assayed. 
The RB 76-5418 variety showed the best vegetative growth and the SP 70-1143 variety the most efficient related to the number of shoot formation in presence of Ethephon treatment compared to the control.

Higher nitrogen requirement at the initial growth phase and higher absorption of calcium, magnesium and manganese were observed for the RB $72-454$ variety compared with all other varieties.

According to the variations in technological characteristics, it is observed that the varieties need different time to respond to Ethephon.

The results showed that the variety RB 72-454 demonstrated better index for Pol (\%) in sugarcane 30 days after application of Ethephon while for the variety SP 70-1143 better results was obtained 60 days after application.

Concerning to industrial properties the SP 70-1143 was the one showing the best response to Ethephon treatment. 


\title{
1. INTRODUÇÃO
}

\begin{abstract}
A cana-de-açúcar (Saccharum spp.) é uma das culturas de maior importância na atualidade, por ser matéria-prima na extração de produtos de grande importância sócio-econômica, como o açúcar e o álcool.
\end{abstract}

Historicamente, as pesquisas agrícolas têm sido voltadas principalmente para a obtenção de maiores incrementos na produção total da cultura, através do aprimoramento das técnicas agronômicas convencionais para se otimizar as produções. Atualmente, vem sendo incentivada a utilização de técnicas mais avançadas, tais como, melhoramento genético, aplicação de reguladores de crescimento, análise nutricional das plantas e mecanização da colheita.

Tendo em vista que centenas de híbridos de Saccharum spp. são cultivadas em todo o mundo e que muitas espécies existentes em bancos de germoplasma são utilizadas para hibridações, seria de grande importância que pesquisas fossem feitas para uma melhor distinção das variedades existentes. 
Visando atender aos interesses dos produtores que se utilizam do plantio da cana-de-açúcar, e tendo em vista facilitar a distinção das variedades pelos pesquisadores é que se justifica o presente trabalho.

A finalidade deste trabalho foi avaliar o comportamento de quatro variedades de cana-de-açúcar em plantio de cana de ano e meio, sob os aspectos de desenvolvimento vegetativo, nutrição mineral e a utilização de ethephon na fase de maturação.

A aplicação do ethephon (ácido 2-cloroetil fosfônico), se justifica, pelo fato deste produto químico evitar o florescimento em cana-de-açúcar, possibilitar antecipação da colheita por melhorar a qualidade do caldo através do aumento no teor de sacarose, além de estimular o perfilhamento.

O estudo do comportamento da cana-de-açúcar, em condições normais e sob o efeito de reguladores vegetais, pode trazer importantes esclarecimentos sobre a cultura. 


\section{REVISÃO DE LITERATURA}

\subsection{Escolha das variedades}

O período de industrialização de cana-de-açúcar é relativamente longo, exigindo a implantação de um conjunto de variedades para que, se racionalize não só a produção agrícola, mas também a industrial (PLANALSUCAR, 1986).

A escolha das variedades mais adequadas às áreas de produção e o manejo varietal indicado para o conjunto de cultivares escolhidos, constituem-se nos fatores menos dispendiosos e de maior retorno econômico da cultura, uma vez que o comportamento das variedades é observado considerando-se a influência do clima e do solo, além da tolerância às pragas e doenças (PLANALSUCAR, 1986).

De acordo com RESENDE et al. (1988), as variedades eleitas a ocupar significativa porção de área na lavoura devem satisfazer uma série mínima de requisitos exigidos tanto do ponto de vista agrícola como industrial, de modo a proporcionar à empresa otimização de seus recursos e maximização de sua lucratividade. 
Dentre as principais características exigidas das variedades de cana-deaçúcar sob o ponto de vista da área agrícola, REZENDE et al. (1988) citam:

- resistência econômica à doença;

- elevada produção de açúcar por unidade de área;

- longevidade de soqueiras;

- comportamento uniforme em diferentes safras;

- resistência econômica à pragas;

- ausência ou pouco florescimento;

- porte ereto;

- resistência ao acamamento;

- entre nó curto;

- fácil despalha;

- pouco joçal;

- fechamento rápido da entrelinha;

- tolerância à competição com plantas daninhas.

No que se refere as exigências industriais, RESENDE et al. (1988) relatam que o que se espera é uma variedade com características tecnológicas ótimas e estáveis durante a safra e nas diversas safras.

Dentre estas características, podem ser consideradas como as mais importantes o brix, a pol, a pureza, a fibra e o caldo extraido, todos expressos em valores porcentuais de cana. 


\subsection{Crescimento da cana-de-açúcar}

O crescimento, geralmente é considerado apenas uma alongação, mas no sentido mais amplo também abrange o aumento em diâmetro; o aumento em peso e o aumento da matéria seca também podem ser considerados como crescimento.

Esses fatores nem sempre ocorrem paralelamente. Por exemplo, durante uma seca a alongação pode cessar, ao passo que a assimilação e consequentemente, o aumento da matéria seca, pode continuar a crescer (ACCORSI, 1963).

A cana de ano e meio, plantada de janeiro ao inicio de abril, tem uma taxa de crescimento restrita, em função das condições climáticas, de maio a setembro.

Havendo boas condições de precipitação, a fase de maior desenvolvimento da cultura se processa de outubro a abril, com pico máximo de crescimento de dezembro a abril (ACCORSI, 1963).

Segundo MACHADO et al. (1982) o acúmulo de matéria seca possui três fases distintas no crescimento da cana-de-açúcar:

1) fase inicial de crescimento lento, entre o plantio e 200 dias após o plantio (março-outubro);

2) fase de crescimento rápido, entre 200-400 dias após o plantio, na qual 75\% da MS é acumulada (outubro-maio);

3) fase final, entre 400-500 dias após o plantio, onde o crescimento é novamente lento e responsável por $11 \%$ de toda a fitomassa (maio-agosto).

Segundo CAMARGO (1968), para o estudo do crescimento do colmo. é indispensável conhecer o sistema de Kuijper, para a medida da alongação 
Nesse sistema, os entrenós e as respectivas folhas são numeradas em ordem sucessiva, a partir do topo.

A primeira folha do fuso foliar que apresentar o colarinho perfeitamente visível, não encoberto pelos outros, levará o número +1 . O entrenó a que ela pertencer é o entrenó +1 . Por conseguinte, o nó desse entrenó é o nó +1 ; e o entreno imediatamente inferior é o entrenó +2 .

As folhas mais velhas, consecutivas, são designadas pelos números +2 ; $+3 ;+4$, etc, assim como os respectivos entrenós.

Durante o crescimento, à medida que as folhas mais novas emergem, a numeração é ajustada. Assim, a folha +1 passa a ser +2 , a folha zero passa a +1 .

O método usado para se estimar o crescimento da cana no campo, consiste em medir, periodicamente, a distância do colarinho +1 ao solo.

\subsection{Fatores que influenciam o crescimento das partes aéreas.}

Diversos fatores, internos e externos, influem no crescimento das partes aéreas da cana-de-açúcar. Os principais, são os seguintes:

\subsubsection{Variedades}

Com relação ao ciclo de maturação, ocorrem variedades de ciclo precoce, médio e tardio; este não pode, porém ser confundido com ciclo vegetativo, quando 
se tem por objetivo a produção de biomassa por área, ou seja, no início do período de safra, pode ocorrer que uma variedade precoce com relação à maturação venha produzir menos biomassa por área que uma variedade tardia (CASAGRANDE, 1991).

\subsubsection{Luminosidade}

Considerando-se que a cana-de-açúcar é uma planta de metabolismo $\mathrm{C}_{4}$, a alta eficiência fotossintética está condicionada a alta intensidade luminosa (CASAGRANDE, 1991).

Para CAMARGO (1968), em plena luz do sol, os colmos são mais grossos, porém mais curtos, as folhas são mais largas e mais verdes e o perfilhamento é mais intenso; em luz deficiente, os colmos são mais finos e longos, as folhas estreitas e amareladas.

O comprimento do dia também é importante, para BARBIERI (1981), em geral, o comprimento do colmo aumenta com o comprimento do dia variando de 10 a 14 horas, sendo, porém reduzido para fotoperíodos longos, entre 16 a 18 horas

Com relação ao número e formato das folhas, BULL \& GLASZIOU (1975) relatam que o número de folhas verdes varia de 6 a 12, com menos folhas sendo mantidas sob condições de seca e frio.

As folhas velhas, ao receberem baixa intensidade luminosa, tendem à senescência. 
As folhas verdes do topo são normalmente erectas, com o ápice curvo, e as demais podem ser mais ou menos erectas, dependendo da variedade e das condições de cultivo.

\subsubsection{Temperatura do ar}

Nas regiões sub-tropicais a temperatura é responsável por consideráveis flutuações no crescimento dos colmos. Em temperaturas nas quais o crescimento da cana-de-açúcar é lento ou nulo, ALFONSI et al. (1987) citam a informação de FAUCONIER (1975), de que em temperatura abaixo de $25^{\circ} \mathrm{C}$, o crescimento é lento.

Para BACCHI \& SOUZA (1978) o crescimento seria praticamente nulo a $19^{\circ} \mathrm{C}$, para culturas irrigadas e $18^{\circ} \mathrm{C}$ para as não irrigadas.

Próximas destes valores, temos as determinações de BARBIERI et al. (1979) que chegaram a $20^{\circ} \mathrm{C}$ para um crescimento praticamente nulo, e também a do PLANALSUCAR (1986), em que o cumprimento, diâmetro e o número de internódios aumentam significativamente, à medida que a temperatura média se eleva acima de $20^{\circ} \mathrm{C}$.

Com relação às temperaturas máximas, para Fauconier (1975), citado por ALFONSI et al. (1987), o crescimento seria lento acima de $35^{\circ} \mathrm{C}$ e praticamente nulo acima de $38^{\circ} \mathrm{C}$.

Segundo ALFONSI et al. (1987), a faixa ótima para a espécie estaria entre 20 e $35^{\circ} \mathrm{C}$, mas há que se citar também a relação com a radiação solar, principalmente nos primeiros estágios de desenvolvimento da cultura.

Para BULL \& GLASZIOU (1975), o prolongamento do desenvolvimento da fase juvenil, que ocorre sob baixas temperaturas, resulta da expansão 
relativa da razão de área foliar, que ocorre durante períodos de recepção de alta radiação solar.

\subsubsection{Umidade}

A necessidade de água pela cultura vai depender da planta, no que concerne à idade e área foliar; existe também uma diferença marcante entre os genótipos em cultivo, como foi observado por BRINHOLI (1975).

Existe uma relação entre a umidade do solo e a alongação do colmo. Contrariamente à expectativa, o colmo cresce em velocidade uniforme, desde que a umidade do solo esteja acima da porcentagem de murchamento. No ponto de murchamento, o crescimento cessa. No entanto, não faz diferença alguma que o solo esteja mais ou menos úmido (ACCORSI, 1963).

Enquanto a sua umidade estiver acima do ponto de murchamento, a velocidade do crescimento é uniforme. Isso, naturalmente, desde que não hajam outros fatores limitantes (ACCORSI, 1963).

\subsubsection{Nutrientes}

Segundo FERNANDES (1984), as necessidades minerais da cana-deaçúcar, são bastante altas com respeito ao $\mathrm{N}$ e K, e são seguidas em ordem decrescente pelo $\mathrm{Ca}, \mathrm{Mg}, \mathrm{S}$ e $\mathrm{P}$. 
A absorção desses nutrientes pela cana se dá normalmente pelo sistema radicular, embora as folhas possam absorver certa quantidade de nutrientes, quando esses são colocados em contato com elas. A absorção radicular é influenciada pela quantidade de água no solo, temperatura do mesmo, a erosão do solo, $\mathrm{pH}$, luminosidade, alta concentração de certos nutrientes, etc. Quanto mais próxima da capacidade de campo estiver a quantidade de água no solo, mais dinâmica será esta absorção (FERNANDES, 1984).

O poder de absorção cresce com a temperatura até um ótimo da ordem de 35 a $40^{\circ} \mathrm{C}$. O oxigênio é utilizado na respiração dos tecidos da raiz, que por sua vez fornece energia para o processo fisiológico da absorção de nutrientes (FERNANDES, 1984).

A absorção só se desenvolve na faixa que vai de $\mathrm{pH} 4,0$ até $\mathrm{pH} \mathrm{8,0}$. Quanto maior a atividade fotossintética, maior será a demanda de nutrientes, que forçará uma maior absorção.

Determinados nutrientes em quantidades superiores ao normal, prejudicam a absorção dos outros, como por exemplo, o aumento da quantidade de cálcio disponivel, diminui a absorção de ferro e de manganês, e que entre os dois há um certo antagonismo, pois o excesso de qualquer um deles provoca a deficiência do outro.

Além disso, dentro da própria cana há translocação de nutrientes de uma parte para outra. Os sintomas de deficiências de $\mathrm{N}, \mathrm{P}$ e $\mathrm{Mg}$, que são minerais bastante móveis, aparecem primeiro nas folhas mais velhas, isto porque as folhas mais jovens "retiram" esses nutrientes das folhas mais velhas (FERNANDES, 1984). 


\subsubsection{Nitrogênio}

As raizes dos vegetais utilizam o nitrogênio que chega até elas, através do processo de fluxo de massa. Como ocorre para a maioria das plantas, esse nutriente é absorvido principalmente como $\mathrm{NH}_{4}{ }^{+}$e $\mathrm{NO}_{3}{ }^{-}$, havendo predominância desta última forma (ALVAREZ, 1975). O nitrogênio, em quantidade, é o quarto nutriente presente na planta, vindo após o carbono, o hidrogênio e o oxigênio.

O nitrogênio aumenta o comprimento dos colmos da cana-de-açúcar, porém esse aumento faz com que a parede celular seja mais delgada, podendo ocorrer, em casos extremos, paredes tão finas, principalmente na parte central do colmo, que apresentam tendência de rompimento, indicando que o nutriente reduz a percentagem de fibras na planta (DAS, 1936).

Segundo CLEMENTS (1959), existe correlação entre o aumento do conteúdo de nitrogênio no solo e seu aumento no conteúdo das folhas e nos entrenós Quando a cana cresce em solução nutritiva, com elevados teores de nitrogênio, observa-se uma absorção em quantidade maior que a necessária, em comparação com canas que crescem em condições normais.

Está comprovado que a produtividade da cana aumenta com o incremento de doses de nitrogênio, porém essas canas apresentam maior conteúdo de umidade (INNES, 1959).

Ocorre marcante correlação positiva entre a absorção de nitrogênio e a umidade, de modo que as canas com bom suprimento de água e nitrogênio, sendo os demais 
fatores favoráveis, terão maior crescimento $\mathrm{e}$, até certo ponto, maior rendimento (ALVAREZ, 1975).

A relação entre teor de umidade na planta e o nitrogênio parece deverse principalmente ao fato de o nitrogênio favorecer a absorção do cálcio, que é um elemento plasmático por excelência e forma parte da parede celular, facilitando assim a absorção de água.

Segundo EPSTEIN (1975), o estudo do papel do nitrogênio quase se confunde com o da própria bioquímica das plantas. De acordo com diversos autores, compilados por MALAVOLTA (1976), cerca de 80 a $90 \%$ do nitrogênio absorvido passam para a forma orgânica, sendo, portanto, necessário que o nitrato seja reduzido a $\mathrm{NH}_{3}$, implicando a transferência de 8 elétrons. Esse processo de redução envolve a participação de uma enzima denominada redutase de nitrato, que contém fósforo, ferro e molibdênio

SINGH (1974), observou diminuição no teor de carboidratos, clorofila e na eficiência de assimilação de $\mathrm{CO}_{2}$ em cana-de-açúcar deficiente de nitrogênio

$\mathrm{O}$ principal efeito bioquímico da falta de nitrogênio é aquele que interfere com a síntese protéica. A inibição da síntese de clorofila resulta em uma clorose generalizada, ocorrendo assim diminuição na síntese de aminoácidos essenciais, além de afetar os processos de síntese de carboidratos e esqueletos carbônicos envolvidos nas sínteses orgânicas subseqüentes (EPSTEIN, 1975).

\subsubsection{Fósforo}

Segundo DILLEWIJN (1952), o maior conteúdo de fósforo na canade-açúcar ocorre nos centros de maior atividade da planta, tais como o de crescimento e o de assimilação de carbono. 
CLEMENTS (1955), apresentou a seguinte ordem decrescente de quantidades de fósforo na cana-de-açúcar: tecidos meristemáticos, colmos em alongação, folhas jovens, folhas velhas e cana madura. Assim, à medida que os tecidos aumentam de idade, apresentam quantidades menores de fósforo.

Praticamente todo o fósforo absorvido entra em contato com a raiz, através do processo de difusão. Esse nutriente geralmente é absorvido como $\mathrm{H}_{2} \mathrm{PO}_{4}^{-}$, sendo esta a forma predominante encontrada nos solos.

Direta ou indiretamente, esse nutriente participa de um número muito grande de processos metabólicos da vida da planta, tais como: armazenamento de energia (ADP e ATP), desdobramento de açúcares na respiração e fornecedor de energia a partir do ATP, apresentando-se como o composto-chave no metabolismo energético. A falta desse nutriente causa distúrbios severos e imediatos no metabolismo e no desenvolvimento das plantas.

HARTT \& BURR (1967) verificaram para cana-de-açúcar, que a deficiência em fósforo aos dois meses de idade diminui a atividade fotossintética mais que o nitrogênio ou o potássio. O fósforo tem importante participação na síntese de sacarose: glucose-1-fosfato + frutose $\rightarrow$ sacarose $+\mathrm{H}_{3} \mathrm{PO}_{4}$ (ALEXANDER, 1968)

\subsubsection{Potássio}

O potássio entra em contato com a raiz pelo processo de fluxo de massa, sendo absorvido como $\mathrm{K}^{+}$, que é móvel dentro da planta. O principal papel do potássio é o de ativador de numerosas enzimas (EPSTEIN, 1975). 
Segundo CLEMENTS (1959), esse nutriente serve para manter o protoplasma em dispersão e a estrutura celular, atuando também na assimilação do carbono e translocação de proteínas.

HARTT \& BURR (1967) observaram correlação positiva entre diminuição fotossintética e baixo teor de potássio nas folhas de cana-de-açúcar. As célulasguarda dos estômatos permanecem fechadas na falta de potássio, diminuindo a intensidade da fixação fotossintética de $\mathrm{CO}_{2}$.

HARTT (1933) verificou que em plantas deficientes em potássio ocorre aumento na percentagem de açúcares redutores e diminuição na de sacarose; que existem aumentos na atividade da invertase e amilase; que há aumento na taxa de respiração foliar; que ocorre diminuição da fotossíntese; que há redução no movimento da sacarose das folhas para os tecidos e diminuição da síntese e translocação de proteínas, devendo esta ser causada pela necrose do floema. Portanto, teores adequados do nutriente aumentam a sacarose na cana-de-açúcar (SCHECK, 1953).

HAUCH \& DICKINSON (1954) também demonstraram que em plantas deficientes de potássio a atividade hidrolítica da invertase é aumentada, acarretando, portanto, maior quantidade de açúcares redutores do que de sacarose.

Existe uma correlação positiva entre o conteúdo de potássio e o teor de umidade da cana, e de acordo com HUMBERT (1974) as plantas deficientes do nutriente perdem a turgescência foliar sendo, portanto, mais facilmente desfolhadas pelo vento.

Aumentos nos teores de nitrogênio, cálcio, magnésio, fósforo, silício, enxofre e ferro na cana-de-açúcar podem ser causados por deficiência de potássio 
(CLEMENTS et al., 1941). O aumento de nitrogênio por falta de potássio pode acarretar na morte de tecidos condutores e como conseqüência influir no transporte e na sintese de proteínas.

Segundo CLEMENTS (1959), a diminuição da produtividade das socas, em comparação com cana-planta, deve-se em alguns casos à falta de potássio, além do que o raquitismo das soqueiras pode estar associado à deficiência desse nutriente.

Plantas adequadamente supridas em potássio apresentam maior resistência às doenças devido ao fato de o potássio aumentar a espessura da cutícula (BARNES, 1964).

\subsubsection{Cálcio}

O cálcio é fundamental na composição salina do citoplasma, faz parte da parede celular em forma de pectato de cálcio, que dá estrutura às células e facilita a absorção de água por sua elevada função plasmolítica (ALVAREZ, 1959).

$\mathrm{O}$ cálcio é absorvido como íon $\mathrm{Ca}^{++}$, entrando em contato com as raizes através dos processos de fluxo de massa e interceptação radicular, com predominância do primeiro. O nutriente não se distribui dentro da planta, ou seja, é imóvel no floema. A despeito desse fato, em cana-de-açúcar os sintomas de deficiência se iniciam a partir das folhas mais velhas (ALVAREZ, 1959). 
Embora a deficiência de cálcio prejudique todos os pontos de crescimento, as raízes são as mais afetadas, tendo seu desenvolvimento retardado e adquirindo coloração escura, devido a um desarranjo na divisão mitótica (EPSTEIN, 1975).

ALEXANDER (1968) observou acúmulo de sacarose e diminuição na atividade da amilase em folhas de cana-de-açúcar deficientes em cálcio. HARTT \& BURR (1967) verificaram correlação positiva entre baixa taxa de fotossintese e baixo conteúdo de cálcio.

Quantidades excessivas de cálcio no solo aumentam a absorção de magnésio e reduzem grandemente a absorção de potássio (CLEMENTS, 1959).

\subsubsection{Magnésio}

O magnésio entra em contato com a raiz da planta da mesma forma que o cálcio: fluxo de massa e intercepção radicular, sendo absorvido como ion $\mathrm{Mg}^{++}$, apresentando mobilidade no floema.

Segundo ALVAREZ (1975), o magnésio é componente da molécula de clorofila, sendo entretanto encontrado em maior quantidade nos pontos de crescimento.

De acordo com EPSTEIN (1975), cerca de 2,7\% do peso molecular da clorofila são representados pelo magnésio. Peaslee \& Moss, citados por ALEXANDER (1968), verificaram que o efeito primário da deficiência de magnésio parece ser a deterioração da clorofila. 
O magnésio é ativador de muitas enzimas, principalmente aquelas ligadas ao metabolismo energético, tais como as respiratórias, de ativação de aminoácidos e descarboxilase (MALAVOLTA, 1976).

\subsubsection{Enxofre}

O enxofre atinge o sistema radicular principalmente através do processo de fluxo de massa, sendo absorvido na forma de $\mathrm{SO}_{4}^{-}$. Após a sua absorção, o mesmo é reduzido para ser incorporado em compostos orgânicos (THOMPSON, 1967). Pode também ser absorvido pelas folhas na forma de $\mathrm{SO}_{2}$.

Esse nutriente não se redistribui através do floema e xilema.

O enxofre é constituinte de numerosos compostos da planta, sendo as proteínas os mais importantes. Faz parte dos aminoácidos, tais como metionina e cistina, de reguladores de crescimento, que participam de reações de oxi-redução (JORDAN \& ENSMINGER, 1958).

Por ser constituinte das proteínas que entram na composição do protoplasma das plantas, a deficiência de enxofre provoca retardamento no crescimento (HUMBERT \& MARTIN, 1955).

Acredita-se, segundo Dutt, citado por HUMBERT (1974), que a deficiência de enxofre afeta o metabolismo de carboidratos da cana-de-açúcar. 


\subsubsection{Ferro}

O ferro é indispensável à síntese de clorofila e entra na composição de algumas proteínas envolvidas nos processos de oxidação (HUMBERT \& MARTIN, 1955).

A deficiência de ferro provoca o aparecimento de estrias amareladas ao longo de todo o limbo foliar. Mais tarde, toda a folha adquire um aspecto amarelado.

Em casos severos, as folhas novas ficam marcadamente cloróticas, as de idade intermediária ficam verde-pálidas e as mais velhas com a cor quase normal.

Há diminuição da parte aérea e do sistema radicular. As estrias cloróticas são internervais, paralelas ao longo da folha. Devido a ausência de raizes secundárias, resulta num sistema radicular curto e grosso (HUMBERT, 1974).

\subsubsection{Manganês}

O manganês funciona como ativador de enzimas nos processos de respiração e do metabolismo do nitrogênio. A deficiência do manganês faz com que as folhas mostrem faixas longitudinais bem distintas, verde-amareladas que só aparecem do meio da folha até a extremidade (FERNANDES, 1984).

\subsubsection{Cobre}

O cobre entra na composição de algumas enzimas, como as fenolases e lacases. A deficiência de cobre provoca clorose de moderada a severa, com o verde do 
limbo foliar dividido em pequenos retângulos que podem ser confundidos com o mosaico. As folhas ficam caídas como se tivessem sido quebradas. Há um alargamento anormal do limbo foliar e as folhas do cartucho podem deixar de abrir, podendo ocorrer a morte do ponteiro (FERNANDES, 1984).

\subsubsection{Zinco}

O zinco é ativador de várias enzimas e parece tomar parte no processo de sintese do acído indolilacético (AIA). A deficiência de zinco torna a nervura das folhas jovens cloróticas, aparecendo estrias não simétricas, cujo sintoma é mais acentuado na extremidade das folhas.

Ocorre excesso de folhas secas, redução do entrenó e crescimento retardado com o afinamento do palmito (FERNANDES, 1984).

\subsubsection{Boro}

O boro está ligado ao transporte de carboidratos no interior da cana. Atua na multiplicação e no crescimento celular e na formação das paredes celulares. A deficiência em boro provoca pequenas estrias cloróticas e aquosas no espaço internerval das folhas jovens, com o tecido necrosando-se no centro das lesões.

Tais folhas apresentam-se curtas e muito deformadas, com limbo foliar pregueado. Ocorre morte do meristema apical (FERNANDES, 1984). 


\subsubsection{Molibdênio}

O molibdênio faz parte de uma enzima que reduz o nitrato absorvido pelas raizes, permitindo assim a sua posterior transformação em amônia. A deficiência de molibdênio provoca pequenas estrias cloróticas de 1 a 3 milímetros de largura e com o comprimento variando de 1 milímetro até mais de 1 centímetro. Nas folhas mais velhas, formam-se com o tempo, centros roxos em tais estrias (FERNANDES, 1984).

\subsubsection{Cloro}

É atribuído ao cloro, importante papel na cisão fotossintética da água (fotólise) ao funcionar como protetor de alguma substância essencial àquele processo.

Os sintomas de deficiência quase não são descritos; em SOBRAL e WEBER (1983), descreve-se uma tendência do murchamento das plantas deficientes no nutriente, provavelmente devido a desarranjos nos processos respiratórios.

Todavia, mais que com os sintomas de deficiência, deve-se preocupar com o excesso de uso do $\mathrm{KCl}$ nas fórmulas de adubação. Para MALAVOLTA et al. (1989), os sintomas de excesso seriam: necrose nas extremidades e margens, amarelecimento prematuro e abscisão das folhas. 


\subsubsection{Sílicio}

Embora não seja incluído entre os elementos minerais considerados essenciais, plantas com baixos teores de silício têm produzido menor quantidade de açúcares e os sintomas de deficiência costumam aparecer nas folhas velhas, o que se caracteriza por "sardas foliares" (CHEONG et al., 1972).

\subsection{Perfilhamento}

Nas gramíneas, após o processo de brotação das gemas, os rebentos começam a formar outros rebentos, aos quais se denomina perfilhos; o processo é denominado perfilhamento.

Este processo está dividido em dois grupos: as que formam touceiras e as que formam capacho (DILLEWIJN, 1960).

Nas que formam touceiras, os rizomas ramificam-se durante um período limitado e logo produzem ramos verticais, que se desenvolvem em colmos, formando as touceiras (DILLEWIJN, 1960).

Neste caso, é fácil separar as plantas individuais.

Nas que formam capacho, a ramificação subterrânea é muito intensa. $\mathrm{O}$ solo é atravessado em todos os sentidos, por ramificações finas e raízes, de modo a formar um emaranhado que retém o solo em suas malhas, resultando dai uma massa compacta, que é o capacho da gramínea. 
Neste caso, não é fácil separar-se as plantas individuais. A este grupo pertencem as gramas em geral.

A cana-de-açúcar pertence ao grupo das formadoras de touceiras, com exceção da espécie Saccharum spontaneum, que é formadora de capacho (ROCHA, 1984).

Os rebentos podem crescer erectos ou então, esparramar-se, nos primeiros estágios do seu desenvolvimento, e depois dirigir-se para cima.

O hábito decumbente é, geralmente, um caráter varietal, mas pode ser induzido ou acentuado por condições externas. É o caso, por exemplo, dos toletes plantados muito rasos, em condições de sol intenso, alta temperatura e baixa umidade atmosférica. Os rebentos tendem a se espalhar, mesmo em variedades que não têm normalmente esse caráter (ROCHA, 1984).

\subsubsection{Modo de perfilhamento}

Os rebentos originários das gemas dos toletes são denominados de maternos ou primários.

Considerando que esses rebentos primários também possuem gemas e região radicular como os toletes, na parte subterrânea, essas gemas desenvolvem-se em novos rebentos, formando os rebentos secundários. Os rebentos originários dos secundários serão os terciários e assim por diante (DILLEWIJN, 1960).

O modo de perfilhamento varia de espécie para espécie e entre variedades, embora dentro das mesmas existam diferenças em função de diversos fatores. 
O perfilhamento é expresso por fórmulas que designam respectivamente o colmo primário e os secundários, terciários, etc. pelas letras sucessivas do alfabeto, com coeficientes indicativos dos números de rebentos (ROCHA, 1984).

A fórmula $P=a+3 b+3 c(P=$ perfilhamento $)$ representa o tipo mais simples de perfilhamento, das canas tropicais grossas, pertencendo a espécie Saccharum officinarum.

Próximo a este, vem o grupo das canas indianas (Saccharum barbieri) com a fórmula $\mathrm{P}=\mathrm{a}+9 \mathrm{~b}+7 \mathrm{c}$.

O mais intrincado é o perfilhamento de Saccharum spontaneum: $P=a+8 b+23 c+31 d+3 c$

A correlação negativa entre o diâmetro do colmo e o perfilhamento não é regra geral, mas é muito comum, principalmente dentro de cada grupo de canas.

Assim, as canas finas perfilham mais que as grossas.

\subsubsection{Tendência do perfilhamento}

Segundo ROCHA (1984), as variedades diferem grandemente em sua tendência de perfilhamento e no número final de colmos, na colheita. A maioria das gramíneas apresenta duas fases de desenvolvimento:
1) Fase de ramificação;
2) Fase de alongação. 
Durante a ramificação, o desenvolvimento da planta é limitado à formação de rebentos. Nesses períodos, a planta permanece com porte reduzido. Segue-se, então, a fase de alongação.

A cana-de-açúcar não segue essa norma. Não apresenta essas duas fases. Cada rebento, logo que se forma, já cresce, rapidamente, para cima, Somente em casos anormais é que ela permanece na fase de ramificação: doenças, plantio muito raso, combinado com ar seco e quente, etc. A tendência do perfilhamento é influenciado por fatores externos e internos (DILLEWIJN, 1960).

\subsubsection{Diferença entre os rebentos}

Os rebentos primários são mais finos e têm entrenós mais curtos. São mais direitos na base, ao passo que os de ordem elevada são recurvados na base, tem entrenós mais longos e são mais grossos (ROCHA, 1984).

\subsubsection{Fatores que influem no perfilhamento}

\subsubsection{Variedade}

O perfilhamento pode variar de variedade de cana-de-açúcar para variedade, dependendo das características genéticas de cada uma. Por exemplo, se uma variedade apresenta caracteres próximos da espécie $S$. officinarum, tem uma probabilidade 
de ser de baixo perfilhamento. O mesmo não aconteceria se os caracteres estivessem da $S$. spontaneum, havendo, neste caso, alto perfilhamento (CASAGRANDE, 1991).

\subsubsection{Luz}

A luz é um fator importantíssimo. Exerce o seu efeito de dois modos: pela intensidade e pela duração (fotoperiodismo) (ROCHA, 1984).

A baixa luminosidade diminui o perfilhamento. Canas que se desenvolvem na sombra não perfilham e, quando levados à luz intensa perfilham bastante.

CHRISTOFFOLETI (1986) relata que plantas de cana-de-açúcar provenientes de casa de vegetação com 56 dias de idade e plantadas no campo, sob condições de baixa luminosidade, tiveram praticamente todos os seus perfilhos mortos Porém, quando plantadas em condições normais de luminosidade, tiveram um processo normal de perfilhamento.

Segundo DILLEWIJN (1960), o perfilhamento é regulado pelas auxinas que são produzidas no ápice da planta, e descem, em fluxo contínuo, num gradiente.

Essas auxinas tem um efeito duplo, promovendo ao mesmo tempo a alongação do colmo e impedindo o desenvolvimento das gemas laterais.

Sob o efeito da alta intensidade luminosa, o fluxo de auxinas, do ápice para a base, será diminuido pela foto-destruição e consequentemente, haverá decréscimo no grau de inibição das gemas laterais, resultando daí a formação dos perfilhos. 
O perfilhamento é afetado pela duração da luz (fotoperíodo).

Sob dias curtos, ele é bem menor que em períodos de dias longos.

\subsubsection{Temperatura}

O perfilhamento aumenta, com a temperatura, até cerca de $30^{\circ} \mathrm{C}$.

Quando a temperatura é baixa, na época do perfilhamento, deve-se plantar mais raso, para que os efeitos positivos da luz contrabalancem os negativos da baixa temperatura (DILLEWIJN, 1960).

\subsubsection{Nutrientes}

Dentre os nutrientes minerais, os mais importantes para o perfilhamento são o nitrogênio e o fósforo.

De um modo geral, tem-se observado que, nos solos de baixa fertilidade, o perfilhamento tem sido menor (CASAGRANDE, 1991)

\subsubsection{Umidade do solo}

Uma umidade adequada do solo leva a um bom perfilhamento. Solos com baixa retenção de umidade estão mais sujeitos a auferir a cana-de-açúcar um baixo perfilhamento. 
Por outro lado, solos com excesso de umidade, mal drenados, também podem prejudicar o perfilhamento (CASAGRANDE, 1991).

\subsubsection{Espaçamento}

O espaçamento, nas linhas e entrelinhas influi no perfilhamento. Segundo DILLEWIJN (1960) a aproximação das touceiras e das linhas aumenta o perfilhamento e o número de colmos finais industrializáveis por área. Mas existe um espaçamento inter-linhas ótimo para cada variedade, no qual ela tem a máxima produtividade.

As variedades de baixo perfilhamento devem ser plantadas mais juntas. O espaçamento nas linhas depende do número de toletes na linha e do número de gemas por tolete.

No Brasil, os espaçamentos entre linhas mais utilizados, são de 1,40 $\mathrm{m}$ e $1,50 \mathrm{~m}$, sendo este último mais indicado para a colheita mecanizada.

Quanto ao número de gemas por metro linear de sulco, de 8-10 por metro passou-se a usar 12 gemas, com tendência a se passar até para 15 gemas.

\subsubsection{Cobertura da muda}

Segundo DILLEWIJN (1960), no caso de solos úmidos, pode-se apenas comprimir os toletes no solo deixando, inclusive, a parte superior visivel. Com isto, 
consegue-se um melhor perfilhamento, devido à melhor exposição dos rebentos primários, à luz e ao calor.

Portanto, no caso de haver boas condições de umidade, deve-se cobrir com uma pequena quantidade de terra os toletes, e o chegamento de terra, advindo do cultivo mecânico posterior, deve ser feito num estágio de cultura mais avançado, visando promover o desenvolvimento radicular dos rebentos e a formação de uma touceira mais vigorosa (DILLEWIJN, 1960).

\subsubsection{8. Época de plantio}

Em função das condições climáticas da região centro-sul do Brasil, o período de plantio pode ser de setembro a abril. Considerando que, de março em diante, teremos menores condições de luminosidade e calor, a cana-de-açúcar plantada neste período tende a ter um menor índice de perfilhamento (FERNANDES, 1984).

\subsection{Maturadores químicos}

Segundo FERNANDES (1984), a principal função dos maturadores químicos é a de interromper o desenvolvimento dos entrenós e folhas em formação, induzindo a planta a transformar, com mais intensidade, os seus açúcares redutores em sacarose, armazenando-a no colmo. 
Os diferentes maturadores químicos diferem entre si não só na formulação, como também no modo de aplicação e nas condições exigidas.

A quantidade do produto a ser aplicado deve ser tal que não chegue a matar a gema apical da cana, pois isso provocaria a brotação lateral e o apodrecimento dos entrenós superiores. A quantidade tem que ser o suficiente para interromper o crescimento vegetativo das partes ainda em formação, sem contudo provocar o crescimento das folhas adultas, pois, tal ocorrência provocaria a paralização dos processos metabólicos da planta, impedindo a formação de maiores quantidades de açúcar (FERNANDES, 1984).

Essas dosagens deverão ser testadas de acordo com as condições ambientais, pois o maturador químico é destinado a contrapor-se aos efeitos dos fatores favoráveis ao desenvolvimento vegetativo, que variam, de ano para ano.

De acordo com FERNANDES (1984), os maturadores químicos além do aumento no teor de sacarose, têm algumas vantagens interessantes e importantes, que são:

a) Nas variedades que florescem, a aplicação dos maturadores inibe o florescimento. Uma vez que inflorescência é a transformação da gema apical em panícula, e isto traz como conseqüência um consumo maior de energia (açúcares), não só para a formação de panícula, como também para a brotação das gemas laterais, tal inibição do florescimento é altamente providencial.

b) Os maturadores químicos conferem uma resistência ao tombamento, o que facilita sobremaneira o corte, diminuindo as perdas no campo e a quantidade de matéria estranha levada para a indústria. 
c) Devido ao enriquecimento do ponteiro e visto que as folhas da cana estão quase secas, ao se queimar o canavial, a cana poderá ser enviada para a indústria sem se fazer o desponte, conferindo mais peso por hectare, mais açúcar e maior economicidade e rapidez no corte das mesmas.

Quanto ao rendimento agrícola, visto que a cana poderá ser mandada para a indústria com o ponteiro, o acréscimo será altamente significativo, com quase $30 \%$ a mais na produção agrícola quando comparada com a mesma variedade que não recebeu o produto e necessitou a operação de desponte (FERNANDES, 1984).

Portanto, se o peso é maior e o teor de sacarose também é maior, a quantidade de açúcar ou de álcool produzido por hectare também serão maiores.

A dosagem a ser aplicada varia de produto para produto, e também com outros fatores já mencionados. Deverá ser feita mais ou menos 10 semanas antes da colheita e normalmente as aplicações são feitas por via aérea (FERNANDES, 1984).

\subsubsection{Efeitos do Ethephon no desenvolvimento da cana-de-açúcar}

Foi observado no Brasil, que a aplicação de ethephon entre meados de fevereiro até meados de março pode evitar florescência de numerosas variedades de canade-açúcar, inibindo o dreno da florescência e possibilitando maior disponibilidade de carboidratos para o dreno do parênquima do colmo (CASTRO, 1983). HUMBERT (1974) 
considerou o ethephon aplicado nas dosagens de 0,5 a $1,0 \mathrm{~kg} \cdot \mathrm{ha}^{-1}$, como um agente maturador com potencial para a utilização na cana-de-açúcar.

ROSTRON et al. (1976) verificaram a eficiência de ethephon no acúmulo precoce de sacarose, sob condições comerciais. Foi observado ainda, que o ethephon promove maior perfilhamento da soqueira da cana-de-açúcar (YANG \& PAO, 1974).

O ethephon, ácido (2-cloroetil) fosfônico é um produto químico mantido sob pH ácido, que libera etileno em contato com o tecido vegetal, o qual possui um $\mathrm{pH}$ mais elevado $(>3,5)$.

O mecanismo de ação do etileno (um hormônio gasoso existente no próprio tecido vegetal maduro) envolve sua ligação a um receptor protéico através de um processo reversível, por meio de forças de Van der Waals.

$\mathrm{O}$ receptor seria uma proteína rica em hidroxiprolina associada a membrana e a parede celular. $O$ etileno pode alterar a atividade da ATPase transportadora da membrana e aumenta a hidroxilação da prolina, incrementando peroxidase rica em hidroxiprolina na parede.

Pode atuar diretamente no bloqueio do metabolismo do DNA, retardando a alongação do entrenó.

Este processo pode ainda levar a sintese de um RNAm com suporte do respectivo RNAr, conduzindo à sintese de enzimas capazes de desencadear processos fisiológicos, relacionados com o perfilhamento, a florescência, maturação e senescência. 
Pesquisas recentes, têm demonstrado que o ethephon apresenta resultados promissores em cana-de-açúcar, pois tem sido eficiente para evitar o florescimento e consequentemente não formação de isopor (parênquima sem caldo), melhorar a qualidade do caldo, através do aumento no teor de sacarose e estimular o perfilhamento.

Esse regulador vegetal tem sido utilizado com sucesso no Brasil, Cuba, África do Sul e Rodésia, como agente maturador da cana-de-açúcar.

O processo de maturação da cana de açúcar envolve um sistema metabólico complexo que se inicia com a atividade fotossintética nos cloroplastos das células foliares, onde é produzida a triose-fosfato. Essa, através de uma série de reações, produz a sacarose, que migra até o vacúolo da célula.

O carboidrato produz hexose, que pode também originar sacarose. A sacarose é transportada da fonte através da parede celular e da célula companheira do floema, podendo sofrer carregamento ativo para o interior do tubo crivado.

Nessa via de transporte a sacarose se movimenta por fluxo de massa, até atingir a célula dreno, onde sofre descarregamento ativo para o interior do vacúolo de uma célula de parênquima no colmo.

Aplicações realizados por via aérea em algumas regiões do Estado de São Paulo, em meados de fevereiro de 1982, permitiram verificar que Ethrel na dosagem de 2 l.ha ${ }^{-1}$ evitou o florescimento da cana-de-açúcar tratada em safra excepcionalmente prejudicada pelo florescimento generalizado. 
Observou-se também que houve redução no crescimento do entrenó do colmo desenvolvido na época da pulverização, sendo que os entrenós formados posteriormente retomaram o crescimento normal.

Notou-se que, apesar das plantas mostrarem menores alturas, os colmos aproveitáveis atingiram uma maior proporção da planta, ocorrendo na colheita o descarte de uma menor região apical (palmito).

Verificou-se que as plantas tratadas com ethephon apresentaram uma menor proporção de parênquima sem caldo (isopor), mesmo quando ocasionalmente floresceram (CASTRO, 1983).

Observou-se ainda que a aplicação de ethephon promoveu maturação precoce de cana-de-açúcar. A falta de variedades produtivas com maturação precoce, pode ser contornada com a utilização de maturadores químicos para o suprimento da usina durante o ano todo. 


\section{MATERIAL E MÉTODOS}

\subsection{Local}

O presente trabalho foi desenvolvido em área do Departamento de Botânica da Escola Superior de Agricultura "Luiz de Queiroz", no município de PiracicabaSP.

\subsection{Solo}

O experimento foi instalado em solo classificado ao nivel de terra roxa estruturada durante o período de janeiro de 1994 a julho de 1995, os quais equivalem às épocas de plantio e colheita, respectivamente. 


\subsection{Variedades}

As mudas para o plantio foram fornecidas pela Usina Santa Bárbara, situada no município de Santa Bárbara D’Oeste, SP, sendo transplantadas em 14 de janeiro de 1994.

Foram estudadas quatro variedades de cana-de-açúcar: SP 79-1011, SP 70-1143, RB 72-454 e RB 76-5418, sob condições as mais uniformes possiveis (climáticas, edáficas e culturais), afastando-se desta forma, possíveis variações determinadas pelo meio.

Adotou-se o espaçamento convencional de 1,45 m entrelinhas.

As características agronômicas das variedades a serem utilizadas no presente trabalho são:

SP 70-1143

O rendimento agrícola é alto para todos os cortes e a riqueza em açúcar é média

O PUI (Período de Utilização Industrial) é curto e a maturação se dá de maneira precoce tendendo para mediana.

Possui ótima brotação de soqueiras e é pouco exigente em solos. 
A cana, floresce precoce e intensamente, ocorrendo rápida isoporização.

Perfilhamento da variedade SP 70-1143 é excelente (FERNANDES, 1984).

SP 79-1011

Maturação média, com alto teor de açúcar; não floresce, portanto não isoporiza. Possui ótima emergência e perfilhamento, boa produtividade de soqueira e é pouco exigente em solos.

O PUI (Período de Utilização Industrial) é longo, com alto rendimento agrícola (COPERSUCAR, 1991).

\section{RB 76-5418}

Riqueza em teor de açúcar.

Alta produção agrícola, não sendo muito exigente em fertilidade do solo.

Maturação precoce, não floresce, portanto não isoporiza. Possui boa emergência e perfilhamento regular, sendo indicada para solos médios à bons.

O PUI é longo, devido a excelente brotação no plantio e nas socas (GHELLE et al., 1990). 


\section{RB 72-454}

Alta produção agrícola, se mantém nos sucessivos cortes.

Alta capacidade de produção de açúcar quando cortada no período de meio para final de safra.

Possui maturação média à tardia, floresce raramente, boa germinação e bom perfilhamento, com alta produção agrícola.

Média exigência a fertilidade do solo.

PUI é longo, devido a excelente brotação das soqueiras (GHELLER et al., 1990).

\subsection{Instalação e condução dos experimentos}

Nos dias 10 e 11 de janeiro de 1994 promoveu-se à sulcação da área experimental à profundidade de $0,25 \mathrm{~m}$.

A adubação de plantio foi realizada no fundo dos sulcos antes da distribuição das mudas. Utilizou-se na adubação de plantio a fórmula fertilizante 05-20-20 à dosagem de $50 \mathrm{~g}$ por metro de sulco.

$\mathrm{Na}$ distribuição das mudas utilizou-se a densidade de 1 planta por metro de sulco, as quais, ao serem transplantadas, eram podadas em cerca de $50 \%$ da sua área foliar a fím de diminuir a transpiração da planta. 
Após o plantio efetuou-se o controle de plantas daninhas através da capina manual, sempre que necessário.

\subsection{Características agronômicas estudadas}

\subsubsection{Altura das plantas}

Foi medida com fita graduada em centímetros do nível do solo até o colarinho +1 , de acordo com o sistema KUIJPER, para a medida da alongação.

Durante o período compreendido entre 28/03/94 a 28/10/94, determinou-se mensalmente a altura das plantas.

O experimento foi instalado com delineamento experimental inteiramente casualizado, constando de 4 tratamentos (4 variedades) com 10 repetições. Os dados foram analisados pelo teste $\mathrm{F}$ e as médias comparadas pelo teste de Tukey, calculando-se a diferença mínima significativa ao nível de $5 \%$ de probabilidade

\subsubsection{Número de perfilhos}

Durante o período compreendido entre 28/03/94 a $28 / 10 / 94$, determinou-se mensalmente, através de contagem direta, o número de perfilhos para cada uma das variedades estudadas. 
O delineamento experimental utilizado foi inteiramente casualizado, constando de 4 tratamentos (4 variedades) com 10 repetições. Os dados foram analisados pelo teste $\mathrm{F}$ e as médias comparadas pelo teste de Tukey, calculando-se a diferença mínima significativa ao nível de $5 \%$ de probabilidade.

\subsubsection{Nutrição mineral}

Realizou-se a coleta das folhas em 01/11/94 para efetuar-se a análise química dos nutrientes minerais.

As amostras foram secas em estufa Fanem a $75^{\circ} \mathrm{C}$ até obtenção de peso constante.

Posteriormente encaminharam-se as amostras para análise química, após moagem e peneiragem em moinho de malha 20. O nitrogênio foi determinado por semi-micro KJELDAHL (MALAVOLTA, 1964), sendo que o fósforo foi determinado por colorimetria (LOTT et al., 1956). O potássio, cálcio e magnésio foram determinados por espectrofotometria de absorção atômica (SARRUGE \& HAAG, 1974), sendo que o enxofre foi dosado por gravimetria (CHAPMAN \& PRATT, 1973).

Os micronutrientes, boro, cobre, ferro, manganês e zinco foram determinados por espectrofotometria de absorção atômica (SARRUGE \& HAAG, 1974).

As análises química foram efetuadas no Departamento de Química da Escola Superior de Agricultura "Luiz de Queiroz". Realizaram-se as análises estatisticas para as porcentagens de $\mathrm{N}, \mathrm{P}, \mathrm{K}, \mathrm{Ca}, \mathrm{Mg}$ e $\mathrm{S}$ e para $\mathrm{B}, \mathrm{Cu}, \mathrm{Fe}, \mathrm{Mn}$ e $\mathrm{Zn}$, dados em ppm. 


\subsection{Aplicação de Ethephon}

A aplicação de ethephon foi realizada em 04/04/95, tendo-se pulverizado na concentração de $20 \mathrm{ml}$ de ethephon (Ethrel $240 \mathrm{~g} \cdot \mathrm{l}^{-1}$ ) para cada $10 \mathrm{I}$ de água. A solução continha também o espalhante adesivo Agral, na proporção de $0,3 \mathrm{ml} \cdot \mathrm{l}^{-1}$.

A pulverização das plantas foi efetuada com pulverizador manual, tendo sido utilizada uma escada de $3 \mathrm{~m}$ de altura para que as plantas fossem completamente molhadas.

Foi utilizada também uma barreira de plástico a fim de evitar que o ethephon atingisse as plantas testemunhas.

Os colmos eram cortados na base, desfolhados e amarrados em feixes de cinco colmos. A coleta dos colmos era feita mensalmente a partir da data da aplicação até a época da colheita, para a determinação das características tecnológicas desejadas.

O delineamento experimental utilizado foi o de parcelas sub-subdivididas inteiramente casualizado.

Foram estudados 3 fatores: variedades de cana-de-açúcar, aplicação de ethephon e meses; sendo que os dados foram analisados através do teste "F" e as médias comparadas pelo teste " $T$ ", calculando-se a diferença mínima significativa ao nível de $5 \%$ de probabilidade. 


\subsection{Características tecnológicas estudadas}

As características tecnológicas estudadas e descritas a seguir foram determinadas no Laboratório do Departamento de Ciência e Tecnologia Agroindustrial da ESALQ/USP.

As coletas das amostras foram realizadas em 08/05/95, 08/06/95 e 10/07/95, visando-se elaborar as curvas de maturação das variedades.

\subsubsection{Fibra (\%) cana}

A determinação dessa característica foi realizada segundo metodologia descrita em PLANALSUCAR (s.d.) aplicando-se a seguinte fórmula:

$$
F=\frac{100 \cdot P s-P u \cdot b}{5 .(100-b)}
$$

onde,

$\mathrm{F}=$ teor percentual de fibra presente na cana (Fibra (\%) cana);

Ps = peso do bolo seco;

$\mathrm{Pu}=$ peso do bolo úmido;

$\mathrm{b}=$ teor percentual de sólidos solúveis presentes no caldo extraido (Brix (\%) C.E.). 


\subsubsection{Açúcares redutores (\%) cana (AR (\%) cana)}

Para a determinação dos açúcares redutores no caldo, utilizou-se o método volumétrico de Lane \& Eynon (1934), citado por PLANALSUCAR (s.d.).

No cálculo aplicou-se a seguinte fórmula:

$$
Z=-\frac{Y}{d}
$$

onde,

$Z=$ teor percentual de açúcares redutores presentes no caldo extraído (AR (\%) CE);

$\mathrm{Y}=$ teor de açúcares redutores em $100 \mathrm{ml}$ de caldo;

$\mathrm{d}=$ densidade do caldo.

Para obtenção do teor percentual de açúcares redutores presentes na cana (AR (\%) cana), utilizou-se a seguinte fórmula:

$$
\text { A.R. }(\%) \text { cana }=Z(1-0,01 . F) . c
$$

onde,

$\mathrm{AR}(\%)$ cana $=$ teor percentual de açúcares redutores presentes na cana;

$Z=$ teor percentual de açúcares redutores presentes no caldo extraído (AR (\%) CE);

$\mathrm{F}=$ teor percentual de fibra presente na cana (Fibra $\%$ cana);

$\mathrm{c}=$ fator de transformação de caldo extraído para caldo absoluto. 
O fator de transformação (c) é determinado pela fórmula:

$$
c=1,0313-0,00575 . F
$$

\subsubsection{Brix (\%) cana}

O teor percentual de sólidos solúveis presentes na cana-de-açúcar foi calculado com base na determinação do teor percentual de sólidos solúveis presentes no caldo extraído, segundo metodologia descrita em PLANALSUCAR (s.d.).

fórmula:

Para efeito de cálculo do Brix (\%) cana, empregou-se a seguinte

$$
\operatorname{Brix}(\%) \text { cana }=\operatorname{Brix}(\%) C E \cdot(1-0,01, F) \cdot c
$$

onde,

Brix (\%) cana = teor percentual de sólidos solúveis nos colmos;

Brix (\%) $\mathrm{CE}=$ teor percentual de sólidos solúveis no caldo extraído determinado através de leitura direta no refratômetro;

$\mathrm{F}=$ teor percentual de fibra presente na cana (Fibra (\%) cana);

$\mathrm{c}=$ fator de transformação.

\subsubsection{Pol (\%) cana}

Após determinação da porcentagem em peso de sacarose aparente no caldo extraido, segundo metodologia descrita em PLANALSUCAR (s.d.), calculou-se a 
porcentagem em peso de sacarose aparente na cana-de-açúcar, de acordo com as fórmulas a seguir:

$$
\text { Pol }(\%) \mathrm{CE}=\frac{0,26.1}{\mathrm{~d}}
$$

onde,

Pol $(\%) \mathrm{CE}=$ porcentagem em peso de sacarose aparente no caldo extraído;

I = leitura do sacarímetro;

$\mathrm{d}=$ densidade do caldo obtida em função do Brix.

$$
\text { Pol }(\%) \text { cana }=\text { Pol }(\%) \text { CE }(1-0,01 . F) . c
$$

onde,

Pol $(\%)$ cana $=$ porcentagem em peso de sacarose aparente nos colmos;

Pol $(\%) \mathrm{CE}=$ porcentagem em peso de sacarose aparente no caldo extraido;

$\mathrm{F}=$ teor percentual de fibra na cana;

$\mathrm{c}=$ fator de transformação.

\subsubsection{Pureza (\%)}

A pureza percentual foi calculada através da relação entre a porcentagem em peso de sacarose aparente nos colmos (Pol (\%) cana) e teor percentual de sólidos solúveis presentes na cana (Brix (\%) cana), conforme a expressão dada a seguir:

$$
\text { Pureza }=\frac{\text { Pol }(\%) \text { cana }}{\text { Brix }(\%) \text { cana }}
$$




\section{RESULTADOS}

\subsection{Altura das plantas}

A análise de variância para altura das plantas revelou valores de $\mathrm{F}$ significativos ao nível de $1 \%$ de probabilidade em todas as variáveis observadas.

Os dados apresentados na Tabela 1 mostram diferenças significativas para altura das plantas durante o período de avaliação (28/03/94 a 28/10/94).

Com relação às variedades, os dados apresentados na Tabela 1 mostram a superioridade em altura das plantas da variedade RB $76-5418$ em relação as demais, RB 72-454, SP 79-1011 e SP 70-1143.

Através da Figura 1, observou-se que por meio das mensurações mensais da altura das variedades, as diferenças em altura entre os meses são bem nítidas. 
Tabela 1. Mensurações mensais da altura total $(\mathrm{cm})$ das variedades de cana-de-açúcar estudadas, realizadas no período de 28/03/94 à 28/10/94. Médias de 10 repetições.

\begin{tabular}{lcccccccc}
\hline & \multicolumn{7}{c}{ Altura da planta (cm) } \\
\cline { 2 - 8 } Variedades & Março & Abril & Maio & Junho & Julho & Agosto & Setembro & Outubro \\
\hline RB 76-5418 & $46,45 \mathrm{a}$ & $99,20 \mathrm{a}$ & $139,20 \mathrm{a}$ & $140,10 \mathrm{a}$ & $144,40 \mathrm{a}$ & $150,40 \mathrm{a}$ & $154,20 \mathrm{a}$ & $169,90 \mathrm{a}$ \\
RB 72-454 & $41,10 \mathrm{a}$ & $81,60 \mathrm{~b}$ & $116,00 \mathrm{~b}$ & $118,60 \mathrm{~b}$ & $123,70 \mathrm{~b}$ & $128,70 \mathrm{~b}$ & $131,00 \mathrm{~b}$ & $139,40 \mathrm{~b}$ \\
SP 79-1011 & $29,80 \mathrm{~b}$ & $69,60 \mathrm{c}$ & $99,20 \mathrm{c}$ & $100,90 \mathrm{c}$ & $107,90 \mathrm{c}$ & $117,00 \mathrm{c}$ & $119,60 \mathrm{c}$ & $134,00 \mathrm{~b}$ \\
SP 70-1143 & $29,17 \mathrm{~b}$ & $54,50 \mathrm{~d}$ & $54,50 \mathrm{~d}$ & $81,20 \mathrm{~d}$ & $85,00 \mathrm{~d}$ & $90,50 \mathrm{~d}$ & $94,50 \mathrm{~d}$ & $114,40 \mathrm{c}$ \\
\hline F (trat.) $=5,54^{* *}$ & & & & & & & & \\
D.M.S. Tukey $(5 \%)=10,69$ & & & & & & & & \\
C.V. $(\%)=9,18$ & & & & & & & & \\
\hline
\end{tabular}

Médias seguidas por letras distintas diferem entre si ao nível mínimo de significância de $5 \%$ de probabilidade.

** Significativo ao nível de $1 \%$ de probabilidade. 


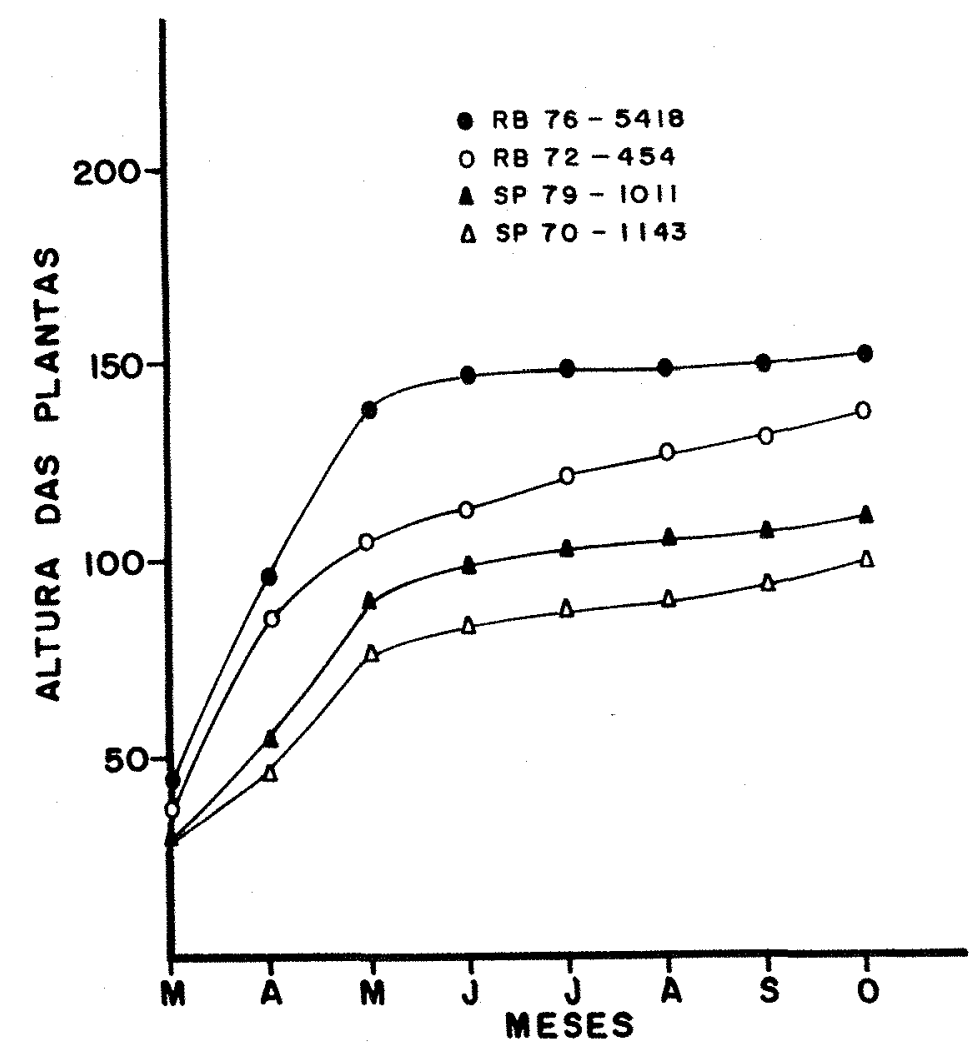

Figura 1. Mensurações mensais da altura das plantas $(\mathrm{cm})$, realizadas durante o período de 28/03/94 à 28/10/94.

\subsection{Número de perfilhos}

Para o número de perfilhos, a análise de variância indicou valores de $\mathrm{F}$ significativos ao nível de $1 \%$ de probabilidade para a interação entre variedades e meses.

Os valores médios obtidos para essa característica são apresentadas na Tabela 2. 
Tabela 2. Contagens diretas do número de perfilhos das variedades de cana-de-açúcar estudadas, realizadas no período de 28/03/94 à 28/10/94. Médias de 10 repetições.

\begin{tabular}{|c|c|c|c|c|c|c|c|c|}
\hline \multirow[b]{2}{*}{ Variedades } & \multicolumn{8}{|c|}{ Número de perfilhos } \\
\hline & Março & Abril & Maio & Junho & Julho & Agosto & Setembro & Outubro \\
\hline SP $70-1143$ & $7,80 \mathrm{a}$ & $15,90 \mathrm{a}$ & $17,30 \mathrm{a}$ & $17,50 \mathrm{a}$ & $17,50 \mathrm{a}$ & $17,50 \mathrm{a}$ & $17,50 \mathrm{a}$ & $17,50 \mathrm{a}$ \\
\hline SP 79-1011 & $6,10 a b$ & $10,90 \mathrm{~b}$ & $11,90 \mathrm{~b}$ & $11,90 \mathrm{~b}$ & $11,90 \mathrm{~b}$ & $11,90 \mathrm{~b}$ & $11,90 \mathrm{~b}$ & $12,50 \mathrm{~b}$ \\
\hline RB 76-5418 & $3,90 \mathrm{bc}$ & $6,00 \mathrm{c}$ & $7,80 \mathrm{c}$ & $8,10 \mathrm{c}$ & $10,80 \mathrm{~b}$ & $10,80 \mathrm{~b}$ & $10,80 \mathrm{~b}$ & $10,80 \mathrm{~b}$ \\
\hline RB 72-454 & $3,40 \mathrm{c}$ & $5,80 \mathrm{c}$ & $7,60 \mathrm{c}$ & $7,80 \mathrm{c}$ & $7,80 \mathrm{c}$ & $7,80 \mathrm{c}$ & $7,80 \mathrm{c}$ & $7,80 \mathrm{c}$ \\
\hline \multicolumn{9}{|c|}{$\mathrm{F}($ trat $)=2,32^{* *}$} \\
\hline \multicolumn{9}{|c|}{ D.M.S. Tukey $(5 \%)=2,68$} \\
\hline \multicolumn{9}{|c|}{ C.V. $(\%)=22,13$} \\
\hline
\end{tabular}

Médias seguidas por letras distintas diferem entre si ao nível mínimo de significância de $5 \%$ de probabilidade.

** Significativo ao nível de $1 \%$ de probabilidade. 
Com relação as variedades de cana-de-açúcar estudadas, observou-se que a variedade SP 70-1143 foi a que obteve o melhor perfilhamento.

Nota-se através da Tabela 2 que, as variedades SP 79-1011 e RB 76-5418 embora não tenham sido estatisticamente diferentes, a variedade SP 79-1011 tendeu a ser numericamente superior. Durante o período de avaliação, a variedade RB 72454 mostrou-se inferior as demais variedades quanto ao número de perfilhos.

Verificou-se pela observação da Figura 2, que inicialmente quase não houve diferença de perfilhamento entre as variedades RB 76-5418 e RB 72-454, mas no final da avaliação, a variedade RB 76-5418 mostrou-se superior a RB 72-454.

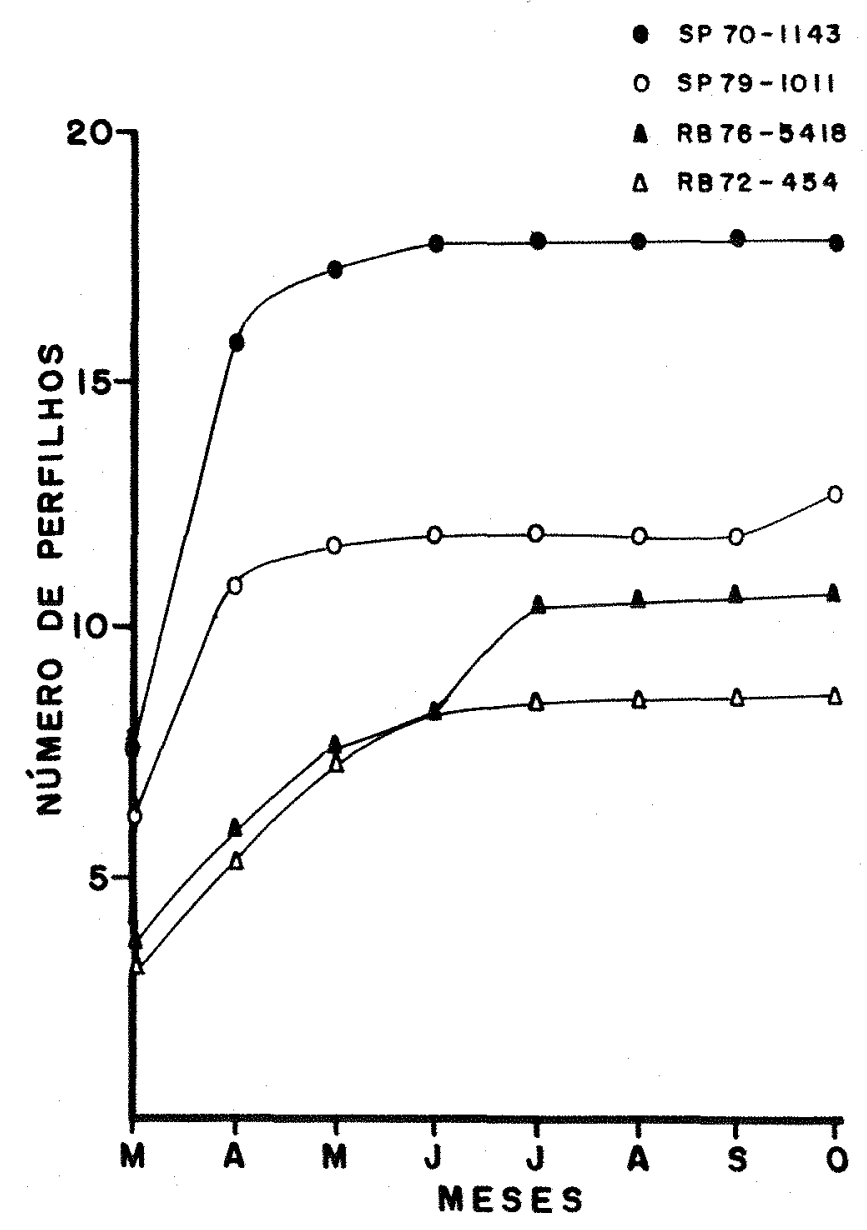

Figura 2. Contagens diretas do número de perfilhos das variedades estudadas, realizadas no período de 28/03/94 à 28/11/94. 
Com relação aos meses, notou-se pela Tabela 2 , que durante os meses de maio a setembro de 94 , o número de perfilhos das variedades testadas praticamente não variou.

\subsection{Nutrição mineral}

\subsubsection{Nitrogênio}

A análise de variância para o macronutriente nitrogênio nas variedades testadas indicou valor de $\mathrm{F}$ não significativo a $5 \%$ de probabilidade.

Isto mostrou que não houve diferença significativa em relação à assimilação de nitrogênio entre as variedades testadas (Tabela 3).

Nota-se através das médias da Tabela 3 que a variedade RB 72-454 embora não tenha sido estatisticamente diferente das demais, tendeu a ser numericamente superior em relação à porcentagem de nitrogênio assimilado.

Tabela 3. Comparação das médias (em \%) para o macronutriente nitrogênio, entre as variedades testadas. Médias de 6 repetições.

\begin{tabular}{ccc}
\hline Elemento & Variedade & Médias \\
\hline $\mathrm{N}$ & RB 72-454 & $1,22 \mathrm{a}$ \\
& SP 79-1011 & $1,13 \mathrm{a}$ \\
& RB 76-5418 & $1,10 \mathrm{a}$ \\
& SP 70-1143 & $1,02 \mathrm{a}$ \\
\hline
\end{tabular}

$\mathrm{F}$ (trat. $)=2,98$ n.s.

D.M.S. Tukey $(5 \%)=0,19$

C.V. $(\%)=10,35$

Médias seguidas por letras distintas diferem entre si ao nível mínimo de significância de $5 \%$ de probabilidade.

n.s. Não significativo. 


\subsubsection{Fósforo}

A análise de variância para o macronutriente fósforo nas variedades testadas indicou valor de $\mathrm{F}$ não significativo a $5 \%$ de probabilidade.

Isto mostrou que não houve diferença significativa em relação à assimilação de fósforo entre as variedades testadas (Tabela 4).

Nota-se através das médias da Tabela 4 que, as variedades RB 76-5418 e RB 72-454 tenderam a ter médias superiores as variedades SP 7-1143 e SP 79-1011 em relação a porcentagem de fósforo assimilado.

Tabela 4. Comparações das médias (em \%) para o macronutriente fósforo, entre as variedades testadas. Médias de 6 repetições.

\begin{tabular}{ccc}
\hline Elemento & Variedade & Médias \\
\hline $\mathrm{P}$ & RB 76-5418 & $0,11 \mathrm{a}$ \\
& RB 72-454 & $0,11 \mathrm{a}$ \\
& SP 70-1143 & $0,09 \mathrm{a}$ \\
& SP 79-1011 & $0,09 \mathrm{a}$ \\
\hline
\end{tabular}

$F($ trat $)=2,45$ n.s.

D.M.S. Tukey $(5 \%)=0,02$

C.V. $(\%)=13,55$

Médias seguidas por letras distintas diferem entre si ao nível mínimo de significância de $5 \%$ de probabilidade.

n.s. Não significativo.

\subsubsection{Potássio}

A análise de variância para o macronutriente potássio nas variedades de cana-de-açúcar testadas indicou valor de $\mathrm{F}$ não significativo a $5 \%$ de probabilidade. 
Isto mostrou que não houve diferença significativa em relação à assimilação de potássio entre as variedades testadas (Tabela 5).

Nota-se, através das médias da Tabela 5, que a variedade SP 79-1011 embora não tenha sido estatisticamente diferente das demais, tendeu a ser numericamente superior em relação à porcentagem de potássio assimilado.

Tabela 5. Comparação das médias (em \%) para o macronutriente potássio, entre as variedades testadas. Médias de 6 repetições.

\begin{tabular}{ccc}
\hline Elemento & Variedade & Médias \\
\hline $\mathrm{K}$ & SP 79-1011 & $1,00 \mathrm{a}$ \\
& RB 76-5418 & $0,90 \mathrm{a}$ \\
& RB 72-454 & $0,80 \mathrm{a}$ \\
& SP 70-1143 & $0,78 \mathrm{a}$ \\
\hline
\end{tabular}

F (trat.) $=2,71$ n.s.

D.M.S. Tukey $(5 \%)=0,25$

C.V. $(\%)=17,77$

Médias seguidas por letras distintas diferem entre si ao nível mínimo de significância de $5 \%$ de probabilidade.

n.s. Não significativo.

\subsubsection{Cálcio}

A análise de variância para o macronutriente cálcio nas variedades testadas indicou valor de F significativo ao nível de $1 \%$ de probabilidade.

Nota-se através da Tabela 6 que a variedade RB 72-454, obteve média superior às demais variedades em relação a assimilação de cálcio. 
Observou-se também que as variedades SP 79-1011, RB 76-541'8 e SP

70-1143 não mostraram diferenças significativas nas porcentagens de cálcio assimilado.

Tabela 6. Comparação das médias (em \%) para o macronutriente cálcio, entre as variedades testadas. Médias de 6 repetições.

\begin{tabular}{ccc}
\hline Elemento & Variedade & Médias \\
\hline Ca & RB 72-454 & $0,50 \mathrm{a}$ \\
& SP 79-1011 & $0,39 \mathrm{~b}$ \\
& RB 76-5418 & $0,37 \mathrm{~b}$ \\
& SP 70-1143 & $0,36 \mathrm{~b}$ \\
\hline
\end{tabular}

$\mathrm{F}$ (trat.) $=8,11^{* *}$

D.M.S. Tukey $(5 \%)=0,09$

C.V. $(\%)=13,75$

Médias seguidas por letras distintas diferem entre si ao nível mínimo de significância de $5 \%$ de probabilidade.

** Significativo ao nível de $1 \%$ de probabilidade.

\subsubsection{Magnésio}

A análise de variância para o macronutriente magnésio nas variedades testadas indicou valor de F significativo ao nível de $1 \%$ de probabilidade.

Nota-se, através da Tabela 7 , que a variedade RB $72-454$, obteve média superior às demais variedades em relação a assimilação de magnésio.

Observou-se também que as variedades SP 79-1011, RB 76-5418 e SP 70-1143 não mostraram diferenças significativas na porcentagem de magnésio assimilado. 
Tabela 7. Comparação das médias (em \%) para o macronutriente magnésio, entre as variedades testadas. Médias de 6 repetições.

\begin{tabular}{ccc}
\hline Elemento & Variedade & Médias \\
\hline $\mathrm{Mg}$ & RB 72-454 & $0,12 \mathrm{a}$ \\
& RB 76-5418 & $0,09 \mathrm{~b}$ \\
& SP 70-1143 & $0,09 \mathrm{~b}$ \\
& SP 79-1011 & $0,08 \mathrm{~b}$ \\
\hline
\end{tabular}

$\mathrm{F}$ (trat.) $=8,79 * *$

D.M.S. Tukey $(5 \%)=0,02$

C.V. $(\%)=14,44$

Médias seguidas por letras distintas diferem entre si ao nível mínimo de significância de $5 \%$ de probabilidade.

** Significativo ao nível de $1 \%$ de probabilidade.

\subsubsection{Enxofre}

A análise de variância para o macronutriente enxofre nas variedades testadas indicou valor de $\mathrm{F}$ não significativo a $5 \%$ de probabilidade.

Observou-se que não houve diferença significativa em relação a assimilação de enxofre entre as variedades testadas (Tabela 8).

Nota-se, através das médias da Tabela 8 , que a variedade RB 72-454 embora não tenha sido estatisticamente diferente das demais, tendeu a ser numericamente superior em relação à porcentagem de enxofre assimilado. 
Tabela 8. Comparação das médias (em \%) para o macronutriente enxofre, entre as variedades testadas. Médias de 6 repetições.

\begin{tabular}{ccc}
\hline Elemento & Variedade & Médias \\
\hline $\mathrm{S}$ & $\mathrm{RB} 72-454$ & $0,21 \mathrm{a}$ \\
& SP 70-1143 & $0,20 \mathrm{a}$ \\
& SP 79-1011 & $0,20 \mathrm{a}$ \\
& RB 76-5418 & $0,19 \mathrm{a}$ \\
\hline
\end{tabular}

$\mathrm{F}$ (trat.) $=1,11$ n.s.

D.M.S. Tukey $(5 \%)=0,03$

C.V. $(\%)=12,11$

Médias seguidas por letras distintas diferem entre si ao nivel mínimo de significância de 5\% de probabilidade.

n.s. Não significativo.

\subsubsection{Boro}

A análise de variância para o micronutriente boro nas variedades testadas, indicou valor de $\mathrm{F}$ não significativo a $5 \%$ de probabilidade.

Isto mostrou que não houve diferença significativa em relação à assimilação de boro entre as variedades testadas (Tabela 9).

Nota-se, através das médias da Tabela 9, que a variedade SP 70-1143 embora não tenha sido estatisticamente diferente das demais, tendeu a ser numericamente superior em relação à média de boro assimilado. 
Tabela 9. Comparação das médias (em ppm) para o micronutriente boro, entre as variedades testadas. Médias de 6 repetições.

\begin{tabular}{ccc}
\hline Elemento & Variedade & Médias \\
\hline B & SP 70-1143 & 9,16 a \\
& RB 76-5418 & $8,83 \mathrm{a}$ \\
& SP 79-1011 & $8,33 \mathrm{a}$ \\
& RB 72-454 & $6,50 \mathrm{a}$ \\
\hline
\end{tabular}

$\mathrm{F}($ trat. $)=2,00$ n.s.

D.M.S. Tukey $(5 \%)=3,32$

C.V. $(\%)=25,04$

Médias seguidas por letras distintas diferem entre si ao nível mínimo de significância de $5 \%$ de probabilidade.

n.s. Não significativo.

\subsubsection{Cobre}

A análise de variância para o micronutriente cobre nas variedades testadas indicou valor de F significativo ao nível de $5 \%$ de probabilidade.

Nota-se através da Tabela 10, que a variedade SP 79-1011 obteve média superior às demais variedades, em relação a assimilação de cobre.

Observou-se também que as variedades RB 72-454, RB 76-5418 e SP 70-1143 não mostraram diferenças significativas nas médias de cobre assimilado. 
Tabela 10. Comparação das médias (em ppm) para o micronutriente cobre, entre as variedades testadas. Médias de 6 repetições.

\begin{tabular}{ccc}
\hline Elemento & Variedade & Médias \\
\hline $\mathrm{Cu}$ & SP 79-1011 & $3,17 \mathrm{a}$ \\
& RB 72-454 & $2,83 \mathrm{ab}$ \\
& RB 76-5418 & $2,50 \mathrm{ab}$ \\
& SP 70-1143 & $2,17 \mathrm{~b}$
\end{tabular}

$\mathrm{F}($ trat. $)=3,70^{*}$

D.M.S. Tukey $(5 \%)=0,88$

C.V. (\%) - 20,54

Médias seguidas por letras distintas diferem entre si ao nível mínimo de significância de $5 \%$ de probabilidade.

* Significativo ao nível de $5 \%$ de probabilidade.

\subsubsection{Ferro}

A análise de variância para o micronutriente ferro nas variedades testadas indicou valor de F não significativo a $5 \%$ de probabilidade.

Isto mostrou que não houve diferença significativa em relação à assimilação de ferro entre as variedades testadas (Tabela 11).

Nota-se através das médias da Tabela 11 que a variedade RB 76-5418 embora não tenha sido estatisticamente diferente das demais, tendeu a ser numericamente superior em relação à média de ferro assimilado. 
Tabela 11. Comparação das médias (em ppm) para o micronutriente ferro, entre as variedades testadas. Médias de 6 repetições.

\begin{tabular}{ccc}
\hline Elemento & Variedade & Médias \\
\hline Fe & RB 76-5418 & $370,83 \mathrm{a}$ \\
& SP 79-1011 & $323,33 \mathrm{a}$ \\
& RB 72-454 & $320,66 \mathrm{a}$ \\
& SP 70-1143 & $258,83 \mathrm{a}$ \\
\hline
\end{tabular}

$\mathrm{F}$ (trat.) $=1,83$ n.s.

D.M.S. Tukey $(5 \%)=134,26$

C.V. $(\%)=26,08$

Médias seguidas por letras distintas diferem entre si ao nível mínimo de significância de $5 \%$ de probabilidade.

n.s. Não significativo.

\subsubsection{Manganês}

A análise de variância para o micronutriente manganês, nas variedades testadas, indicou valor de $\mathrm{F}$ significativo ao nível de $1 \%$ de probabilidade.

Nota-se, através da Tabela 12 , que a variedade RB $72-454$ obteve média superior às demais variedades, em relação à assimilação de manganês.

Observou-se também que as variedades SP 70-1143, SP 79-1011 e RB 76-5418 não mostraram diferenças significativas nas médias de manganês assimilado. 
Tabela 12. Comparação das médias (em ppm) para o micronutriente manganês, entre as variedades testadas. Médias de 6 repetições.

\begin{tabular}{ccc}
\hline Elemento & Variedade & Médias \\
\hline Mn & RB 74-454 & $45,67 \mathrm{a}$ \\
& SP 70-1143 & $24,50 \mathrm{~b}$ \\
& SP 79-1011 & $24,17 \mathrm{~b}$ \\
& RB 76-5418 & $23,00 \mathrm{~b}$ \\
\hline
\end{tabular}

$\mathrm{F}($ trat. $)=14,22^{* *}$

D.M.S. Tukey $(5 \%)=11,45$

C.V. $(\%)=24,15$

Médias seguidas por letras distintas diferem entre si ao nível mínimo de significância de $5 \%$ de probabilidade.

** Significativo ao nível de $1 \%$ de probabilidade.

\subsubsection{Zinco}

A análise de variância para o micronutriente zinco nas variedades de cana-de-açúcar testadas indicou valor de F não significativo a 5\% de probabilidade.

Isto mostrou que não houve diferença significativa em relação à assimilação de zinco entre as variedades testadas (Tabela 13).

Nota-se, através das médias da Tabela 13, que a variedade RB 72-454 embora não tenha sido estatisticamente diferente das demais, tendeu a ser numericamente superior em relação a média de zinco assimilado. 
Tabela 13. Comparação das médias (em ppm) para o micronutriente zinco, entre as variedades testadas. Médias de 6 repetições.

\begin{tabular}{ccc}
\hline Elemento & Variedade & Médias \\
\hline $\mathrm{Zn}$ & RB 72-454 & $14,83 \mathrm{a}$ \\
& SP 79-1011 & $13,50 \mathrm{a}$ \\
& RB 76-5418 & $13,50 \mathrm{a}$ \\
& SP 70-1143 & $12,16 \mathrm{a}$ \\
\hline
\end{tabular}

$\mathrm{F}($ trat. $)=2,50$ n.s.

D.M.S. Tukey $(5 \%)=2,72$

C.V. $(\%)=12,47$

Médias seguidas por letras distintas diferem entre si ao nível mínimo de significância de $5 \%$ de probabilidade.

n.s. Não significativo.

\subsection{Características tecnológicas estudadas}

\subsubsection{Pol (\%) cana}

A análise de variância para o teor de sacarose (Pol (\%) cana) indicou valor de $\mathrm{F}$ significativo ao nível de $5 \%$ de probabilidade para a interação entre as variedades, a aplicação de ethephon e os meses de avaliação.

Os dados apresentados na Tabela 14 mostram as médias obtidas para a variedade SP 70-1143 em relação a aplicação ou não de ethephon durante os meses de maio à julho de 1995 . 
Observou-se através da Tabela 14, que houve um aumento no teor de sacarose (Pol (\%) cana) quando a variedade SP 70-1143 foi tratada com ethephon durante o período de avaliação.

Tabela 14. Pol (\%) cana. Comparação das médias mensais da variedade SP $70-1143$, em relação à aplicação ou não de ethephon.

\begin{tabular}{llll}
\hline Variedade & Mês & Tratamento & Pol \% cana \\
\hline SP 70-1143 & Maio & $\begin{array}{l}\text { com ethephon } \\
\text { sem ethephon }\end{array}$ & $11,90 \mathrm{a}$ \\
& & $12,56 \mathrm{a}$ \\
SP 70-1143 & Junho & $\begin{array}{l}\text { com ethephon } \\
\text { sem ethephon }\end{array}$ & $14,43 \mathrm{a}$ \\
& & $13,00 \mathrm{~b}$ \\
SP 70-1143 & Julho & com ethephon & $15,30 \mathrm{a}$ \\
& & sem ethephon & $15,20 \mathrm{a}$ \\
\hline
\end{tabular}

$\mathrm{F}($ trat. $)=3,20^{*}$

C.V. $(\%)=4,50$

Médias seguidas por letras distintas diferem entre si ao nivel mínimo de significância de $5 \%$ de probabilidade.

* Significativo ao nível de $5 \%$ de probabilidade.

Através da Figura 3 observou-se que aos 60 dias após a aplicação do ethephon, realizada em 04/04/95, houve maior diferenciação entre os tratamentos. 


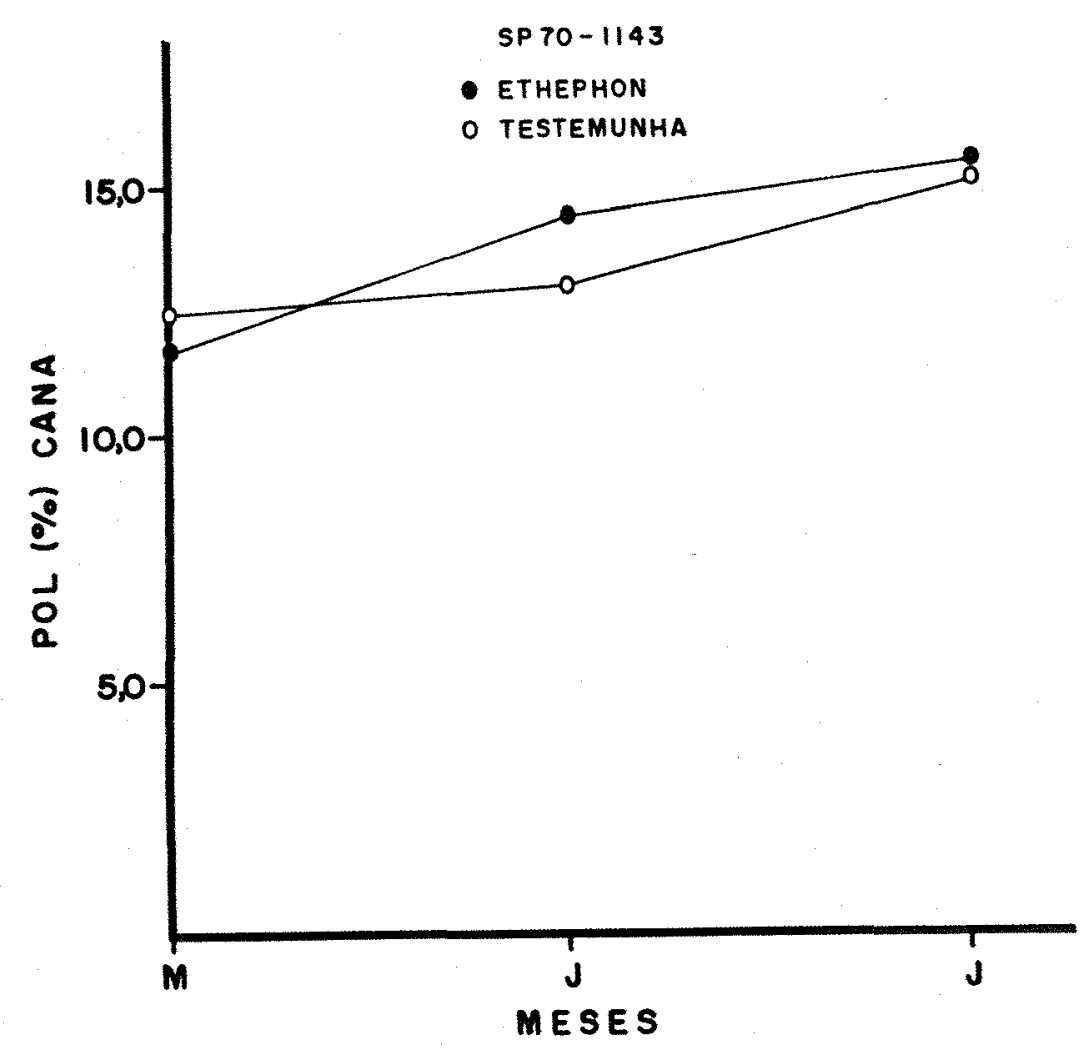

Figura 3. Comportamento da variedade SP 70-1143 para Pol (\%) cana, em relação a aplicação de ethephon, durante os meses de maio à julho de 1995.

Os dados apresentados na Tabela 15 mostram as médias obtidas para a variedade SP 79-1011 em relação a aplicação ou não de ethephon durante os meses de maio a julho de 1995 . 
Nota-se, através da Tabela 15 , que não houve aumento no teor de sacarose (Pol (\%) cana), quanto ao tratamento com ethephon, para a variedade SP 79-1011.

Tabela 15. Pol (\%) cana. Comparação das médias mensais da variedade SP 79-1011, em relação à aplicação ou não de ethephon.

\begin{tabular}{llll}
\hline Variedade & Mês & Tratamento & Pol \% cana \\
\hline SP 79-1011 & Maio & $\begin{array}{l}\text { com ethephon } \\
\text { sem ethephon }\end{array}$ & $12,03 \mathrm{a}$ \\
& & & $12,73 \mathrm{a}$ \\
SP 79-1011 & Junho & $\begin{array}{l}\text { com ethephon } \\
\text { sem ethephon }\end{array}$ & $13,60 \mathrm{a}$ \\
& & & $14,23 \mathrm{a}$ \\
SP 79-1011 & Julho & com ethephon & $15,40 \mathrm{a}$ \\
& & sem ethephon & $15,70 \mathrm{a}$ \\
\hline
\end{tabular}

$\mathrm{F}($ trat $)=3,20^{*}$

C.V. $(\%)=4,50$

Médias seguidas por letras distintas diferem entre si ao nível mínimo de significância de $5 \%$ de probabilidade.

* Significativo ao nível de $5 \%$ de probabilidade.

Através da Figura 4, nota-se que não houve diferença significativa para tratamentos, mas um aumento no teor de sacarose no decorrer dos meses

Os resultados obtidos na Tabela 16 mostram que as médias obtidas para a variedade RB 72-454, em relação à aplicação ou não de ethephon durante os meses de maio a julho de 1995. 


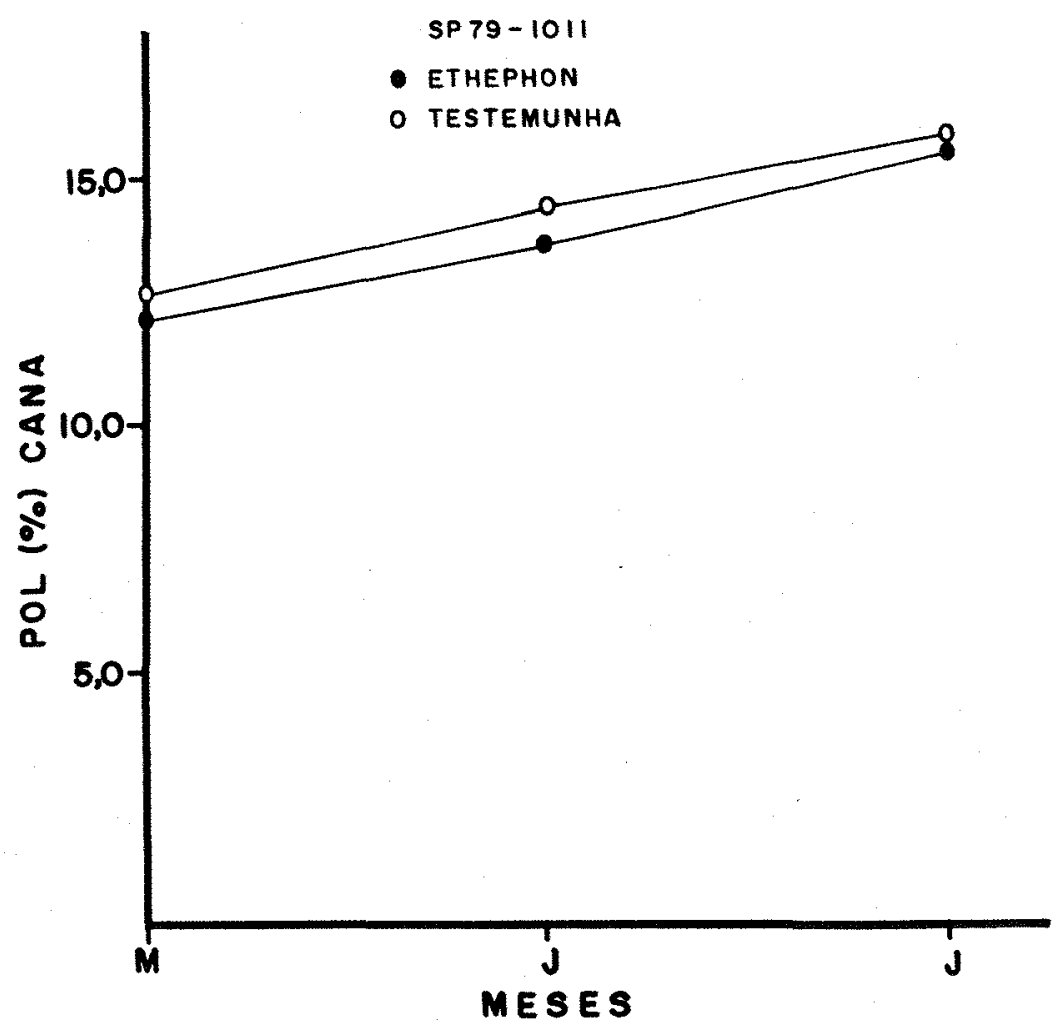

Figura 4. Comportamento da variedade SP 79-1011 para Pol (\%) cana, em relação a aplicação de ethephon, durante os meses de maio à julho de 1995.

Observou-se, através dos resultados, que não houve aumento no teor de sacarose (Pol (\%) cana), quanto ao tratamento com ethephon para a variedade RB 72454. 
Tabela 16. Pol (\%) cana. Comparação das médias mensais da variedade RB 72-454, em relação à aplicação ou não de ethephon.

\begin{tabular}{llll}
\hline Variedade & Mês & Tratamento & Pol \% cana \\
\hline SP 72-454 & Maio & com ethephon & $13,10 \mathrm{a}$ \\
& & sem ethephon & $11,54 \mathrm{~b}$ \\
SP 72-454 & Junho & com ethephon & $13,76 \mathrm{a}$ \\
& & sem ethephon & $14,26 \mathrm{a}$ \\
SP 72-454 & \multirow{2}{*}{ Julho } & com ethephon & $14,70 \mathrm{a}$ \\
& & sem ethephon & $14,53 \mathrm{a}$ \\
\hline
\end{tabular}

$\mathrm{F}$ (trat.) $=3,20^{*}$

C.V. $(\%)=4,50$

Médias seguidas por letras distintas diferem entre si ao nível mínimo de significância de $5 \%$ de probabilidade.

* Significativo ao nivel de $5 \%$ de probabilidade.

Através da Figura 5, nota-se uma diferença significativa no teor de sacarose aos 30 dias após a aplicação do ethephon realizada em 04/04/95.

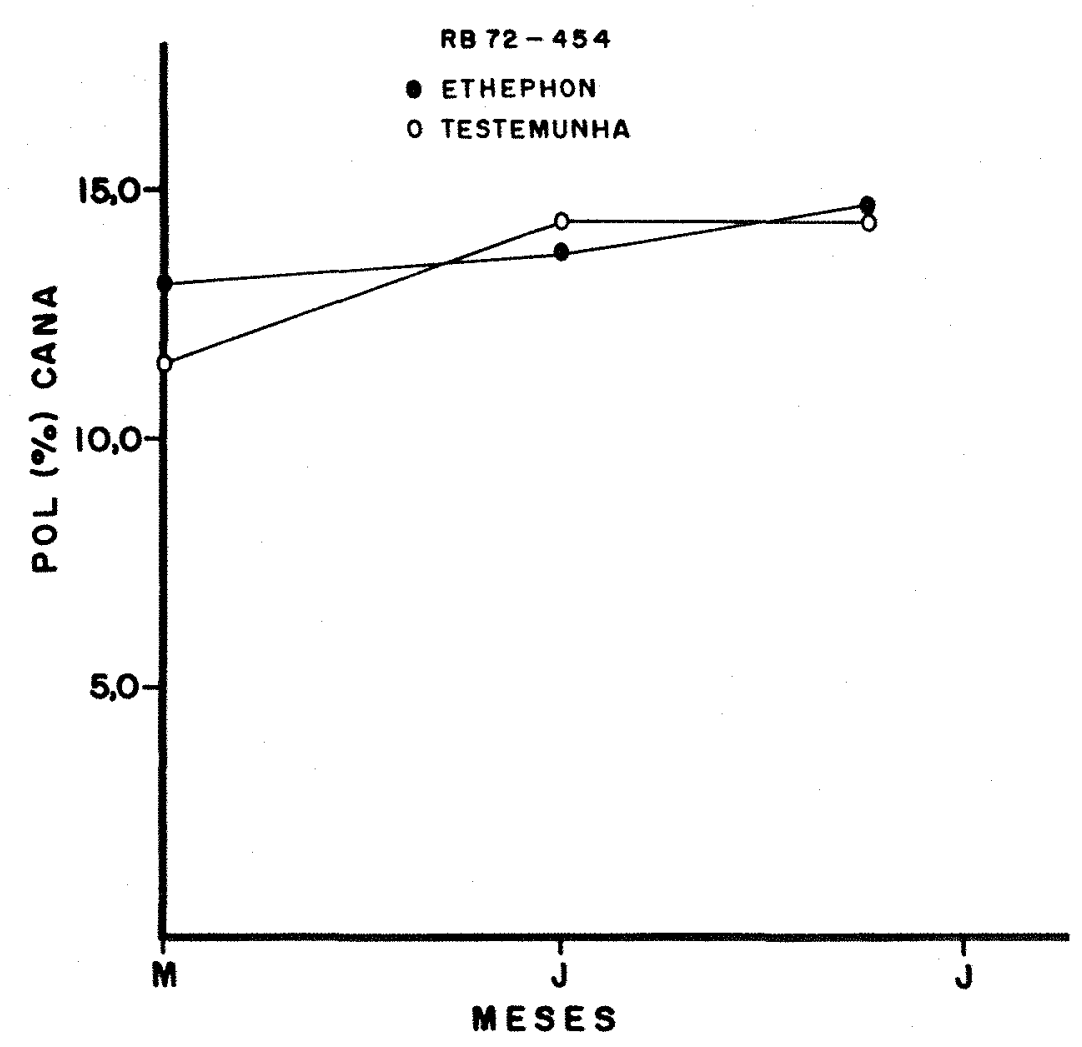

Figura 5. Comportamento da variedade RB 72-454 para Pol (\%) cana, em relação a aplicação de ethephon, durante os meses de maio à julho de 1995 
Os dados apresentados na Tabela 17 mostram as médias obtidas para a variedade $\mathrm{RB}$ 76-5418, em relação à aplicação ou não de ethephon durante os meses de maio à julho de 1995.

Observou-se através dos resultados que não houve aumento no teor de sacarose (Pol (\%) cana), quanto ao tratamento com ethephon, para a variedade RB 765418.

Tabela 17. Pol \% cana. Comparação das médias mensais da variedade SP 76-5418, em relação à aplicação ou não de ethephon.

\begin{tabular}{llll}
\hline Variedade & Mês & Tratamento & Pol \% cana \\
\hline SP 76-5418 & Maio & com ethephon & $12,86 \mathrm{a}$ \\
& & sem ethephon & $12,26 \mathrm{a}$ \\
SP 76-5418 & Junho & com ethephon & $13,43 \mathrm{a}$ \\
& & sem ethephon & $13,73 \mathrm{a}$ \\
SP 76-5418 & Julho & com ethephon & $14,76 \mathrm{a}$ \\
& & sem ethephon & $14,70 \mathrm{a}$ \\
\hline
\end{tabular}

$\mathrm{F}($ trat. $)=3,20^{*}$

C.V. $(\%)=4,50$

Médias seguidas por letras distintas diferem entre si ao nível mínimo de significância de $5 \%$ de probabilidade.

* Significativo ao nível de $5 \%$ de probabilidade.

Através da Figura 6, pode-se comprovar que não houve diferença entre os tratamentos, mas sim um acréscimo da Pol (\%) cana no decorrer dos meses. 


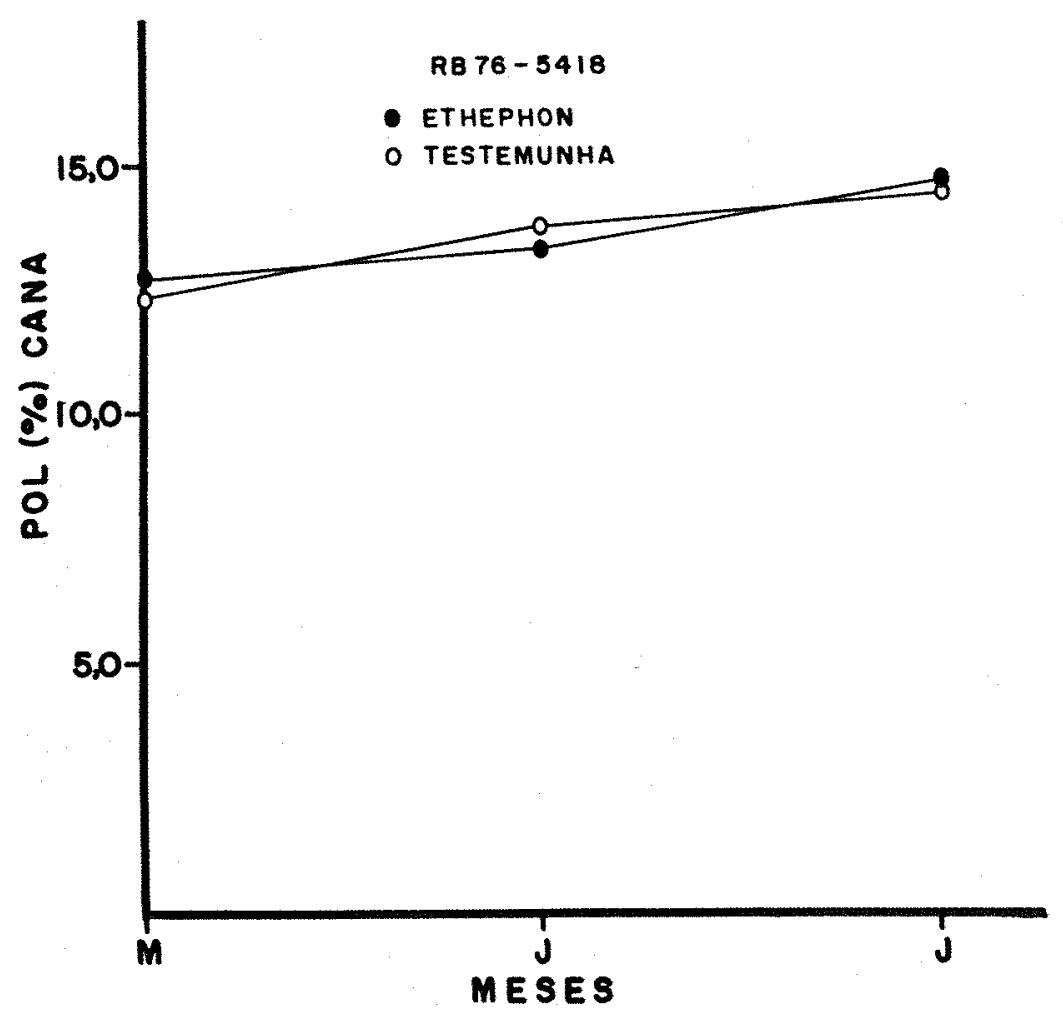

Figura 6. Comportamento da variedade RB 76-5418 para Pol (\%) cana, em relação a aplicação de ethephon, durante os meses de maio à julho de 1995.

\subsubsection{Brix (\%) cana}

A análise de variância para o conteúdo de sólidos solúveis (Brix $(\%)$ cana) indicou valor de $\mathrm{F}$ significativo ao nível de $5 \%$ de probabilidade para a interação entre as variedades de cana-de-açúcar estudadas, e os meses de avaliação (maio a julho de 1995). 
Observou-se também através do quadro de análise de variância que não houve diferença significativa entre as variedades e a aplicação de ethephon ao nível de 5\% de probabilidade.

Nota-se também da Tabela 18 , que só há diferença estatisticamente significativa entre a variedade SP 79-1011 e as variedades RB 72-454 e RB 76-5418 durante o mês de julho de 1995.

A variedade SP 79-1011 obteve média de Brix (\%) cana numericamente superior às demais variedades testadas.

Tabela 18. Brix (\%) cana. Comparação das médias das variedades testadas, dentro de cada mês. Média de 6 repetições.

\begin{tabular}{lcc}
\hline Mês & Variedade & Brix \% cana \\
\hline Maio & RB 72-454 & $15,91 \mathrm{a}$ \\
& RB 76-5418 & $16,06 \mathrm{a}$ \\
& SP 70-1143 & $15,76 \mathrm{a}$ \\
& SP 79-1011 & $15,63 \mathrm{a}$ \\
Junho & & \\
& RB 72054 & $16,30 \mathrm{a}$ \\
& RB 76-5418 & $15,81 \mathrm{a}$ \\
& SP 70-1143 & $16,16 \mathrm{a}$ \\
Julho & SP 79-1011 & $16,33 \mathrm{a}$ \\
& RB 72-454 & $17,33 \mathrm{~b}$ \\
& RB 76-5418 & $17,58 \mathrm{~b}$ \\
& SP 70-1143 & $17,85 \mathrm{ab}$ \\
\hline
\end{tabular}

$\mathrm{F}($ trat. $)=2,65^{*}$

C. V. $(\%)=2,79$

Médias seguidas por letras distintas diferem entre si ao nível de significância de $5 \%$ de probabilidade.

* Significativo ao nível de $5 \%$ de probabilidade. 


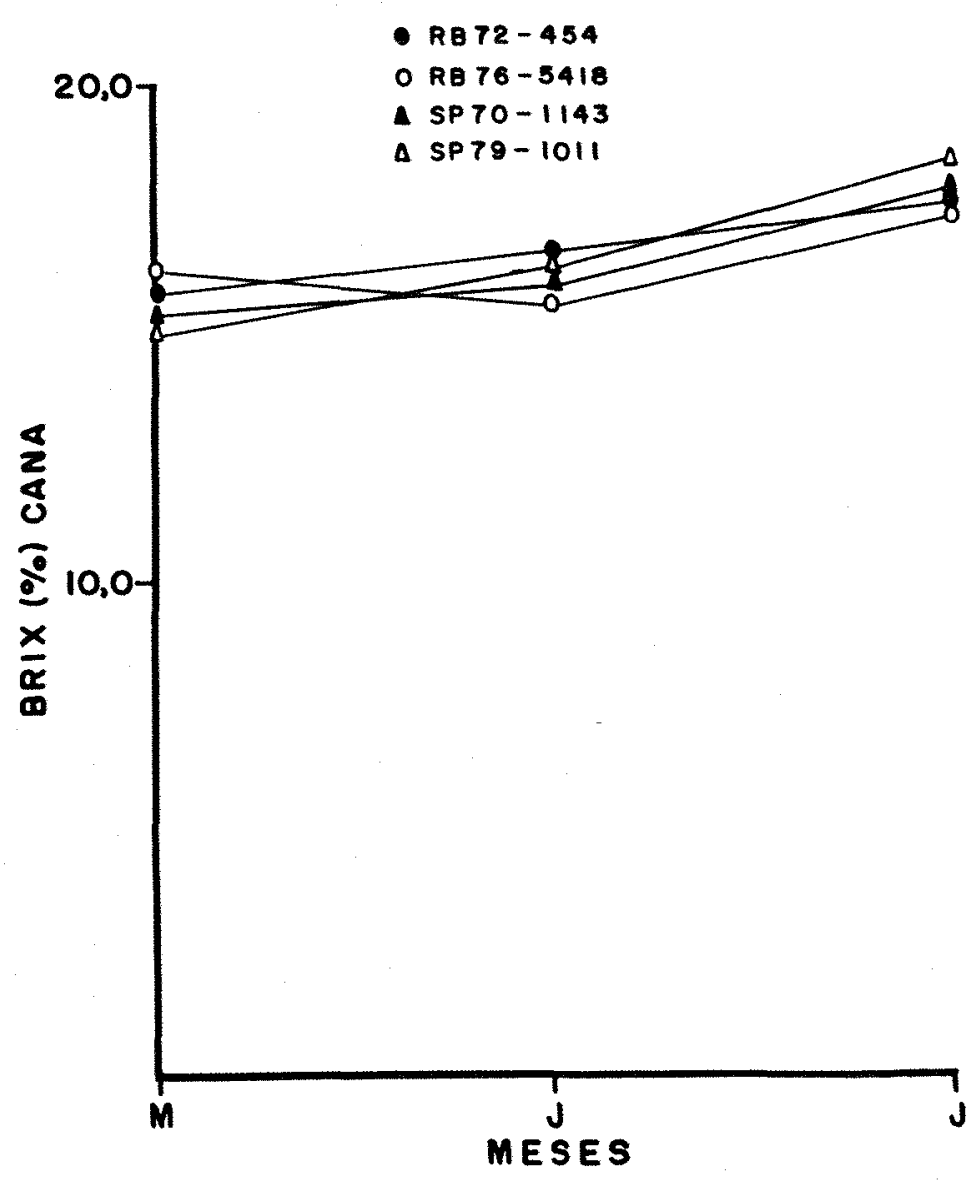

Figura 7. Comportamento das variedades estudadas em relação ao Brix (\%) cana, durante os meses de maio à julho de 1995 .

\subsubsection{Açúcares Redutores (\%) Cana (AR (\%) cana)}

Durante a análise estatistica dos dados obtidos para açúcares redutores (AR (\%) cana) foi observado a presença de um dado discrepante, o qual interferiu negativamente nos resultados do quadro da análise de variância (Apêndice 16). 
Para a confirmação desses indícios, os erros foram manipulados através do módulo INSIGHT do SAS, para experimentos desbalanceados, e a exclusão desse dado discrepante resultou em um rompimento da relação entre os erros e os valores observados da variável, dando uma conformação muito mais adequada as análises.

Afim de verificar a melhora na qualidade dos dados após a exclusão do dado discrepante, foi feita uma nova análise de variância a qual indicou valor de $\mathrm{F}$ significativo ao nivel de $5 \%$ de probabilidade para a interação entre as variáveis ethephon e os meses de avaliação (Apêndice 17).

Os dados apresentados na tabela 19 , mostram as médias obtidas para a variedade SP 70-1143 em relação a aplicação ou não de ethephon durante os meses de maio à julho de 1995 .

Tabela 19. AR (\%) cana. Comparação das médias mensais da variedade SP 70-1143, em relação à aplicação ou não de ethephon.

\begin{tabular}{llll}
\hline Variedade & Mês & Tratamento & AR (\%) cana \\
\hline SP 70-1143 & Maio & com ethephon & $0,55 \mathrm{a}$ \\
& & sem ethephon & $0,71 \mathrm{a}$ \\
SP 70-1143 & Junho & com ethephon & $0,15 \mathrm{~b}$ \\
& & sem ethephon & $0,34 \mathrm{a}$ \\
& & & \\
SP 70-1143 & Julho & com ethephon & $0,16 \mathrm{a}$ \\
& & sem ethephon & $0,17 \mathrm{a}$ \\
\hline
\end{tabular}

$\mathrm{F}$ (trat. $)=2,93^{*}$

C.V. $(\%)=14,60$

Médias seguidas por letras distintas diferem entre si ao nível mínimo de significância de $5 \%$ de probabilidade.

* Significativo ao nivel de $5 \%$ de probabilidade. 
Observou-se através dos resultados que nos meses de maio e junho, as testemunhas possuíam níveis de açúcares redutores superiores aos tratados com ethephon.

Nota-se também que, no mês de julho os níveis de AR (\%) cana foram praticamente iguais nos tratamentos dentro da variedade SP 70-1143.

Através da Figura 8, nota-se que houve decréscimo nos níveis de açúcares redutores nos dois tratamentos durante os meses de maio e junho de 1995. Durante o mês de julho, os níveis de açúcares redutores das testemunhas continuaram caindo, enquanto que para as plantas tratadas com ethephon os níveis de AR (\%) cana mantiveramse constantes.

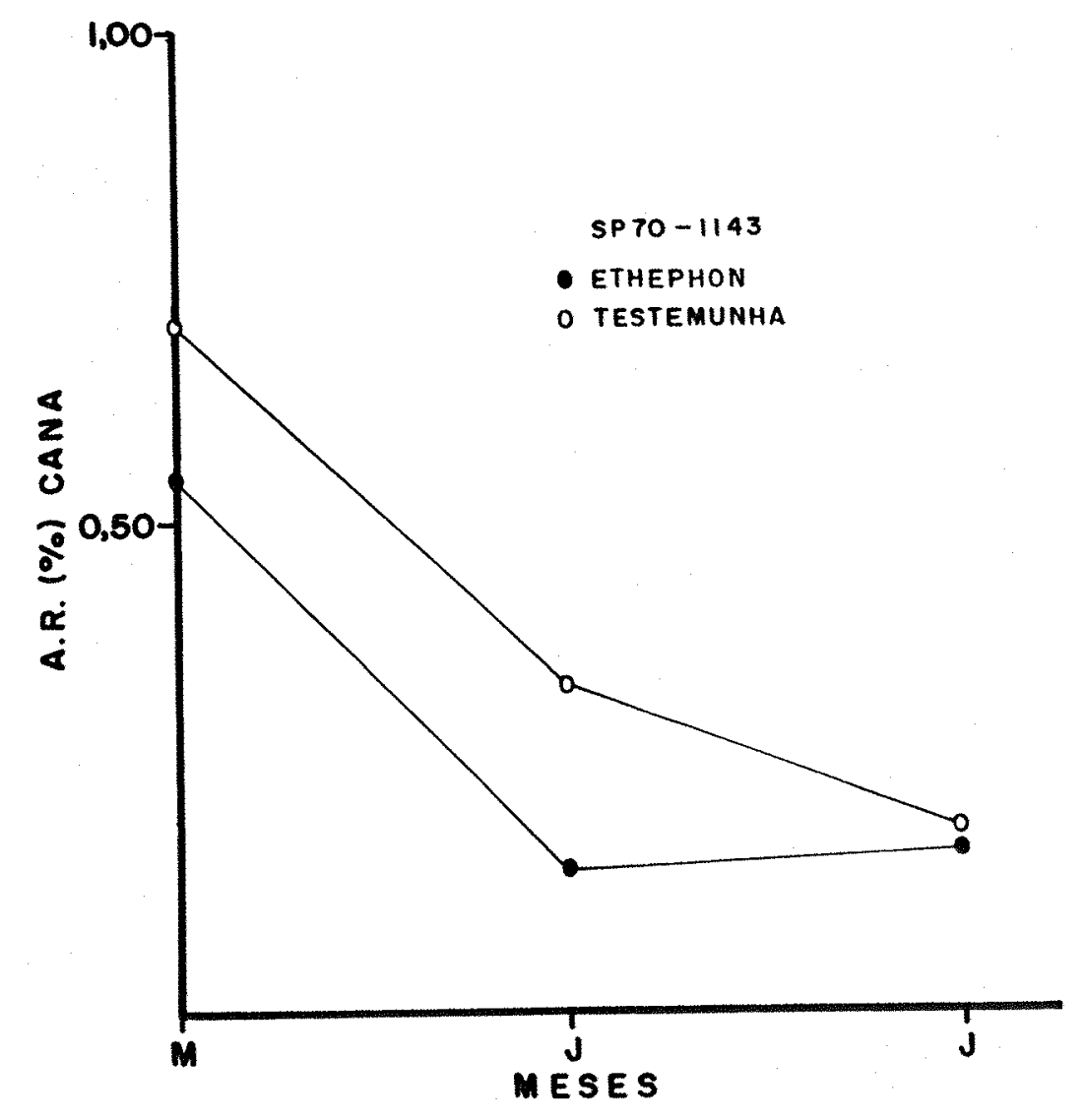

Figura 8. Comportamento da variedade SP 70-1143 para AR (\%) cana, em relação a aplicação e ethephon, durante os meses de maio à julho de 1995. 
Os dados apresentados na Tabela 20 , mostram as médias obtidas para a variedade SP 79-1011 em relação a aplicação ou não de ethephon durante os meses de maio a julho de 1995 .

Observou-se através dos resultados que não houve diferença significativa entre os tratamentos durante o período de avaliação.

Tabela 20. AR (\%) cana. Comparação das médias mensais da variedade SP 79-1011, em relação à aplicação ou não de ethephon.

\begin{tabular}{llll}
\hline Variedade & Mês & Tratamento & AR $(\%)$ cana \\
\hline SP 79-1011 & Maio & $\begin{array}{l}\text { com ethephon } \\
\text { sem ethephon }\end{array}$ & $0,60 \mathrm{a}$ \\
& & $0,56 \mathrm{a}$ \\
SP 79-1011 & Junho & com ethephon & $0,30 \mathrm{~b}$ \\
& sem ethephon & $0,30 \mathrm{a}$ \\
SP 79-1011 & Julho & com ethephon & $0,16 \mathrm{a}$ \\
& & sem ethephon & $0,21 \mathrm{a}$ \\
\hline
\end{tabular}

$\mathrm{F}($ trat. $)=2,93^{*}$

C.V. $(\%)=14,60$

Médias seguidas por letras distintas diferem entre si ao nivel mínimo de significância de $5 \%$ de probabilidade.

* Significativo ao nível de $5 \%$ de probabilidade.

Através da Figura 9, nota-se que houve decréscimo nos niveis de AR $(\%)$ cana durante o período de avaliação. 


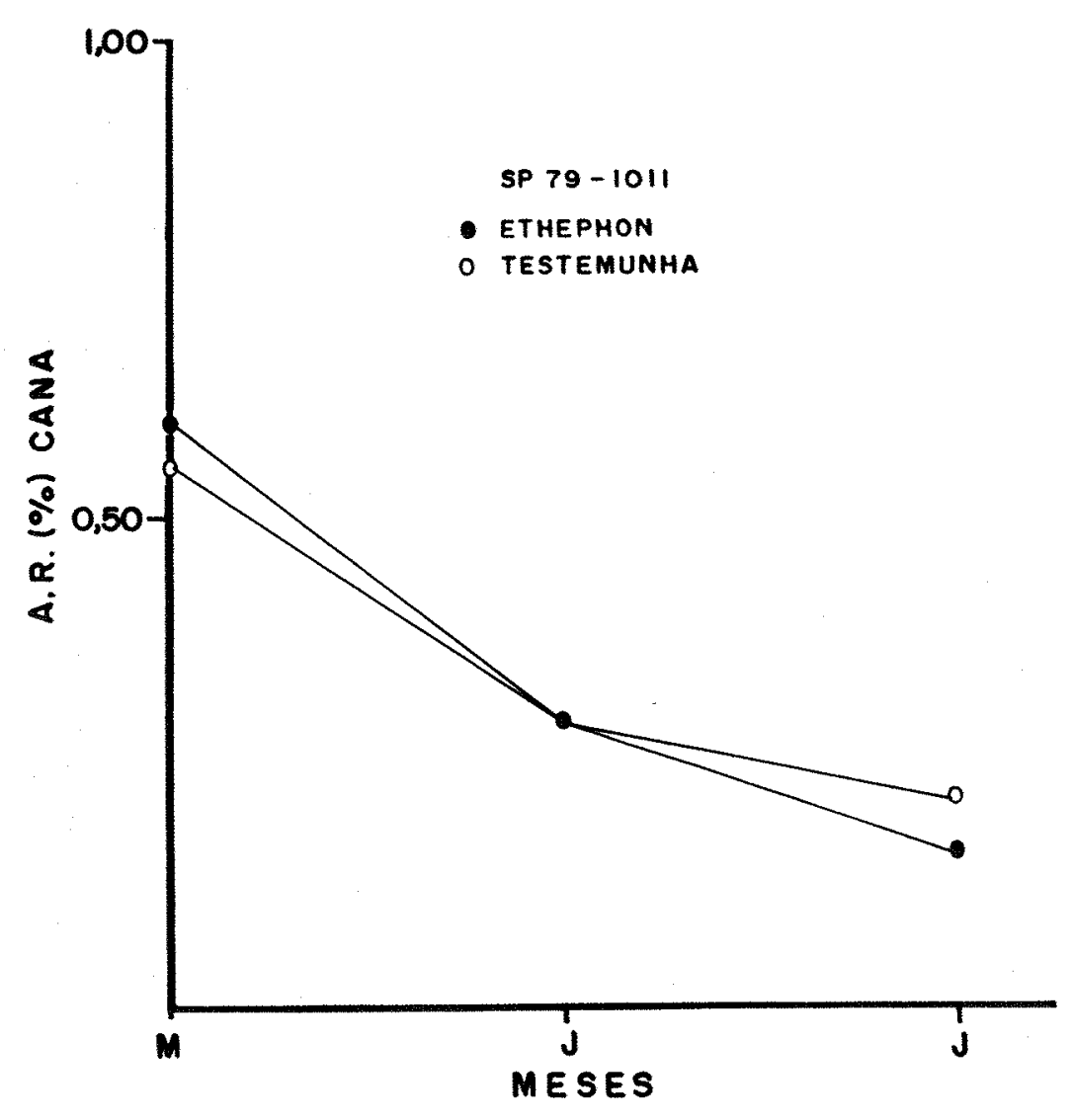

Figura 9. Comportamento da variedade SP 79-1011 para AR (\%) cana, em relação a aplicação de ethephon, durante os meses de maio à julho de 1995.

Os dados apresentados pela Tabela 21 , mostram as médias obtidas para a variedade RB 72-454 em relação a aplicação ou não de ethephon durante os meses de maio à julho de 1995 .

Observou-se através dos resultados que não houve diferença significativa entre os tratamentos durante o período de avaliação. 
Tabela 21. AR (\%) cana. Comparação das médias mensais da variedade SP 72-454, em relação à aplicação ou não de ethephon.

\begin{tabular}{llll}
\hline Variedade & Mês & Tratamento & AR (\%) cana \\
\hline SP 72-454 & Maio & $\begin{array}{l}\text { com ethephon } \\
\text { sem ethephon }\end{array}$ & $0,51 \mathrm{a}$ \\
& & $0,57 \mathrm{a}$ \\
SP 72-454 & Junho & com ethephon & $0,19 \mathrm{a}$ \\
& sem ethephon & $0,25 \mathrm{a}$ \\
SP 72-454 & Julho & com ethephon & $0,19 \mathrm{a}$ \\
& & sem ethephon & $0,19 \mathrm{a}$
\end{tabular}

$\mathrm{F}($ trat. $)=2,93 *$

C.V. $(\%)=14,60$

Médias seguidas por letras distintas diferem entre si ao nível mínimo de significância de $5 \%$ de probabilidade.

* Significativo ao nível de $5 \%$ de probabilidade.

Através da Figura 10, nota-se que houve decréscimo nos níveis de açúcares redutores nos dois tratamentos durante os meses de maio e junho de 1995.

Durante o mês de julho, os níveis de açúcares redutores das testemunhas continuaram caindo, enquanto que para as plantas tratadas com ethephon os níveis de AR (\%) cana mantiveram-se constantes. 


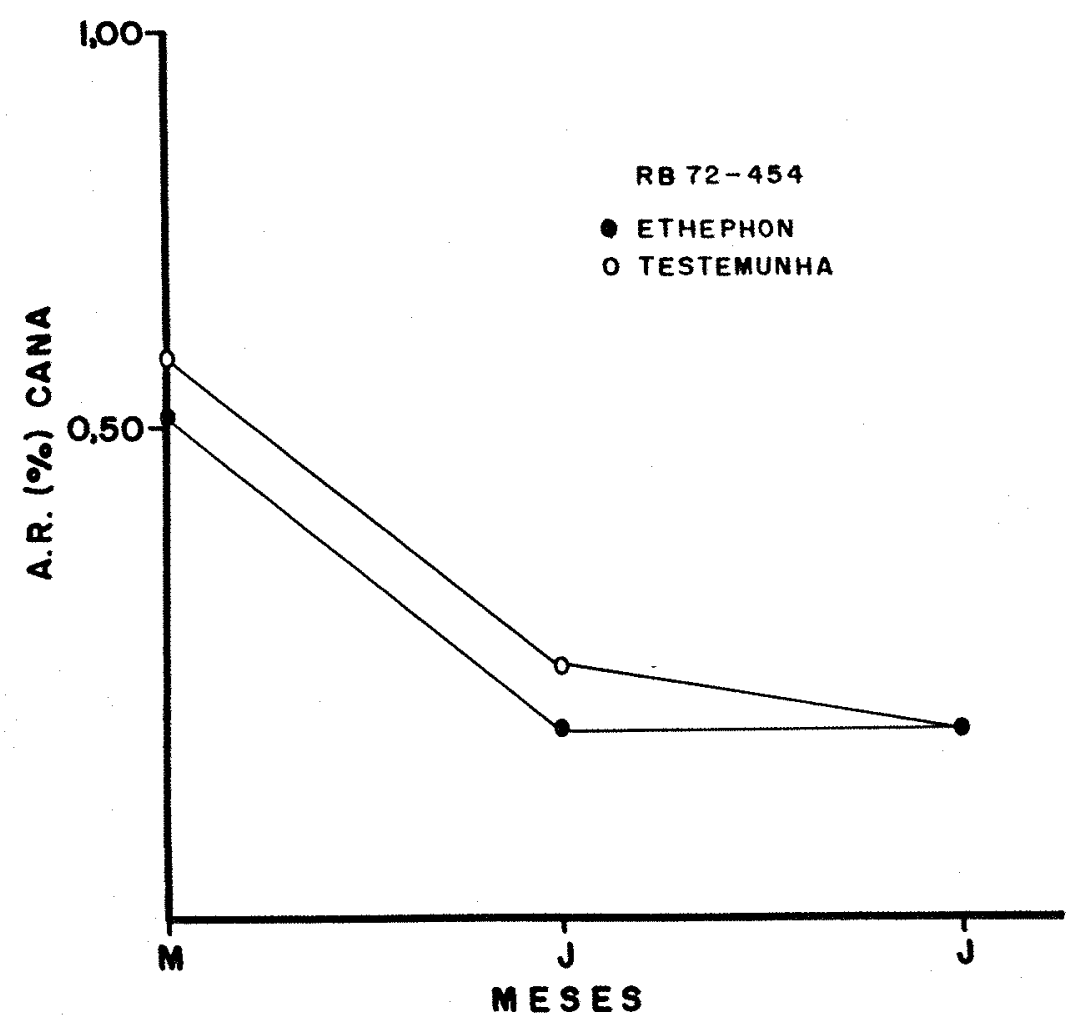

Figura 10. Comportamento da variedade RB 72-454 para AR (\%) cana, em relação a aplicação de ethephon, durante os meses de maio à julho de 1995.

Os dados apresentados na Tabela 22 , mostram as médias obtidas para a variedade RB 76-5418 em relação a aplicação ou não de ethephon durante os meses de maio à julho de 1995 .

Observou-se, através dos resultados, que somente no mês de maio houve diferença significativa entre os tratamentos. As testemunhas obtiveram indices de açúcar redutores mais elevados do que as plantas tratadas com ethephon. 
Tabela 22. AR (\%) cana. Comparação das médias mensais da variedade SP $76-5418$, em relação à aplicação ou não de ethephon.

\begin{tabular}{llll}
\hline Variedade & Mês & Tratamento & AR (\%) cana \\
\hline SP 76-5418 & Maio & com ethephon & $0,43 \mathrm{a}$ \\
& sem ethephon & $0,62 \mathrm{a}$ \\
SP 76-5418 & Junho & com ethephon & $0,21 \mathrm{~b}$ \\
& & sem ethephon & $0,27 \mathrm{a}$ \\
SP 76-5418 & Julho & com ethephon & $0,22 \mathrm{a}$ \\
& & sem ethephon & $0,23 \mathrm{a}$ \\
\hline
\end{tabular}

$\mathrm{F}($ trat. $)=2,93^{*}$

C.V. $(\%)=14,60$

Médias seguidas por letras distintas diferem entre si ao nível mínimo de significância de 5\% de probabilidade.

* Significativo ao nível de $5 \%$ de probabilidade.

Através da Figura 11, nota-se que houve decréscimo nos níveis de açúcares redutores nos dois tratamentos durante os meses de maio e junho de 1995. Durante o mês de julho, os níveis de açúcares redutores das testemunhas continuaram caindo, enquanto que para as plantas tratadas com ethephon, os niveis de A.R. \% cana mantiveramse constantes. 


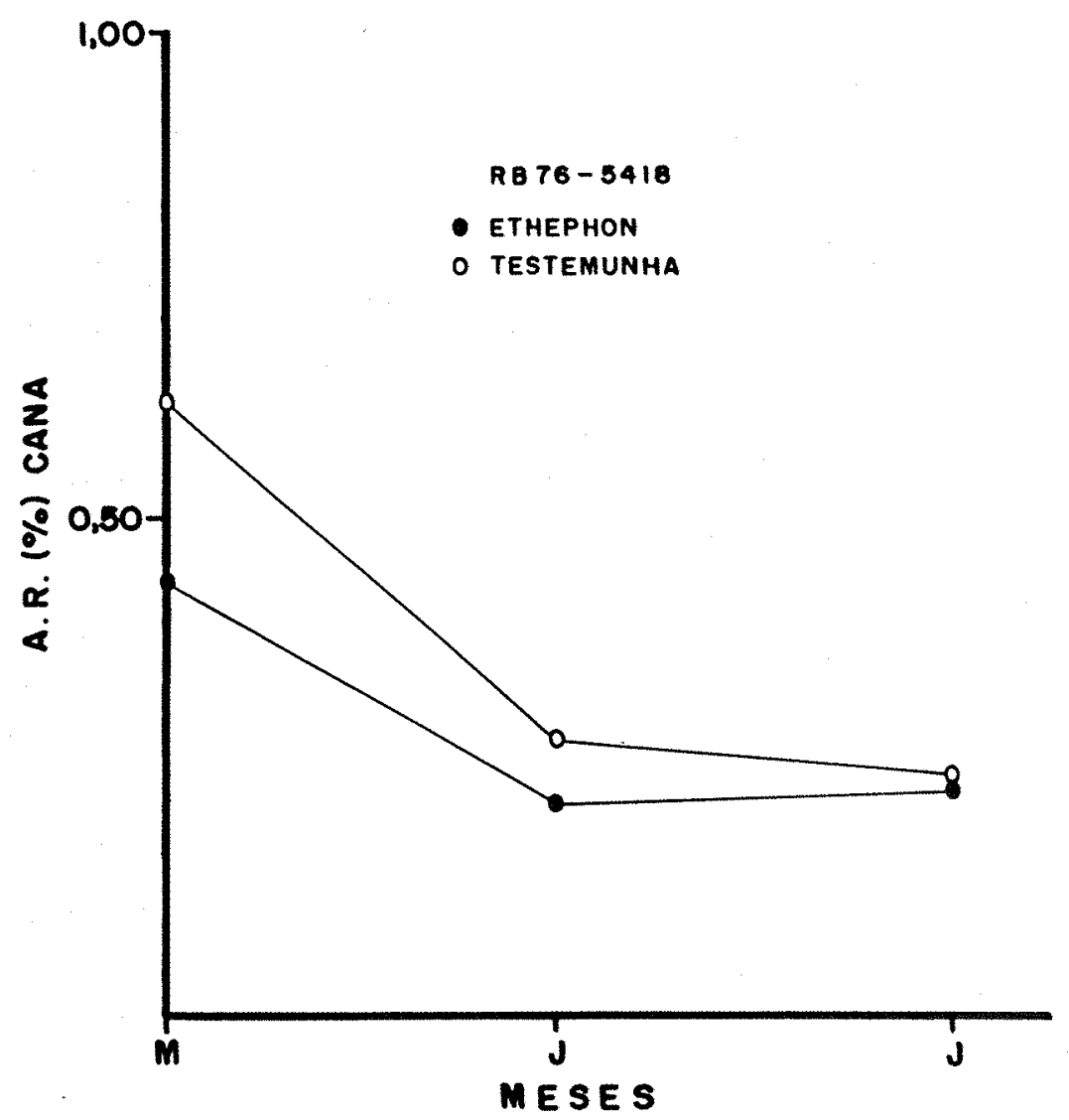

Figura 11. Comportamento da variedade RB 76-5418 para AR (\%) cana, em relação a aplicação de ethephon, durante os meses de maio à julho de 1995.

\subsubsection{Fibra (\%) Cana}

Durante a análise estatística dos dados obtidos para Fibra (\%) cana, foi observado a presença de um dado discrepante, a qual interferiu negativamente nos resultados do quadro da análise de variância (Apêndice 18).

Para a confirmação desses indícios, os erros foram manipulados através do módulo INSIGHT do SAS, para experimentos desbalanceados, e a exclusão desse dado discrepante resultou em um rompimento da relação entre os erros e os valores observados da variável, dando uma conformação muito mais adequada as análises. 
Afim de verificar a melhora na qualidade dos dados após a exclusão do dado discrepante foi feita uma nova análise de variância a qual indicou valor de $F$ significativo ao nivel de $5 \%$ de probabilidade para as interações entre as variedades e os meses e também entre o efeito do ethephon durante o período de avaliação (Apêndice 19).

Os dados apresentados na Tabela 23, mostram que a variedade SP 79-1011 apresentou um comportamento diferente das demais variedades durante o período de avaliação. Observou-se também uma quantidade de fibra estatisticamente superior no mês de junho em todas as variedades de cana-de-açúcar testadas.

Tabela 23. Fibra (\%) cana. Comparação das médias dos meses (maio, junho e julho de 1995) em relação a cada uma das variedades de cana-de-açúcar testadas. Média de 6 repetições.

\begin{tabular}{lcc}
\hline Variedade & Mês & Fibra (\%) cana \\
\hline RB 72-454 & maio & $11,50 \mathrm{~b}$ \\
& junho & $12,80 \mathrm{a}$ \\
& julho & $10,80 \mathrm{~b}$ \\
& maio & $12,01 \mathrm{~b}$ \\
RB 76-5418 & junho & $14,45 \mathrm{a}$ \\
& julho & $11,41 \mathrm{~b}$ \\
& maio & $10,25 \mathrm{~b}$ \\
SP 70-1143 & junho & $13,00 \mathrm{a}$ \\
& julho & $10,26 \mathrm{~b}$ \\
& maio & $11,30 \mathrm{c}$ \\
SP 79-1011 & junho & $12,18 \mathrm{a}$ \\
& julho & $10,41 \mathrm{~b}$ \\
\hline
\end{tabular}

$\mathrm{F}($ trat. $)=2,45^{*}$

C.V. $(\%)=6,16$

Médias seguidas por letras distintas diferem entre si ao nível mínimo de significância de 5\% de probabilidade.

* Significativo ao nivel de $1 \%$ de probabilidade. 


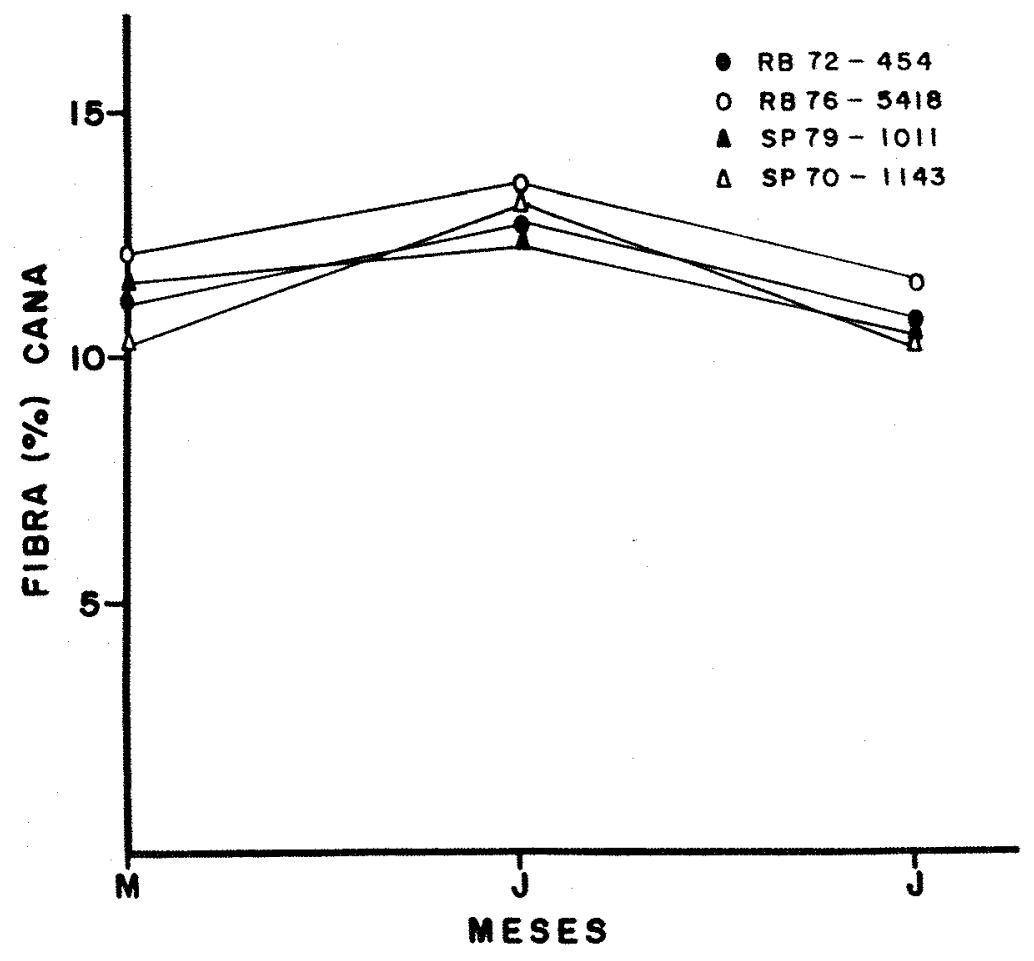

Figura 12. Comportamento das variedades de cana-de-açúcar estudadas em relação a Fibra (\%) cana durante os meses de maio à julho de 1995 .

Considerando-se resultados apresentados na Tabela 24 , verificou-se que as diferenças entre os meses em relação a Fibra (\%) cana, são maiores quando não se aplicou o ethephon. 
Tabela 24. Fibra (\%) cana. Comparação das médias dos meses (maio, junho e julho de 1995) em relação a aplicação ou não de ethephon.

\begin{tabular}{lcc}
\hline Tratamento & Mês & Fibra (\%) cana \\
\hline com ethephon & maio & $10,93 \mathrm{~b}$ \\
& junho & $12,02 \mathrm{a}$ \\
& julho & $10,39 \mathrm{~b}$ \\
sem ethephon & maio & \\
& junho & $11,60 \mathrm{~b}$ \\
& julho & $14,20 \mathrm{a}$ \\
\hline
\end{tabular}

$\mathrm{F}$ (trat.) $=8,29^{* *}$

C.V. $(\%)=6,16$

Médias seguidas por letras distintas diferem entre si ao nível mínimo de significância de $5 \%$ de probabilidade.

* Significativo ao nível de $1 \%$ de probabilidade.

\subsubsection{Pureza (\%) Cana}

A análise de variância para Pureza $(\%)$ cana, indicou valor de F significativo ao nível de $1 \%$ de probabilidade somente para a variável mês, sendo que para a aplicação de ethephon não houve diferença entre as variedades..

Os dados apresentados na Tabela 25 mostram que durante os meses de maio, junho e julho de 1995 houve um aumento na Pureza (\%) cana nas variedades de canade-açúcar estudadas. 
Tabela 25. Pureza (\%) cana nos meses de maio, junho e julho de 1995. Médias de 6 repetições.

\begin{tabular}{lc}
\hline Mês & Pureza \% cana \\
\hline Maio & $78,86 \mathrm{~b}$ \\
Junho & $84,75 \mathrm{a}$ \\
Julho & $85,50 \mathrm{a}$ \\
\hline F (trat.) $=74,45^{* *}$ & \\
C. V. $(\%)=2,40$ & \\
\hline
\end{tabular}

Médias seguidas por letras distintas diferem entre si ao nível mínimo de significância de $5 \%$ de probabilidade.

** Significativo ao nível de $1 \%$ de probabilidade. 


\section{DISCUSSÃO}

\subsection{Altura das plantas}

Os resultados verificados para altura das plantas (Tabela 1), mostraram melhor desempenho para a variedade $\mathrm{RB}$ 76-5418 em relação as demais durante o período de avaliação.

Observou-se também através da Figura 1, que as variedades $\mathrm{RB} 76-5418$ e RB 72-454 apresentaram maior crescimento quando comparadas com as variedades SP 79-1011 e SP 70-1143.

Pode-se justificar o melhor desempenho das variedades RB 76-5418 e RB 72-454 pelas suas qualidades genéticas e pelo fato de terem apresentado um menor perfilhamento (Figura 2), o que contribuiu para o desenvolvimento em altura.

Nota-se também que a variedade SP $70-1143$ foi a que apresentou a menor altura (Tabela 1) e o maior perfilhamento durante as contagens (Tabela 2). 
Considerando-se as características mencionadas, verifica-se concordância entre os resultados obtidos e a descrição dessas características feita por GHELLER et al. (1990) para as variedades RB 72-454 e RB 76-5418.

\subsection{Número de perfilhos}

Para essa característica observaram-se diferenças significativas entre os meses e as variedades testadas (Tabela 2).

O fato de haver interação, entre as variedades de cana-de-açúcar e os meses de avaliação, pode ser justificada pelas características de cada uma delas associadas às modificações ambientais, tais como: umidade, temperatura e luminosidade (ROCHA, 1984).

Observou-se que durante os meses de maio à setembro de 1994, houve um período de baixa precipitação pluviométrica, o que pode ter dificultado o processo de perfilhamento das variedades estudadas. Tais fatores ambientais, interagem entre si e com a planta, ocasionando um perfilhamento mais lento. Esses resultados estão de acordo com os citados por ROCHA (1984).

Com relação as variedades estudadas, observou-se superioridade de perfilhamento da variedade SP 70-1143 em relação as demais. 


\subsection{Nutrição mineral}

Nas análises das amostras foliares obtidas, verificaram-se que não ocorreram diferenças significativas na assimilação dos macronutrientes $\mathrm{N}, \mathrm{P}, \mathrm{K}, \mathrm{S}$ e para os micronutrientes $\mathrm{B}$, Fe e $\mathrm{Zn}$ nas quatro variedades de cana-de-açúcar testadas.

Observou-se uma maior porcentagem de nitrogênio em relação aos outros macronutrientes, visto que a necessidade deste nutriente pela cana-de-açúcar é crucial no período de formação da cultura.

HUMBERT (1974), observou que as plantas de cana-de-açúcar têm a necessidade de armazenar nitrogênio para posterior utilização, principalmente no processo de perfilhamento. ORTEGA (1962) demonstrou que os melhores rendimentos são obtidos quando a adubação nitrogenada é realizada dentro dos primeiros quatro meses de idade da cultura.

Segundo DAS (1936), o nitrogênio aumenta o comprimento dos colmos da cana-de-açúcar, porém esse aumento faz com que a parede celular fique mais delgada, podendo ocorrer, em casos extremos, paredes finas, principalmente na parte central do colmo, que apresentam tendência de rompimento, indicando que o nutriente reduz a porcentagem de fibras na planta.

Observou-se que a variedade RB $72-454$ foi a que teve melhor assimilação para os nutrientes cálcio, magnésio e manganês (Tabelas 6, 7 e 12). 
Segundo HUMBERT \& MARTIN (1955), o cálcio é essencial para a formação de pectatos de cálcio, os quais participam do desenvolvimento da parede celular e lamela média, que liga as células entre si.

De acordo com CLEMENTS (1959), o cálcio tem a propriedade de favorecer a absorção de magnésio, o que está de acordo com a análise nutricional feita para a variedade $\mathrm{RB} 72-454$.

Observou-se também que a variedade SP 79-1011 obteve a maior assimilação do micronutriente cobre em relação as demais variedades estudadas (Tabela 10).

\subsection{Aplicação de ethephon}

A maturação é considerada como um dos aspectos mais importantes na produção da cana-de-açúcar. A falta de cultivares produtivos, com maturação precoce, pode ser contornada com a utilização de maturadores químicos para o suprimento da usina durante o ano todo com cana madura.

Em condições de alta temperatura durante todo ano, em que a cana-deaçúcar vegeta continuamente, também se pode provocar a maturação através da aplicação de maturadores.

Mais recentemente, o ethephon, ácido (2-cloroetil) fosfồnico, tem se revelado um eficiente maturador da cana-de-açúcar (CASTRO, 1983). 
Os resultados obtidos no presente trabalho, mostraram que a utilização de ethephon na cultura da cana-de-açúcar pode ser interessante para diversas variedades.

\subsection{Pol (\%) cana}

Através dos resultados obtidos para as variedades SP 70-1143, SP 79-1011, RB 72-454 e RB 76-5418, conclui-se que a utilização do ethephon na fase de maturação possibilitou um maior incremento no teor de sacarose, tendo destaque para a variedade RB 72-454, a qual obteve melhores índices para pol (\%) cana aos 30 dias após a aplicação de ethephon e para a variedade SP 70-1143 com melhores indices para pol ( $\%$ ) cana aos 60 dias após o tratamento realizado no dia 04/04/95. Após esse período não houve diferença em relação ao teor de sacarose entre as variedades, devido à maturação natural ter sido favorável.

MUTTON (1993), trabalhando com as variedades SP 70-1143, RB 72-454, SP 71-6163 e RB 76-5418, observou significativo aumento no teor de sacarose durante os ciclos das variedades SP 70-1143 e RB 72-454, sendo que os melhores resultados foram obtidos aos 60 dias após a aplicação, estando de acordo com os resultados mencionados no presente trabalho.

Utilizando as variedades SP 70-1143, RB 78-5148 e RB 72-454, JANEGITZ (1991), observou um acréscimo considerável, também, nos teores de sacarose para a variedade SP 70-1143, confirmando os resultados já mencionados. 


\subsection{Brix (\%) cana}

Os resultados obtidos para o conteúdo de sólidos solúveis (Brix $(\%)$ cana) nas variedades SP 70-1143, SP 79-1011, RB 72-454 e RB 76-5418, mostraram não haver diferenças significativas entre elas em relação aos efeitos provocados pelo ethephon durante a fase de maturação.

Foi verificado apenas um pequeno aumento na porcentagem de sólidos solúveis no decorrer dos meses avaliados, sendo que, a variedade SP 79-1011 foi a que obteve a maior média durante o período de avaliação.

CAMPOS (1992), trabalhando com as variedades RB 72-454, SP 791011 e SP 70-1143, verificou que aos 45 dias após a aplicação de ethephon, houve um ligeiro aumento na porcentagem de Brix (\%) cana nas variedades observadas.

\subsection{Açúcares Redutores (\%) cana (A.R. \% cana)}

Os resultados observados, quanto a porcentagem de açúcares redutores (glicose e frutose) entre as variedades estudadas, mostraram uma diminuição mais acentuada para esta característica tecnológica nos tratamentos onde foi utilizado o ethephon.

Esta diminuição ocorreu devido a transformação dos açúcares redutores em sacarose, durante o processo fotossintético das plantas. 
ACCORSI (1963), verificou que o conteúdo de sacarose na cana-deaçúcar vai aumentando de menos de $10 \%$ do peso seco da cana jovem para $45 \%$ ou mais na cana madura. Inversamente, a água na planta cai de $83 \%$ para $71 \%$ durante o ciclo da cultura.

A relação inversa entre sacarose e água é tão íntima que, em culturas irrigadas, suspende-se o fornecimento de água para acelerar o amadurecimento. Este tratamento provoca um aumento na relação sacarose/fibra, devido provavelmente a conversão de açúcares redutores em sacarose.

CAMPOS (1992), utilizando as variedades SP 70-1143, SP 79-1011 e RB 72-454 verificou uma diminuição mais acentuada dos açúcares redutores quando estas eram tratadas com ethephon.

\subsection{Fibra (\%) cana}

As análises efetuadas no presente trabalho mostraram uma maior porcentagem de fibra nas variedades estudadas aos 60 dias após a aplicação de ethephon, sendo que aos 90 dias as variedades tinham uma diminuição na sua porcentagem de fibra.

Tais resultados se justificam provavelmente devido as menores precipitações pluviométricas ocorridas durante o mês de junho de 1995 (Apêndice 21). 
CAMPOS (1992), verificou que nas variedades SP 70-1143, SP 79-1011 e RB 72-454, houve um decréscimo em fibra (\%) cana quando estas eram tratadas com ethephon.

\subsection{Pureza (\%) cana}

Os resultados obtidos para pureza (\%) cana, só foram válidos em relação aos meses, sendo que não houve relação entre a pureza (\%) cana e a aplicação de ethephon, para as variedades estudadas.

Foi observado que durante os meses de maio, junho e julho de 1995 , houve uma sensível melhora na pureza $(\%)$ cana em todas as variedades.

CAMPOS (1992), estudando as variedades RB 72-454, SP 70-1143 e SP 79-1011, verificou que houve um aumento da pureza (\%) cana quando estas eram tratadas com ethephon.

Trabalhando com as variedades SP 70-1143 e SP 70-6163, VOSS (1992), também verificou um aumento da pureza (\%) cana para a variedade SP $70-1143$ quando esta era tratada com ethephon durante o ciclo da cultura. 


\section{CONCLUSÕES}

Dos estudos feitos para a caracterização das 4 variedades de cana-deaçúcar analisadas, ou seja, SP 70-1143, SP 79-1011, RB 72-454 e RB 76-5418, destacam-se as seguintes conclusões:

1 - Existe diferença significativa com relação a altura das plantas nas variedades estudadas, sendo que, a variedade RB $76-5418$ obteve o melhor desenvolvimento em altura durante o período de análise.

2 - Quanto ao perfilhamento, pode-se concluir que a variedade SP 70-1143 apresentou melhor potencial de brotação em relação as demais variedades. 
3 - Pode-se concluir através da análise nutricional foliar das variedades estudadas, que existe uma maior exigência do macronutriente nitrogênio, no desenvolvimento inicial das culturas. Também ficou comprovado que a variedade RB 72 454, obteve melhor assimilação dos nutrientes cálcio, magnésio e manganês.

4 - Observou-se que a variedade SP 70-1143 foi a que melhor respondeu a aplicação de ethephon em relação as demais variedades, diante das características tecnológicas estudadas.

5 - Observou-se que as variedades necessitam de diferentes intervalos de tempo para a resposta ao ethephon. 


\section{REFERÊNCIAS BIBLIOGRÁFICAS}

ACCORSI, W.R. Apontamento sobre sistemática, morfologia e anatomia e fisiologia da cana-de-açúcar. Piracicaba, ESALQ/USP, 1963. 30p.

ALEXANDER, A.G. In vitro effects of silicon on the action patterns on sugarcane acid invertase. The Journal Agriculture of Unviersity of Puerto Rico, Rio Piedras, 311 $22,1968$.

ALFONSI, R.R.; PEDRO Jr, M.J.; BRUNINI, O; BARBIERI, V. Condições climáticas para a cana-de-açúcar. In: PARANHOS, S.B. et al. Cana-de-açúcar. Cultivo e utilização. Campinas, Fundação Cargill, 1987. p.42-55.

ALMEIDA, M. Caracterização organográfica e bioquímica de dez cultivares de cana-deaçúcar (Saccharum spp.). Piracicaba, ESALQ/USP, 1986. (Dissertação de Mestrado).

ALVAREZ, F.C. Cana de azúcar. Venezuela, Fondo Nacional de Investigaciones Agropecuárias, 1975. 669p. 
ALVAREZ, F.C. El registro agronômico de elements y su aplicación en Venezuela Caracas, Ministério de Agricultura y Cria, 1959. 125p.

BACCHI, O.O.S. \& SOUZA, J.A.G.C. Minimum threshold temperature for sugar cane growth. In: CONGRESS ISSCT, São Paulo, 1978. p.1173-41.

BARBIERI, V. Medidas e estimativas do consumo hídrico em cana-de-açúcar (Saccharum spp.). Piracicaba, ESALQ/USP, 1981. 82p. (Dissertação de Mestrado).

BARBIERI, V.; BACCHIO, O.O.S; VILLA NOVA, N.A. Análise do fator temperatura média do ar no desenvolvimento da cana-de-açúcar. In: CONGRESSO BRASILEIRO DE AGROMETEOROLOGIA, $1^{\circ}$,, Mossoró, 1979. 35p.

BARNES, A.C. The sugar cane. New York, Interscience, 1964. 456p.

BASILE, F.A. Desenvolvimento, produção e qualidade tecnológica de três variedades de cana-de-açúcar, conduzidas sob espaçamento reduzido e tradicional de plantio em condições de cana-de-ano. Piracicaba, 1992. 114p. (Dissertação de Mestrado)

BRINHOLI, O. Resistência ao frio de diferentes variedades de cana-de-açúcar (Saccharum spp.). Piracicaba, ESALQ/USP, 1975. 48p. (Dissertação de Mestrado)

BULL, T.A. \& GLASZIOU, K.T. Sugar cane. In: EVANS, L.T. Crop physiology. Cambridge University, 1975. p.51-72.

CAMARGO, P.N. Fisiologia da cana-de-açúcar. Piracicaba, ESALQ/USP, 1968. 38p. (mimeografado). 
CAMPOS, N.S. A utilização de Ethrel em escala comercial na Açucareira Corona S/A Usina Bonfim. Anais II Encontro Cana-de-açúcar, Rhodia Agro S.A., São Paulo, 1992. p.93-104.

CASAGRANDE, A.A. Tópicos de morfologia e fisiologia de cana-de-açúcar. Jaboticabal: FUNEP, 1991. 157p.

CASTRO, P.R.C. Reguladores vegetais: perspectivas de aplicação em cana-de-açúcar Revista da STAB, 1(3): 26-28, 1983.

CHAPMAN, H.D. \& PRATT, P.F. Métodos de análises para suelos, plantas y ágeros Trad. Agustin Contin, México, Editorial Trillas, 1973. 195p.

CHEONG, Y.W.Y.; HEITS, A; DEVILE, J. Foliar symptoms silicon deficiency in the sugar cane plant. In: CONGRESS ISSCT, 14\% ., New Orleans, 1971. Proceedings, 1972. p. $766-76$.

CHRISTOFFOLETI, P.J. Aspectos fisiológicos da brotação, perfilhamento e florescimento da cana-de-açúcar. Piracicaba, ESALQ/USP, 1986. 80p. (mimeografado).

CLEMENTS, H.F. Sugarcane nutrition and culture. Lucknow, Indian Institute of Sugarcane. Research, 1959. 188p.

CLEMENTS, H.F.; MARTIN, J.P.; MORIGUCHI, S. Composition of sugar cane plants grown in deficiency nutrient solution. Hawaiian Planters Record, Honolulu, 45: 227 $39,1941$.

COPERSUCAR - Boletim Técnico. Edição especial, maio 1991. p.10-11. 
DAS, U.K. Nitrogen nutrition of sugar cane. Plant Physiology, Bethesda, 11: 251-317, 1936.

DILLEWIJN, C. van. Botany of sugarcane. Waltham, Chronica Botanica, 1952. 371p.

DILLEWIJN, C.N. Botanique de La Canne a Sucre. Wageningen, Veenman \& Zonen. Holand, 1960. 59lp.

EPSTEIN, E. Nutrição mineral de plantas; princípios e perspectivas. Rio de Janeiro, Livros Técnicos e Científicos, 1975. 375p.

FERNANDES, A.J. Manual da cana-de-açúcar. Piracicaba, Livroceres, 1984.

GHELLER, A.C.; ROLIM, J.C.; LIMA FILHO, S.A. Variedades de cana-de-açúcar, contribuição das novas variedades "RB”. Álcool e Açúcar, São Paulo, 10(52): 16-22, jan/fev. 1990.

GRACIANO, P.A. \& RAMALHO, F.J.G.P. Efeito da mato competição na cultura da canade-açúcar (Saccharum spp.). In: CONGRESSO BRASILEIRO DE HERBICIDAS E ERVAS DANINHAS, $14^{\circ}$, Campinas, 1982. Resumos. p. 29.

HARTT, C.E. Studies on the invertase of sugarcane. Hawaiian Planter's Record, Honolulu, 37: 13-4, 1933.

HARTT, C.E. \& BURR, G.O. Factors affecting photosynthesis in sugarcane. In: CONGRESS OF THE INTERNATIONAL SOCIETY OF SUGARCANE TECHNOLOGIST'S, 12, San Juan, 1965. Proceedings. Amsterdam, Elsevier, 1967. p.590-609. 
HAUCK, F.W. \& DICKINSON, J. Conveniência y experimentación con potasio en el cultivo de caña de azucar. Atac: Revista Técnica Informativa, La Habana, 13: 626, 1954.

HUMBERT, R.P. El cultivo de la caña de azúcar. México, Continental, 1974. 719p.

HUMBERT, R.P. Sugarcane production: growing interest in chemical ripeners world. Farming, 16(12): 25-26, 1974.

HUMBERT, R.P. \& MARTIN, V.P. Nutritional deficiency symptoms in sugarcane. The Hawaiian Planter's Record, Honolulu, 95: 102, 1955.

INNES, R.F. El abonamiento de la caña de azúcar. Span, London, 2(3): 52-4, 1959.

JANEGITZ, I. \& GARNS, M.F. Avaliação dos efeitos de Ethrel em diferentes variedades de cana-de-açúcar. Anais Encontro Cana-de-açúcar, Rhodia Agro S.A., São Paulo, 1994. p.31-33.

JORDAN, H.V. \& ENSMINGER, L.E. The role of sulfur in soil fertility. Advances in Agronomy, New Jersey, 1: 407-34, 1958.

LORENZI, H.J. Interferência da tiririca com a cana-de-açúcar. In: CONGRESSO BRASILEIRO DE HERBICIDAS E ERVAS DANINHAS, 15\%., Belo Horizonte, 1984. Resumos. p. 11.

LOTT, W.L.; NERY, J.P.; GALLO, J.R.; MEDCALF, J.C. A técnica de análise foliar aplicada ao cafeeiro. Boletim do Instituto Agronômico, Campinas, n'.79: p.40, 1956. 
MACHADO, E.C.; PEREIRA, A.R.; FAHAL, J.I.; ARRUDA, H.V.; CIONE, J. Índices biométricos de duas variedades de cana-de-açúcar. Pesq. Agropec. Bras., 17(9): 1982. p. 1323-1329.

MALAVOLTA, E. Análise química dos teores totais. In: Curso Internacional de Diagnose Foliar. I.I.C.A. - ESALQ, Piracicaba, 1: 1-36, 19

MALAVOLTA, E. Manual de química agrícola - nutrição de plantas e fertilidade do solo. São Paulo, Ceres, 1976. 528p.

MALAVOLTA, E.; VITTI, G.C.; OLIVEIRA, S.A. de. Avaliação do estado nutricional das plantas. Princípios e aplicações. Piracicaba, Assoc. Bras para Pesq. da Potassa e do Fosfato, 1989. 201p.

MUTTON, M.A. Avaliação de Ethrel sobre a biomassa e incremento de sacarose na cultura da cana-de-açúcar. Anais III Encontro Ethrel: cana-de-açúcar, Rhodia Agro S.A., São Paulo, 1993. p.13-22.

ORTEGA, D. Época de aplicación del nitrogeno en la caña de azúcar. Agronomia Tropical, 13(3): 139-48, 1962.

PLANALSUCAR. Cultura da cana-de-açúcar. Manual de Orientação. Piracicaba, IAA, Coord. Reg. Sul, 1986. 56p. (mimeografado).

RESENDE, L.C.L.; MILLER, L.C.; MEDEIROS, A.M.L.; ROSSETO, A.J. Alternativas para a introdução de novas variedades de cana-de-açúcar na Usina São João. Açúcar, Álcool e Subprodutos, Piracicaba, 6(3): 12-9, jan/fev. 1988.

ROCHA, A.M.C. Emergência, perfilhamento e produção de colmos da cana-de-açúcar (Saccharum spp.) em função das épocas de plantio no Estado de São Paulo. Piracicaba, 1984. 154p. (Dissertação de Mestrado). 
ROLIM, J.C. \& CHRISTOFFOLETI, P.J. Período crítico de competição de plantas daninhas com a cana-de-açúcar (Saccharum spp.), 5(22): 21-6, 1982.

ROSTRON, H.; DURANT, H.K.; LANG, C.A. Chemical ripening with Ethrel unders commercial condition in Swaziland. Proc. South African Sug. Technol. Assoc, $n^{\circ} .50$ : p. 87-89, 1976.

SARRUGE, J.R. \& HAAG, H.P. Análises químicas em plantas. Departamento de Química - ESALQ/USP, Piracicaba., 1974. 56p. (publicação didática).

SCHECK, H. Influence of potassium on carbohydrate metabolism and on the carbohydrates of cultivated plants. Separata Inst. Agr. Chem., Univ. Munchenuleikenstephan, Germany, 1953. 12p.

SINGH, V.S. Nitrogen and sugarcane. IV. Leaf nitrogen in response to single and piecemeal application of fertilizer and its relations with growth. Indian Sugar, New Delhi, 24: 541-48, 1974.

SOBRAL, A.F. \& WEBER, S. Nutrição mineral da cana-de-açúcar (micronutrientes). In: ORLANDO FILHO et al. Nutrição e adubação da cana-de-açúcar no Brasil. Piracicaba, IAA, Planalsucar, 1983. p.103-22.

THOMPSON, J.F. Sulfur metabolism in plants. Ann. Rev. Plant Physiology, Palo Alto, 18: $59-84,1967$.

VOSS, L.N. A influência da utilização de Ethrel na redução do custo de transporte na Equipav S/A - Açúcar e Álcool. Anais II Encontro Cana-de-açúcar, Rhodia Agro S.A., São Paulo, 1993. p.69-77.

YANG, P.C. \& PAO, T.P. Artificial ripening of sugar cane with chemicals. Taiwan Sugar, 21(3): 74-80, 1974 
APÊNDICE 
Apêndice 1. Análise de variância para altura das plantas $(\mathrm{cm})$, realizadas no período de 28/03/94 à 28/10/94.

\begin{tabular}{lrrrrr}
\hline Causas da Variação & G.L. & S.Q. & Q.M. & Valor F & Prov. $>$ F \\
\hline Variedade & 3 & 119867,7541240 & 39955,9180413 & $449,6175^{* *}$ & 0,00001 \\
Meses & 7 & 274665,8487311 & 39237,9783902 & $441,5386^{* *}$ & 0,00001 \\
Variedades x Meses & 21 & 10343,0678079 & 492,5270385 & $5,5423^{* *}$ & 0,00001 \\
Resíduo & 288 & 25593,5416669 & 88,8664641 & & \\
& & & & & \\
Total & 319 & 430470,2123300 & & & \\
\hline
\end{tabular}

Média geral $=102,713440$

Coeficiente de variação $=9,18 \%$

Apêndice 2. Análise de variância para contagem do número de perfilhos, realizadas no período de 28/03/94 à 28/10/94.

\begin{tabular}{lrrrrr}
\hline Causas da Variação & G.L. & \multicolumn{1}{c}{ S.Q. } & Q.M. & Valor F & Prov. $>$ F \\
\hline Variedade & 3 & 3750,2250000 & 1250,0750000 & $223,3362^{* *}$ & 0,00001 \\
Meses & 7 & 1516,5000000 & 216,6428571 & $38,7102^{* *}$ & 0,00001 \\
Variedades x Meses & 21 & 272,2250000 & 12,9630952 & $2,3163^{* *}$ & 0,00139 \\
Residuo & 288 & 1611,8000000 & 5,5965278 & & \\
& & & & & \\
Total & 319 & 7150,7500000 & & & \\
\hline
\end{tabular}

Média geral $=10,87500$

Coeficiente de variação $=22,13 \%$ 
Apêndice 3. Análise de variância para o macronutriente nitrogênio, dentro das variedades de cana-de-açúcar testadas.

\begin{tabular}{lccccc}
\hline Causas da Variação & G.L. & S.Q. & Q.M. & Valor F & Prob. > F \\
\hline Variedades & 3 & 0,1195465 & 0,03998488 & 2,9788 & 0,05521 \\
Resíduo & 20 & 0,2675493 & 0,0133775 & & \\
& & & & & \\
Total & 23 & 0,3870958 & & & \\
\hline
\end{tabular}

Média geral $=1,17083$

Coeficiente de Variação $=10,54 \%$

Apêndice 4. Análise de variância para o macronutriente fósforo, dentro das variedades de cana-de-açúcar testadas.

\begin{tabular}{lccccc}
\hline Causas da Variação & G.L. & S.Q. & Q.M. & Valor F & Prob. > F \\
\hline Variedades & 3 & 0,0015125 & 0,0005042 & 2,4693 & 0,09071 \\
Resíduo & 20 & 0,0040384 & 0,0002042 & & \\
& & & & & \\
Total & 23 & 0,0055958 & & & \\
\hline
\end{tabular}

Média geral $=0,10517$

Coeficiente de Variação $=13,55 \%$ 
Apêndice 5. Análise de variância para o macronutriente potássio, dentro das variedades de cana-de-açúcar testadas.

\begin{tabular}{lccccc}
\hline Causas da Variação & G.L. & S.Q. & Q.M. & Valor F & Prob. > F \\
\hline Variedades & 3 & 0,1962340 & 0,0654113 & 2,7159 & 0,07117 \\
Resíduo & 20 & 0,4816994 & 0,0240850 & & \\
& & & & & \\
Total & 23 & 0,6779334 & & & \\
\hline
\end{tabular}

Média geral $=0,873333$

Coeficiente de Variação $=17,77 \%$

Apêndice 6. Análise de variância para o macronutriente cálcio, dentro das variedades de cana-de-açúcar testadas.

\begin{tabular}{lccccc}
\hline Causas da Variação & G.L. & S.Q. & Q.M. & Valor F & Prob. $>$ F \\
\hline Variedades & 3 & 0,0756459 & 0,0252153 & 8,1143 & 0,00127 \\
Residuo & 20 & 0,0621500 & 0,0031075 & & \\
& & & & & \\
Total & 23 & 0,1377958 & & & \\
\hline
\end{tabular}

Média geral $=0,405417$

Coeficiente de Variação $=13,75 \%$ 
Apêndice 7. Análise de variância para o macronutriente magnésio, dentro das variedades de cana-de-açúcar testadas.

\begin{tabular}{lccccc}
\hline Causas da Variação & G.L. & S.Q. & Q.M. & Valor F & Prob. > F \\
\hline Variedades & 3 & 0,0048833 & 0,0016278 & 8,7988 & 0,00089 \\
Resíduo & 20 & 0,0037000 & 0,0001850 & & \\
Total & 23 & 0,0085833 & & & \\
\hline
\end{tabular}

Média geral $=0,09417$

Coeficiente de Variação $=14,44 \%$

Apêndice 8. Análise de variância para o macronutriente enxofre, dentro das variedades de cana-de-açúcar testadas.

\begin{tabular}{lccccc}
\hline Causas da Variação & G.L. & S.Q. & Q.M. & Valor F & Prob. > F \\
\hline Variedades & 3 & 0,0019500 & 0,0006500 & 1,1175 & 0,36612 \\
Residuo & 20 & 0,0116333 & 0,0005817 & & \\
& & & & & \\
Total & 23 & 0,0135833 & & & \\
\hline
\end{tabular}

Média geral $=0,199167$

Coeficiente de Variação $=12,11 \%$ 
Apêndice 9. Análise de variância para o micronutriente boro, dentro das variedades de canade-açúcar testadas.

\begin{tabular}{lccccc}
\hline Causas da Variação & G.L. & S.Q. & Q.M. & Valor F & Prob. > F \\
\hline Variedades & 3 & 25,4583333 & $\mathbf{8 , 4 8 6 1 1 1 1}$ & 2,0085 & 0,14430 \\
Resíduo & 20 & 84,5000000 & 4,2250000 & & \\
& & & & & \\
Total & 23 & 109.9583333 & & & \\
\hline
\end{tabular}

Média geral $=8,208333$

Coeficiente de Variação $=25,04 \%$

Apêndice 10. Análise de variância para o micronutriente cobre, dentro das variedades de cana-de-açúcar testadas.

\begin{tabular}{lccccc}
\hline Causas da Variação & G.L. & S.Q. & Q.M. & Valor F & Prob. $>$ F \\
\hline Variedades & 3 & 3,3333333 & 1,1111111 & 3,7037 & 0,02824 \\
Resíduo & 20 & 6,0000000 & 0,3000000 & & \\
& & & & & \\
Total & 23 & 9,3333333 & & & \\
\hline
\end{tabular}

Média geral $=2,666667$

Coeficiente de Variação $=20,54 \%$ 
Apêndice 11. Análise de variância para o micronutriente ferro, dentro das variedades de cana-de-açúcar testadas.

\begin{tabular}{lccccc}
\hline Causas da Variação & G.L. & S.Q. & Q.M. & Valor F & Prob. > F \\
\hline Variedades & 3 & 37961,5000000 & 12653,8333333 & 1,8345 & 0,17252 \\
Resíduo & 20 & 137952,3333333 & 6897,6166667 & & \\
Total & 23 & 175913,8333333 & & & \\
\hline
\end{tabular}

Média geral $=318,416660$

Coeficiente de Variação $=26,08 \%$

Apêndice 12. Análise de variância para o micronutriente manganês, dentro das variedades de cana-de-açúcar testadas.

\begin{tabular}{lccccc}
\hline Causas da Variação & G.L. & S.Q. & Q.M. & Valor F & Prob. > F \\
\hline Variedades & 3 & 2141,6666667 & 713,8888889 & 14,2256 & 0,00011 \\
Resíduo & 20 & 1003,6666667 & 50,1833333 & & \\
& & & & & \\
Total & 23 & 3145,3333333 & & & \\
\hline
\end{tabular}

Média geral $=29,333334$

Coeficiente de Variação $=24,15 \%$ 
Apêndice 13. Análise de variância para o micronutriente ferro, dentro das variedades de cana-de-açúcar testadas.

\begin{tabular}{lccccc}
\hline Causas da Variação & G.L. & S.Q. & Q.M. & Valor F & Prob. $>$ F \\
\hline Variedades & 3 & 21,3333333 & 7,1111111 & 2,5098 & 0,08714 \\
Resíduo & 20 & 56,6666667 & 2,8333333 & & \\
Total & 23 & 78,000000 & & & \\
\hline
\end{tabular}

Média geral $=13,500000$

Coeficiente de Variação $=12,47 \%$

Apêndice 14. Análise de variância para Pol \% cana, dentro das variedades de cana-de-açúcar testadas.

\begin{tabular}{lccccc}
\hline Causa da Variação & G.L. & Tipo III SQ & $\begin{array}{c}\text { Quadrado } \\
\text { Médio }\end{array}$ & $\begin{array}{c}\text { Valor } \\
\text { F }\end{array}$ & \\
& & & & Pr F \\
Cana & 3 & 1,16708333 & 0,38902778 & 0,45 & 0,7218 \\
Resíduo (A) & 8 & 6,85777778 & 0,85722222 & & \\
Ethrel & 1 & 0,08680556 & 0,08680556 & 0,43 & 0,5299 \\
Cana x Ethrel & 3 & 2,45041667 & 0,81680556 & 4,06 & 0,0503 \\
Resíduo (B) & 8 & 1,61111111 & 0,20138889 & & \\
Mês & 2 & 85,23361111 & 42,61680556 & 111,56 & 0,0001 \\
Cana x Mês & 6 & 3,34416667 & 0,55736111 & 1,46 & 0,2236 \\
Ethrel x Mês & 2 & 0,15361111 & 0,07680556 & 0,29 & 0,8189 \\
Cana x Ethrel x Mês & 6 & 7,32416667 & 1,22069444 & $3,20 *$ & 0,0143 \\
Resíduo (C) & 32 & 12,2244444 & 0,3820139 & & \\
TOTAL & 71 & 120,4531944 & & & \\
& & & & & \\
\hline & \multicolumn{7}{c}{ R-Quadrado } & C.V. & Raiz QMR & Média Pol \\
& 0,898513 & 4,498255 & 0,618073 & 13,74028 \\
\hline
\end{tabular}


Apêndice 15. Análise de variância para Brix \% cana, dentro das variedades de cana-deaçúcar testadas.

\begin{tabular}{|c|c|c|c|c|c|}
\hline Causa da Variação & G.L. & Tipo III SQ & $\begin{array}{l}\text { Quadrado } \\
\text { Médio }\end{array}$ & $\begin{array}{c}\text { Valor } \\
\text { F }\end{array}$ & $\operatorname{Pr}>F$ \\
\hline Cana & 3 & 0,53444444 & 0,17814815 & 0,38 & 0,7704 \\
\hline Resíduo (A) & 8 & 3,75333333 & 0,46916667 & & \\
\hline Ethrel & 1 & 0,00888889 & 0,00888889 & 0,02 & 0,9024 \\
\hline Cana $\mathrm{x}$ Ethrel & 3 & 1,99000000 & 0,66333333 & 1,20 & 0,3714 \\
\hline Resíduo (B) & 8 & 4,43777778 & 0,55472222 & & \\
\hline Mês & 2 & 49,21194444 & 24,60597222 & $115,08^{*}$ & 0,0001 \\
\hline Cana $x$ Mês & 6 & 3,40472222 & 0,56745370 & $2,65^{*}$ & 0,0333 \\
\hline Ethrel x Mês & 2 & 0,22027778 & 0,11013889 & 0,52 & 0,6023 \\
\hline Cana $\times$ Ethrel $\times$ Mês & 6 & 2,28083333 & 0,38013889 & 1,78 & 0,1353 \\
\hline Resíduo (C) & 32 & 6,84222222 & 0,21381944 & & \\
\hline \multirow[t]{2}{*}{ TOTAL } & 71 & 72,68444444 & & & \\
\hline & & $\begin{array}{c}\text { R-Quadrado } \\
0,905864\end{array}$ & $\begin{array}{c}\text { C.V. } \\
2,789313\end{array}$ & $\begin{array}{c}\text { Raiz QMR } \\
0,462406\end{array}$ & $\begin{array}{c}\text { Média Brix } \\
16,57778\end{array}$ \\
\hline
\end{tabular}

Apêndice 16. Análise de variância para A.R. \% cana, dentro das variedades de cana-deaçúcar testadas, sem exclusão de nenhum valor.

\begin{tabular}{lccccc}
\hline Causa da Variação & G.L. & Tipo III SQ & $\begin{array}{c}\text { Quadrado } \\
\text { Médio }\end{array}$ & $\begin{array}{c}\text { Valor } \\
\text { F }\end{array}$ & Pr > F \\
\hline Cana & 3 & 0,02313333 & 0,00771111 & 0,93 & 0,4694 \\
Resíduo (A) & 8 & 0,06631111 & 0,00828889 & & \\
Ethrel & 1 & 0,05445000 & 0,05445000 & 6,90 & 0,0303 \\
Cana x Ethrel & 3 & 0,02099444 & 0,00699815 & 0,89 & 0,4878 \\
Resíduo (B) & 8 & 0,06308889 & 0,00788611 & & \\
Mês & 2 & 2,10601944 & 1,05300972 & 311,81 & 0,0001 \\
Cana x Mês & 6 & 0,08955833 & 0,01492639 & 4,42 & 0,0323 \\
Ethrel x Mês & 2 & 0,01282500 & 0,00641250 & 1,90 & 0,1662 \\
Cana x Ethrel x Mês & 6 & 0,04813056 & 0,00802176 & 2,38 & 0,0519 \\
Resíduo (C) & 32 & 0,10806667 & 0,00337708 & & \\
TOTAL & 71 & 2,59257778 & & & \\
& \multicolumn{7}{c}{ R-Quadrado } & C.V. & Raiz QMR & Média A.R \\
\hline
\end{tabular}


Apêndice 17. Análise de variância para A.R. \% cana, dentro das variedades de cana-deaçúcar testadas, com exclusão do valor discrepante.

\begin{tabular}{lccccc}
\hline Causa da Variação & G.L. & Tipo III SQ & $\begin{array}{c}\text { Quadrado } \\
\text { Médio }\end{array}$ & $\begin{array}{c}\text { Valor } \\
\text { F }\end{array}$ & Pr $>$ F \\
\hline Cana & 3 & 0,01553270 & 0,00517757 & 0,82 & 0,5197 \\
Resíduo (A) & 8 & 0,05069111 & 0,00633639 & & \\
Ethrel & 1 & 0,06818182 & 0,06818182 & 12,55 & 0,0076 \\
Cana x Ethrel & 3 & 0,03178159 & 0,01059386 & 1,95 & 0,202 \\
Resíduo (B) & 8 & 0,0434688 & 0,00543361 & & \\
Mês & 2 & 1,86481879 & 0,93240940 & 382,00 & 0,0001 \\
Cana x Mês & 6 & 0,05072968 & 0,00845495 & 3,46 & 0,0098 \\
Ethrel x Mês & 2 & 0,01842353 & 0,00921176 & 3,77 & 0,0341 \\
Cana x Ethrel x Mês & 6 & 0,04295029 & 0,00715838 & $2,93 *$ & 0,0220 \\
Resíduo (C) & 31 & 0,07566667 & 0,0024086 & & \\
TOTAL & 70 & 2,32419718 & & & \\
& \multicolumn{7}{c}{ R-Quadrado } & C. V. & Raiz QMR & Média A.R. \\
& 0,967444 & 14,60349 & 0,449405 & 0,338310 \\
\hline
\end{tabular}

Apêndice 18. Análise de variância para Fibra \% cana, dentro das variedades de cana-deaçúcar testadas, sem exclusão de nenhum valor.

\begin{tabular}{lrrrcc}
\hline Causa da Variação & G.L. & Tipo III SQ & $\begin{array}{c}\text { Quadrado } \\
\text { Médio }\end{array}$ & $\begin{array}{c}\text { Valor } \\
\text { F }\end{array}$ & Pr $>$ F \\
\hline Cana & 3 & 25,09444444 & 8,36481481 & 4,73 & 0,0351 \\
Residuo (A) & 8 & 14,15333333 & 1,76916667 & & \\
Ethrel & 1 & 17,80055556 & 17,80055556 & 6,24 & 0,0371 \\
Cana x Ethrel & 3 & 7,44944444 & 2,48314815 & 0,87 & 0,4954 \\
Resíduo (B) & 8 & 22,82666667 & 2,85333333 & & \\
Mês & 2 & 94,08777778 & 47,04388889 & 44,24 & 0,0001 \\
Cana x Mês & 6 & 7,29888889 & 1,21648148 & 1,14 & 0,3501 \\
Ethrel x Mês & 2 & 3,86777778 & 1,93388889 & 1,82 & 0,1786 \\
Cana x Ethrel x Mês & 6 & 9,22555556 & 1,53759259 & 2,45 & 0,2282 \\
Resíduo (C) & 32 & 34,0266667 & 1,06333333 & & \\
TOTAL & 71 & 235,8311111 & & & \\
& \multicolumn{7}{c}{ R-Quadrado } & C. V. & Raiz QMR & Média Fibra \\
& 0,855716 & 8,747055 & 1,031181 & 11,78889 \\
\hline
\end{tabular}


Apêndice 19. Análise de variância para Fibra \% cana, dentro das variedades de cana-deaçúcar testadas, com exclusão do valor discrepante.

\begin{tabular}{|c|c|c|c|c|c|}
\hline Causa da Variação & G.L. & Tipo III SQ & $\begin{array}{c}\text { Quadrado } \\
\text { Médio }\end{array}$ & $\begin{array}{c}\text { Valor } \\
\mathrm{F}\end{array}$ & $\operatorname{Pr}>F$ \\
\hline Cana & 3 & 23,38787302 & 7,79595767 & 5,44 & 0,0247 \\
\hline Resíduo (A) & 8 & 11,46994444 & 1,43374306 & & \\
\hline Ethrel & 1 & 23,92757576 & 23,92757576 & 13,46 & 0,0063 \\
\hline Cana $x$ Ethrel & 3 & 4,48787302 & 1,49595767 & 0,84 & 0,5084 \\
\hline Resíduo (B) & 8 & 14,22105556 & 1,77763194 & & \\
\hline Mês & 2 & 70,85580065 & 35,42790033 & 68,19 & 0,0001 \\
\hline Cana x Mês & 6 & 7,62630117 & 1,27105019 & $2,45^{*}$ & 0,0471 \\
\hline Ethrel x Mês & 2 & 8,61235294 & 4,30617647 & $8,29^{* *}$ & 0,0013 \\
\hline Cana x Ethrel x Mês & 6 & 5,02824561 & 0,83804094 & 1,61 & 0,1768 \\
\hline Resíduo (C) & 31 & 16,1055556 & 0,5195341 & & \\
\hline \multirow[t]{2}{*}{ TOTAL } & 70 & 191,5087324 & & & \\
\hline & & $\begin{array}{c}\text { R-Quadrado } \\
0,915902\end{array}$ & $\begin{array}{c}\text { C.V. } \\
6,162799\end{array}$ & $\begin{array}{c}\text { Raiz QMR } \\
0,720787\end{array}$ & $\begin{array}{c}\text { Média Fibra } \\
11,69577\end{array}$ \\
\hline
\end{tabular}

Apêndice 20. Análise de variância para Pureza \% cana, dentro das variedades de cana-deaçúcar testadas.

\begin{tabular}{lrcccc}
\hline Causa da Variação & G.L. & Tipo III SQ & $\begin{array}{c}\text { Quadrado } \\
\text { Médio }\end{array}$ & $\begin{array}{c}\text { Valor } \\
\text { F }\end{array}$ & Pr $>$ F \\
\hline Cana & 3 & 6,65611111 & 2,21870370 & 0,27 & 0,8472 \\
Resíduo (A) & 8 & 66,3900000 & 8,2987500 & & \\
Ethrel & 1 & 5,55555556 & 5,55555556 & 0,49 & 0,5042 \\
Cana x Ethrel & 3 & 44,1722222 & 14,72407407 & 1,30 & 0,3408 \\
Resíduo (B) & 8 & 90,9122222 & 11,3640278 & & \\
Mês & 2 & 805,7544444 & 402,8772222 & $43,70^{*}$ & 0,0001 \\
Cana x Mês & 6 & 24,3088889 & 4,0514815 & 0,44 & 0,8468 \\
Ethrel x Mês & 2 & 0,2744444 & 0,1372222 & 0,01 & 0,9852 \\
Cana x Ethrel x Mês & 6 & 124,0311111 & 20,6718519 & 2,24 & 0,0643 \\
Resíduo (C) & 32 & 294,997778 & 9,218681 & & \\
TOTAL & 71 & 1463,052778 & & & \\
& \multicolumn{7}{c}{ R-Quadrado } & C.V. & Raiz QMR & Média Pureza \\
\hline
\end{tabular}


Apêndice 21. Médias mensais de precipitação em mm de chuva, referentes ao período de janeiro/94 à julho/95.

\begin{tabular}{lrr}
\hline Meses & 1994 & 1995 \\
\hline Janeiro & 4,35 & 6,36 \\
Fevereiro & 5,51 & 14,84 \\
Março & 7,18 & 6,28 \\
Abril & 3,83 & 2,86 \\
Maio & 1,81 & 2,07 \\
Junho & 1,22 & 0,78 \\
Julho & 0,80 & 1,91 \\
Agosto & 0,00 & \\
Setembro & 0,02 & \\
Outubro & 4,09 & \\
Novembro & 8,31 & \\
Dezembro & 8,41 & \\
\hline
\end{tabular}

Apêndice 22. Médias mensais de temperatura em ${ }^{\circ} \mathrm{C}$ referentes ao período de janeiro/94 à julho/95.

\begin{tabular}{|c|c|c|c|c|c|c|}
\hline & & 1994 & & & 1995 & \\
\hline Meses & Máxima & Mínima & Média & Máxima & Mínima & Média \\
\hline Janeiro & 30,29 & 19,26 & 24,78 & 31,89 & 20,56 & 26,22 \\
\hline Fevereiro & 32,97 & 20,19 & 26,58 & 29,94 & 20,01 & 24,97 \\
\hline Março & 29,66 & 18,50 & 24,08 & 30,44 & 18,48 & 24,46 \\
\hline Abril & 28,98 & 16,63 & 22,80 & 29,21 & 15,96 & 22,59 \\
\hline Maio & 26,84 & 14,98 & 20,91 & 25,94 & 13,70 & 19,82 \\
\hline Junho & 24,81 & 10,28 & 17,55 & 25,96 & 11,37 & 18,66 \\
\hline Julho & 27,00 & 10,68 & 18,84 & 26,78 & 12,87 & 19,83 \\
\hline Agosto & 28,38 & 10,96 & 19,67 & & & \\
\hline Setembro & 31,67 & 14,08 & 22,88 & & & \\
\hline Outubro & 32,15 & 18,35 & 25,25 & & & \\
\hline Novembro & 30,70 & 18,59 & 24,67 & & & \\
\hline Dezembro & 31,67 & 19,85 & 25,76 & & & \\
\hline
\end{tabular}

